EVELYN THAÍS FANTOZZI

"ESTUDO DOS MECANISMOS ENVOLVIDOS COM OS EFEITOS DO ESTRADIOL NA INFLAMAÇÃO LOCAL E SISTÊMICA EM MODELO DE ISQUEMIA E REPERFUSÃO INTESTINAL EM RATAS:

INFLUÊNCIA DO SISTEMA LINFÁTICO"

Tese apresentada ao Programa de Pós-Graduação em Farmacologia do Instituto de Ciências Biomédicas da Universidade de São Paulo, para a obtenção do Título de Doutora em Ciências.

São Paulo 


\section{"ESTUDO DOS MECANISMOS ENVOLVIDOS COM OS EFEITOS DO ESTRADIOL NA INFLAMAÇÃO LOCAL E SISTÊMICA EM MODELO DE ISQUEMIA E REPERFUSÃO INTESTINAL EM RATAS: INFLUÊNCIA DO SISTEMA LINFÁTICO"}

Tese apresentada ao Programa de Pós-Graduação em Farmacologia do Instituto de Ciências Biomédicas da Universidade de São Paulo, para a obtenção do Título de Doutora em Ciências.

Área de concentração: Farmacologia

Orientador: Prof. Dr. Wothan Tavares de Lima

Coorientadora: Dra. Ana Cristina Breithaupt Faloppa

Versão corrigida.

A versão original encontra-se disponível na Secretaria de Pós-graduação que aloja o Programa de PósGraduação.

São Paulo 


\section{CATALOGAÇÃO NA PUBLICAÇÃO (CIP) Serviço de Biblioteca e informação Biomédica do Instituto de Ciências Biomédicas da Universidade de São Paulo}

Ficha Catalográfica elaborada pelo(a) autor(a)

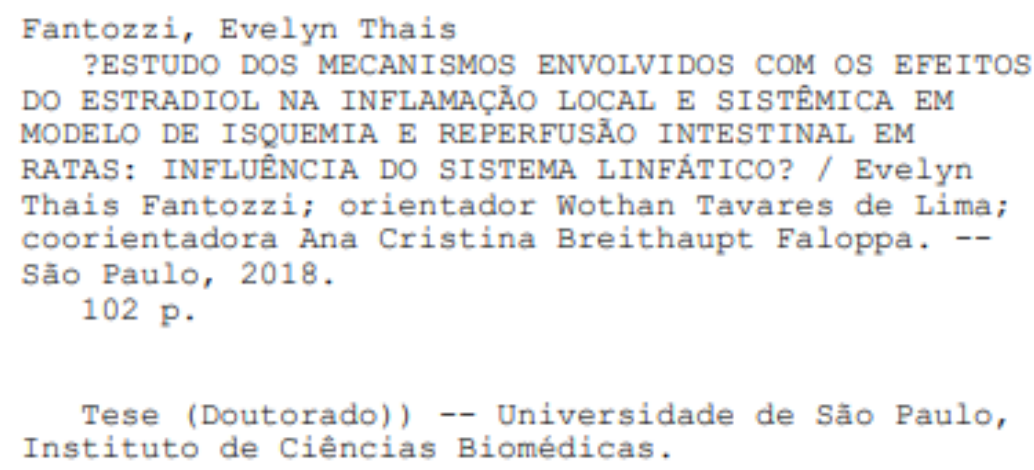

1. fêmeas. 2. IR intestinal. 3. sistema linfático. 4. neutrófilos. 5. estradiol. I. Tavares de Lima, Wothan, orientador. II. Breithaupt Faloppa, Ana Cristina, coorientador. III. Titulo. 
Candidato(a): Evelyn Thaís Fantozzi

Titulo da Tese: Estudo dos mecanismos envolvidos com os efeitos do estradiol na inflamação local e sistêmica em modelo de isquemia e reperfusão intestinal em ratas: influência do sistema linfático.

Orientador: Wothan Tavares de Lima

A Comissão Julgadora dos trabalhos de Defesa da Tese de Doutorado, em sessão publica realizada a I , considerou o(a) candidato(a):

\section{( ) Aprovado(a) ( ) Reprovado(a)}

Examinador(a):

Assinatura:

Nome:

Instituição:

Examinador(a):

Assinatura:

Nome:

Instituição:

Examinador(a):

Assinatura:

Nome:

Instituição:

Examinador(a):

Assinatura:

Nome:

Instituição:

Presidente:

Assinatura:

Nome:

Instituição: 


\section{Certificado}

Certificamos que o protocolo registrado sob $n^{\circ} \mathbf{1 1 1}$ nas fls. 10 do livro 03 para uso de animais em experimentação, sob a responsabilidade do Prof(a) $\operatorname{Dr}(\mathrm{a})$ ) Wothan Tavares de Lima, Coordenador (a) da Linha de pesquisa "Estudo da influência do gênero na contratilidade, microcirculação e geração de mediadores inflamatórios no intestino após a isquemia e reperfusão: Envolvimento do sistema linfático e de possíveis vias de sinalização" do qual participam o(s) aluno(s) Evelyn Thais Fantozzi, Fernanda Yamamoto Ricardo da Silva, Maria Beatriz Bernadez Amorin, estagiários Sara Garbin, Guilherme Henrique Gatti e os pesquisadores Bernardo Boris Vargaftig, Ricardo Martins de Oliveira Filho, Ana Cristina Breithaupt-Faloppa, está de acordo com os Princípios Éticos de Experimentação Animal adotado pela Sociedade Brasileira de Ciência de Animais de Laboratório (SBCAL) e foi aprovado pela COMISSÃO DE ÉTICA NO USO DE ANIMAIS (CEUA) em 04.11.2013, com validade de 4 anos.

São Paulo, 06 de novembro de 2013.
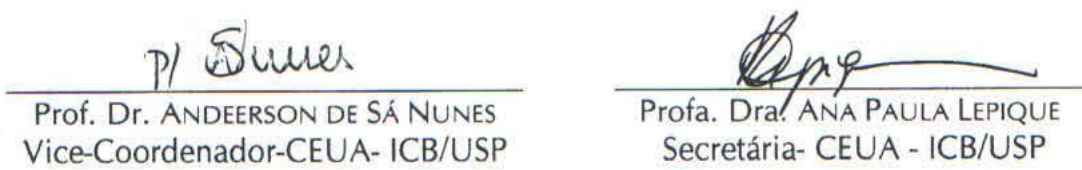
Dedico este trabalho aos meus pais, sem eles não teria condições de chegar até aqui. Com certeza o amor, carinho e força que eles me deram, unidos à fé em Deus são a minha maior base! 


\section{AGRADECIMENTOS}

Ao Wothan, mais do que um simples orientador. Agradeço por todo ensinamento, pelas conversas, incentivos, por ensinar valores éticos, morais e humanos e, principalmente por acreditar em mim. Não haveriam palavras para descrever o quanto aprendi e mudei nestes oito anos graças a sua existência em minha vida.

Ao Thor, que mesmo sendo apenas um coelhinho sempre aqueceu meu coração e alma nos momentos mais difíceis. E a Mia, meu pedacinho de alegria para trazer forças na última jornada.

Aos meus familiares e amigos por todo o suporte emocional necessário nesta longa jornada.

A Sara, uma grande amiga e irmã que tive a grande sorte de ganhar durante esta longa tese. Com certeza, não seria tão agradável sem você!

A Ana Cristina, por ser calmaria em tempos de desespero. Por ser muito mais do que uma coorientadora, uma amiga e grande exemplo.

A Yanira, por toda amizade, ajuda, conversas e orientações.

Ao Dom e a Varsha pela grande recepção e fazer de Londres uma das minhas melhores memórias.

A Fernanda, Maria Beatriz, André, Barbara, Evelyn, Martina e Sueli por tornarem a pós-graduação mais fácil e doce.

A Helory, Cida e Zilma, por todo auxilio técnico e amizade.

Ao Professor Ricardo, pelo caloroso apoio, ensinamentos e risadas.

Ao Departamento de Farmacologia por todo suporte.

Ao CNPq (870212/1997-4) e a FAPESP (2013/15291-0) pelo suporte financeiro.

O presente trabalho foi realizado com apoio da Coordenação de Aperfeiçoamento de Pessoal de Nível Superior - Brasil (CAPES) - Código de Financiamento 001.

Sou muito grata a todos e tudo que passaram pela minha jornada como doutoranda, é uma experiência única que carrego com muito carinho. 
"Havia um homem que costumava ter em cima de sua cama uma placa escrita: ISSO TAMBÉM PASSA...

Então perguntaram à ele o por quê disso.

Ele disse que era para se lembrar que, quando estivesse passando por momentos ruins, poder se lembrar de que eles iriam embora, e que ele teria que passar por aquilo por algum motivo.

Mas essa placa também era para lembrá-lo que quando estivesse muito feliz, que não deixasse tudo pra trás, porque esses momentos também iriam passar e momentos difíceis viriam de novo. E é exatamente disso que a vida é feita: MOMENTOS!

Momentos os quais temos que passar, sendo bons ou não, para o nosso próprio aprendizado. Por algum motivo, nunca esqueça do mais importante: NADA É POR ACASO! Absolutamente nada.

Por isso temos que nos preocupar em fazer a nossa parte da melhor forma possível." 


\section{RESUMO}

FANTOZZI, E. T. Estudo dos mecanismos envolvidos com os efeitos do estradiol na inflamação local e sistêmica em modelo de isquemia e reperfusão intestinal em ratas: influência do sistema linfático. 2018. 102 f. Tese (Doutorado em: Farmacologia) - Instituto de Ciências Biomédicas, Universidade de São Paulo, São Paulo, 2018.

A isquemia intestinal pode decorrer da obstrução do fluxo da artéria mesentérica superior que, em humanos, supre o pâncreas, parte do cólon e o intestino delgado. A geração de produtos tóxicos durante o período de isquemia faz com que a reperfusão intestinal gere lesão em órgãos distantes do local onde a isquemia ocorreu. Estudos consideram que essas lesões são moduladas por mediadores inflamatórios derivados do trato gastrintestinal drenados pelo sistema circulatório e também o sistema linfático mesentérico. Visto que existem evidências de diferenças de suscetibilidade de resposta imune entre gêneros e que terapias específicas para prevenção ou tratamento das lesões teciduais causadas pela IR intestinal ainda não estão disponíveis. Então, a investigação dos efeitos da IR intestinal sobre o intestino, como sua capacidade de gerar mediadores inflamatórios em fêmeas reveste-se de importância adicional, mormente levando-se em consideração o papel do sistema linfático como transportador de citocinas e células considerando o efeito protetor do estradiol. Os resultados deste relatório mostram que fêmeas com ovários removidos apresentam maior inflamação local e sistêmica após a IR intestinal caracterizada pelo aumento de permeabilidade macromolecular e vascular intestinal, recrutamento de leucócitos, principalmente neutrófilos, e geração de mediadores inflamatórios quando comparado com o grupo de animais com ovários intactos. Os tratamentos com estradiol, $24 \mathrm{~h}$ antes da IR intestinal ou 30 minutos após o início da isquemia, exerceram funções protetoras distintas e dependentes do momento de sua administração. Os estudos da participação do sistema linfático na modulação da resposta inflamatória intestinal após a IR sugerem que em fêmeas, a obstrução do fluxo linfático durante o evento isquêmico intestinal pode ser lesiva. Por fim, os dados apresentados no presente relatório reforçam a idéia do intestino como o "motor" da inflamação na vigência da IR intestinal e, é possível que o estradiol exerça algum controle sobre os componentes da linfa drenada.

Palavras chave: fêmeas, IR intestinal, sistema linfático, neutrófilos, estradiol. 


\begin{abstract}
FANTOZZI, E. T. Study of the mechanisms involved with the estradiol effects on local and systemic inflammation in intestinal ischemia and reperfusion model in female rats: influence of the lymphatic system. 2018. 102 p. P.h.D. these (Pharmacology) - Biomedical Science Institute, University of Sao Paulo, Sao Paulo, 2018.
\end{abstract}

Intestinal ischemia reperfusion results from obstruction of the superior artery flow, wich in humans, supplies the pancreas, parto $f$ the colon and the small intestine. In reperfusion period the generation of toxic products during the ischemia cause injuryto organs distant fromthe site where ischemia occurred. Studies consider that such dysfunctions are modulated by the circulatory and mesenteric lympatich systems. Since there are evidences of diferences in susceptibility of the imune response between genders, specific therapies for the prevention or treatment of tissue damage caused by intestinal IR are not yet available. Therefore, the investigation of the effects generated by intestinal IR on the intestine, such as its ability to generate inflammatory mediators in females, is of additional importance, especially considering the role of the lymphatic system as a carrier of cytokines and cells adding the protective effect of estradiol. The results of this report show that females with removed ovaries presente higher local and systemic inflammation after intestinal IR characterized by increased macromolecular and vascular permeability, recruitment of leukocytes, mainly neutrophils, and generation of inflammatory mediators when compared to the group of animals with intact ovaries. Treatments with estradiol, $24 \mathrm{~h}$ prior to intestinal IR or 30 min after onset ischemia, exerted differents protectives functions depending on the moment of its administration. Studies around the involvement of lymphatic systemic in the modulation of inflammatory response after intestinal IR suggest the in females, the obstruction of lymphatic flow during the intestinal ischemic eventmay be harmful. Finally, the data presented in this report reinforce the idea of the gut as the "motor" of inflammation during intestinal IR, and it is possible that estradiol exerts some control over the componentes of the drained lymph.

Keywords: female rats, intestinal IR, lymphatic system, neutrophils, estradiol. 


\section{SUMÁRIO}

1 INTRODUÇÃO

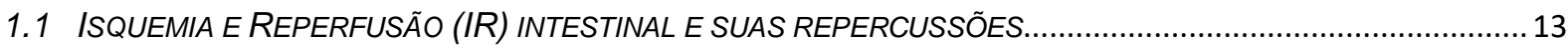

1.2 PAPEL DO SISTEMA LINFÁTICO NA INFLAMAÇÃO GERADA PELA IR INTESTINAL ......................................... 15

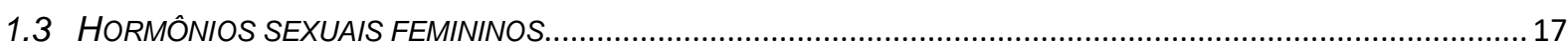

2 OBJETIVOS

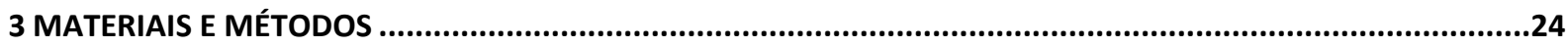

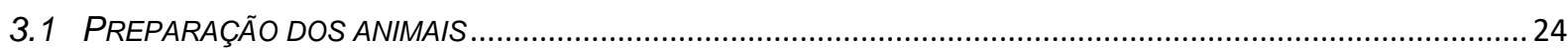

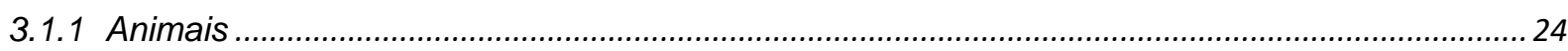

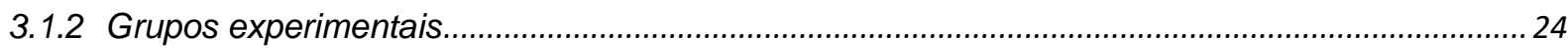

Os animais foram subdivididos em 6 grupos com as seguintes características:.....................................24

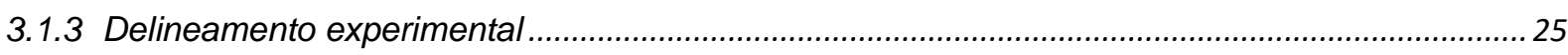

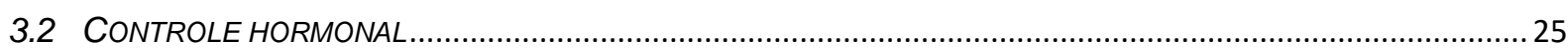

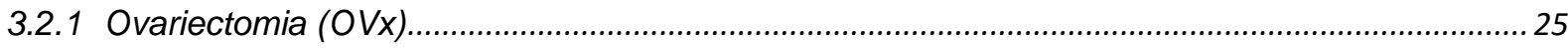

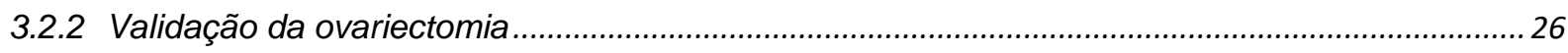

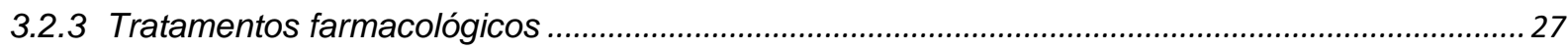

3.2.4 Determinação dos níveis séricos de estradiol.......................................................................... 27

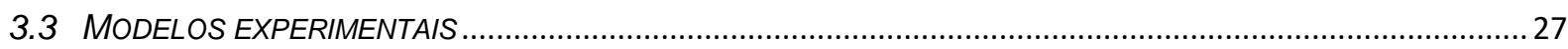

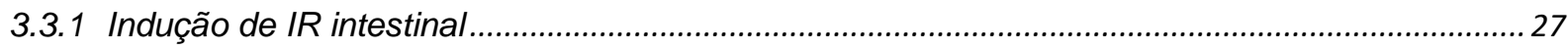

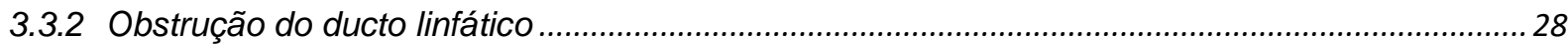

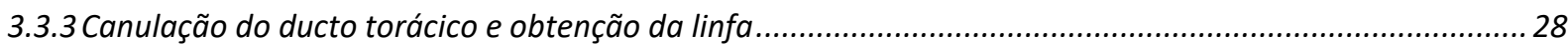

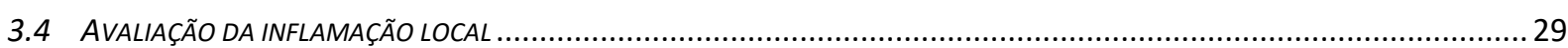

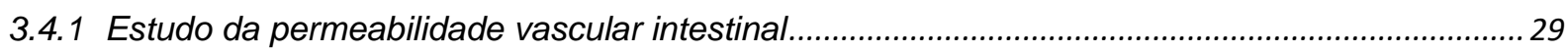

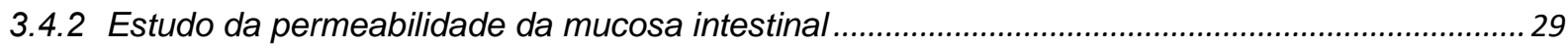

3.4.3 Estudo do recrutamento/ativação de neutrófilos no intestino.........................................................2 29

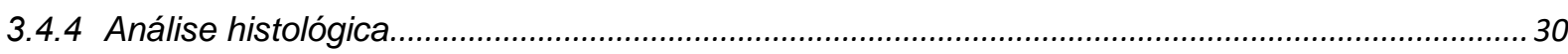

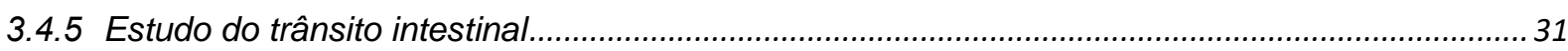

3.4.6 Coleta e análise do fluido intestinal obtido durante a IR intestinal: ................................................ 31

3.4.7 Determinação dos níveis de interleucina-10 (IL-10) e CINC-1 no fluido intestinal obtido durante

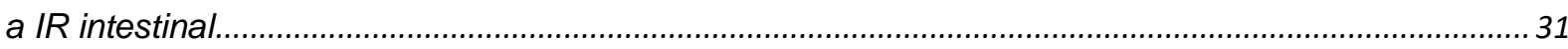

3.4.8 Perfil genético inflamatório e da sinalização receptores do estradiol do mesentério por PCR

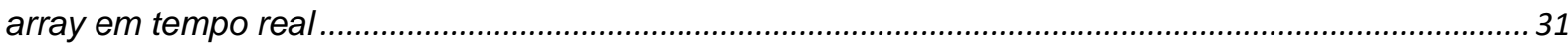

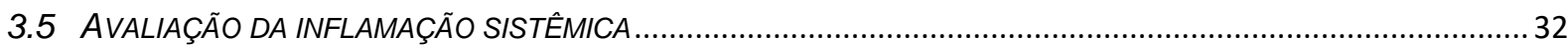

3.5.1 Determinação número total e diferencial de leucócitos e do número de plaquetas circulantes.. 32

3.5.2 Determinação do número total de células na medula óssea............................................................ 32

3.5.3 Ensaio de quimiotaxia in vitro com neutrófilos circulantes................................................................ 32 


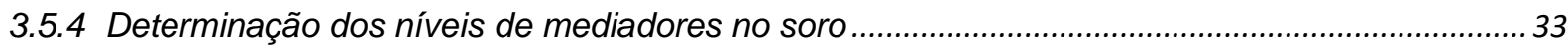

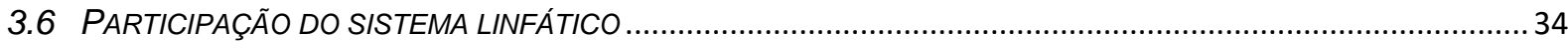

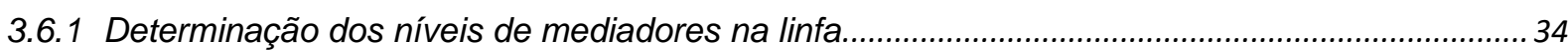

3.6.2 Determinação do volume e número total de leucócitos presentes na linfa ..................................... 34

3.6.3 Identificação das células presentes na linfa por citometria de fluxo.............................................. 34

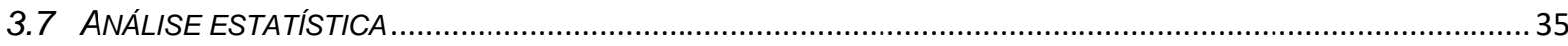

4 RESULTADOS.

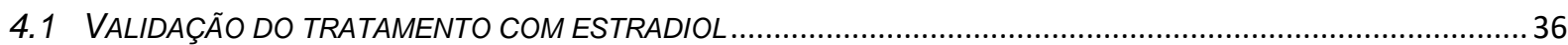

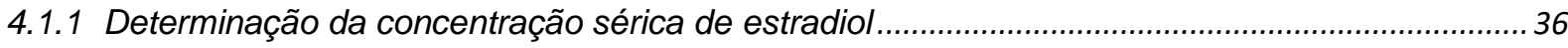

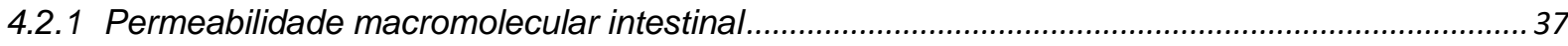

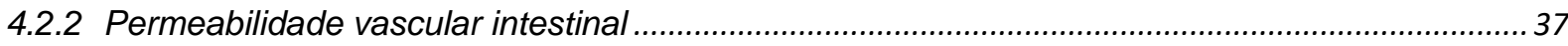

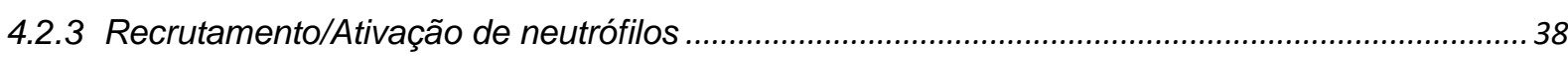

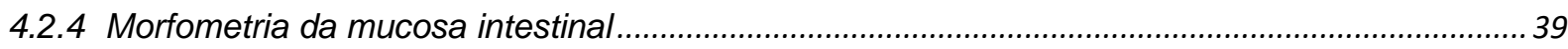

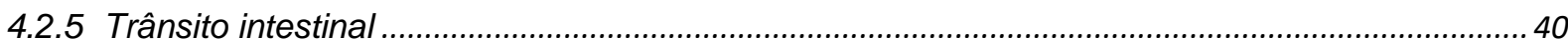

4.2.6 Estudo do fluido intestinal gerado durante a IR intestinal .............................................................. 41

4.2.7 Perfil gênico inflamatório e da sinalização induzida pelo estradiol no mesentério......................... 44

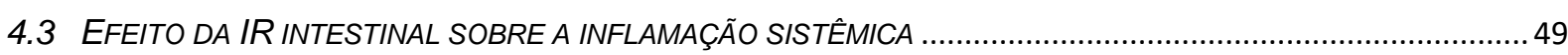

4.3.1 Número de leucócitos e plaquetas circulantes .......................................................................... 49

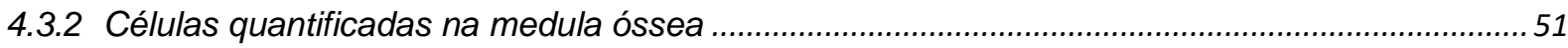

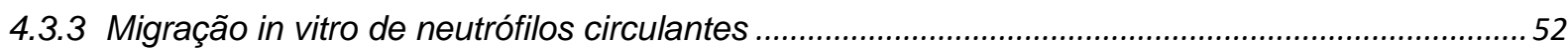

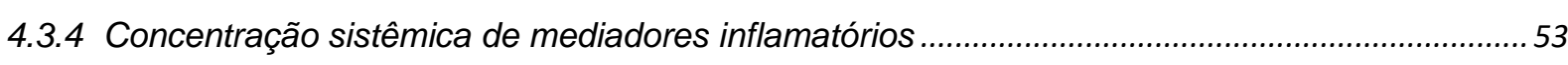

4.4 EFEITO DA OBSTRUÇÃO DO FLUXO DO DUCTO LINFÁTICO SOBRE A IR INTESTINAL......................................58

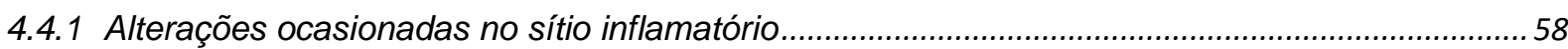

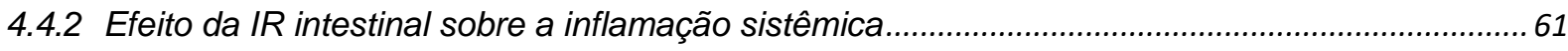

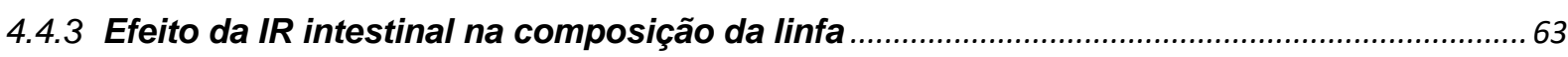

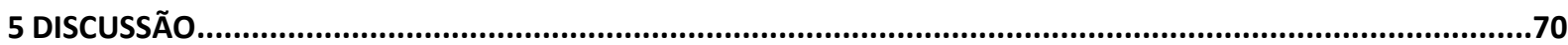

5.1 EFEITO DO ESTRADIOL NA INFLAMAÇÃO LOCAL CAUSADA PELA IR INTESTINAL ........................................ 70

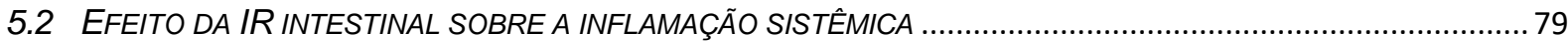

5.3 EFEITO DA OBSTRUÇÃO DO DUCTO LINFÁTICO SOBRE A IR INTESTINAL.................................................. 84

6 CONCLUSÃO

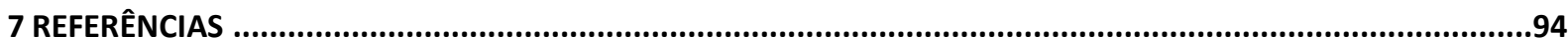




\section{INTRODUÇÃO}

\subsection{Isquemia e Reperfusão (IR) intestinal e suas repercussões}

A isquemia é definida como a obstrução do suprimento de sangue e de oxigênio para um determinado órgão por diminuição da luz de artérias, arteríolas ou capilares. Por consequência, este órgão sofre diversas alterações do metabolismo, resultando no acúmulo de metabólitos tóxicos, redução de reservas energéticas e eventualmente necrose tecidual (KALOGERIS et al., 2016; SCARABELLI et al., 2002). A obstrução do fluxo da artéria mesentérica superior (AMS) é considerada como um evento isquêmico com alto potencial lesivo. Em humanos, a AMS é responsável pelo suprimento de sangue para o pâncreas, parte do cólon e principalmente o intestino delgado como pode ser observado na figura 1. Vale ressaltar que a circulação esplâncnica representa $75 \%$ do volume sanguíneo do organismo, justificando, portanto, que a obstrução da AMS cause profundos efeitos deletérios sobre a homeostasia da região esplâncnica (VOLLMAR; MENGER, 2011).

Figura 1 - A artéria mesentérica superior e seus ramos. Observe que esta artéria irriga o intestino, desde a metade inferior da porção descendente do duodeno até o terço distal do cólon transverso (indicado pela seta).

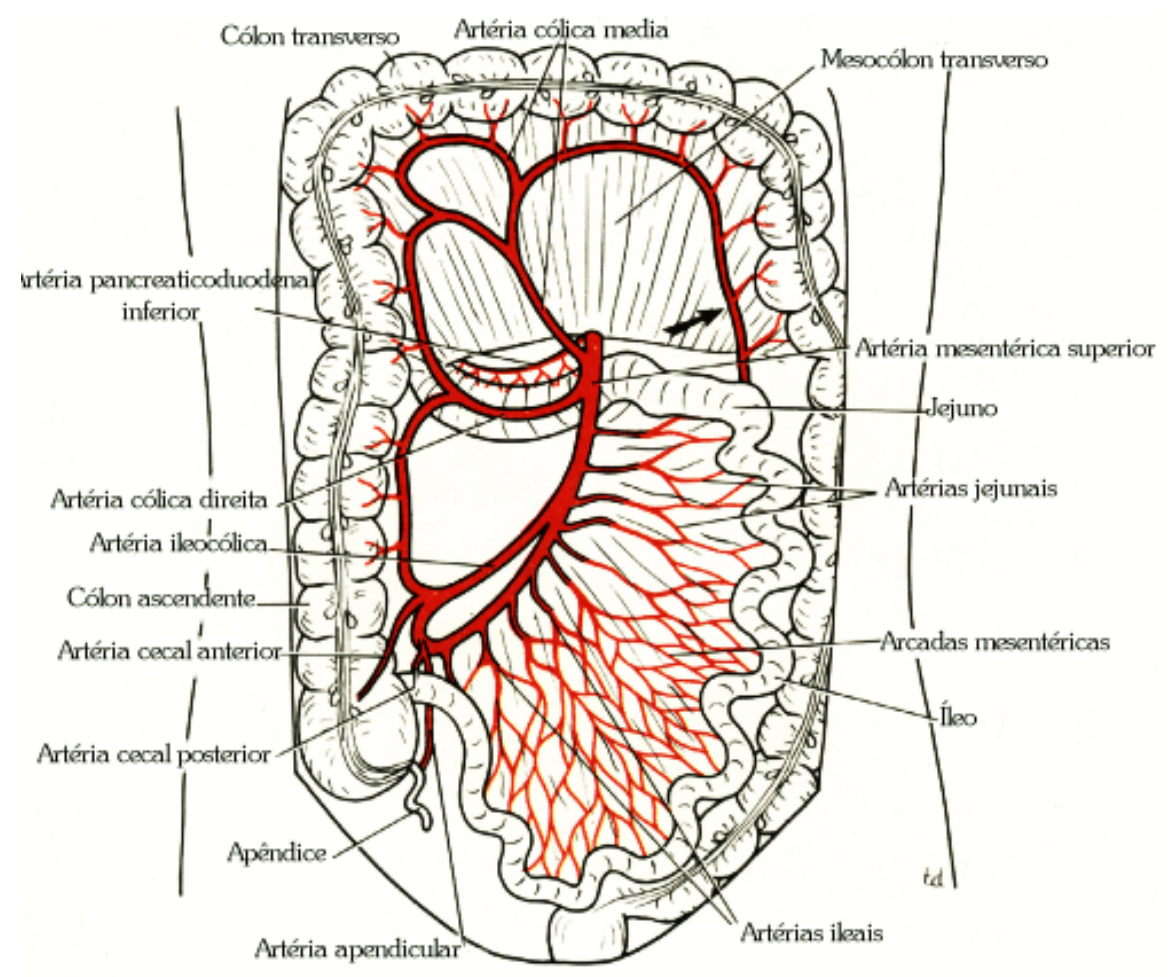

Fonte: SNELL (1984). 
A oclusão da AMS produz uma isquemia com intensidade gradiente ao longo do intestino. Sendo mais severa na região do intestino delgado e a porção inicial do intestino grosso (RAMOS et al., 2016; CERQUEIRA et al., 2005). A IR intestinal afeta as ligações entre as células epiteliais da mucosa intestinal, o que pode permitir o deslocamento de bactérias ou toxinas do lúmen intestinal para o espaço intersticial e, posteriormente, para a circulação sanguínea e linfática. (KINROSS et al., 2009; SOUZA et al., 2004).

Ainda não está totalmente esclarecido se apenas a isquemia, ou se em associação à reperfusão, é condição suficiente para a indução de lesão tecidual. De fato, a hipóxia tecidual e a redução de nutrientes causadas pela isquemia levam ao dano celular, sendo que a posterior fase de reperfusão pode ser considerada como fator de contribuição para a ativação celular possivelmente causada pela disseminação de produtos tóxicos e mediadores inflamatórios gerados durante a isquemia (SITUMORANG; SHEERIN, 2018).

Com respeito à hipóxia causada pela isquemia intestinal, existem dados indicando que durante esta condição ocorre a geração e ativação de amplo espectro de mediadores inflamatórios. No intestino é sabido que ocorre a ativação do fator nuclear kappa B (NF-KB) nas células do epitélio intestinal. Como resultado desta ativação pode ocorrer nova onda de geração de citocinas, entre elas o fator de necrose tumoral tipo alfa (TNF- $\alpha$ ). No contexto dos efeitos do TNF- $\alpha$, sabe-se que a concentração desta citocina pode se elevar no soro, acumular na mucosa intestinal e estimular a apoptose das células do epitélio do intestino (CHEN et al., 2003). Contudo, o período de reperfusão parece ser também crucial para o desenvolvimento de lesão tecidual no intestino. Estudos conduzidos por Parks e Granger (1986) mostraram que o intestino de animais submetidos a $3 \mathrm{~h}$ de isquemia e $1 \mathrm{~h}$ de reperfusão se torna mais comprometido que o intestino de animais submetidos somente à isquemia (neste caso de $4 \mathrm{~h}$ ) por meio da análise da lesão das vilosidades intestinais. Estes achados foram explicados considerando a geração de espécies reativas de oxigênio que, quando em excesso geram estresse oxidativo celular, disfunção mitocondrial e, iniciam o processo de morte celular (ZHOU et al., 2018). Admite-se que esses radicais são gerados durante a hipóxia e disseminados sistemicamente quando ocorre estabelecimento da reperfusão, isto é, quando o sangue retorna a circular no intestino (CADENAS, 2018). Nestas condições poderia ocorrer a ativação e adesão de leucócitos ao endotélio 
vascular (STURTZEL, 2017). Em consequência há aumento de permeabilidade microvascular, perda da integridade endotelial, formação de edema intersticial com aumento da pressão intersticial. Tal aumento de pressão não permite que o conteúdo microvascular retorne ao vaso gerando, assim, hemoconcentração, trombose, disfunção vasomotora, alteração das células endoteliais e edema (MENGER et al., 1997).

Portanto, as alterações microcirculatórias causadas pela IR no intestino são elementos importantes para as repercussões locais e sistêmicas da IR intestinal (VOLLMAR; MENGER, 2011). Ainda no contexto das alterações teciduais no intestino é interessante notar que o desencadeamento da lesão intestinal é precedido por alterações funcionais da microcirculação mesentérica. Tais alterações ocorrem durante períodos de hipoperfusão que se sobrepõem aos mecanismos compensatórios intestinais que mantém a homeostasia (BULKLEY et al., 1985). Existem estudos caracterizando topograficamente a região submucosa como sendo a mais sensível à falência da perfusão da parede intestinal (BEUK et al., 2000). Quando não ocorre a restauração completa do fluxo sanguíneo intestinal observa-se disfunção epitelial e endotelial, além de aumento de permeabilidade microvascular e intestinal (GUAN et al., 2009). Assim, embora possa ser paradoxal, ainda que a reperfusão seja essencial para controlar os efeitos deletérios da isquemia, ela pode ser considerada fator de contribuição para a lesão intestinal. $O$ aumento da permeabilidade microvascular intestinal está associado com falência múltipla de órgãos, aumento na incidência de complicações e morte em pacientes críticos (PEOC'H et al., 2018; DE JONG et al., 2016).

\subsection{Papel do sistema linfático na inflamação gerada pela IR intestinal}

Uma vez que a homeostase intestinal é abalada pela IR intestinal pode-se observar a progressão da inflamação sistêmica, podendo culminar na falência múltipla de órgãos e óbito. Dentre os eventos, observa-se a hipoperfusão, alteração da motilidade e quebra da barreira intestinal com translocação de conteúdos presentes no lúmen. Devido à ruptura da barreira intestinal, também observamos a invasão de patógenos e células circulantes bem como, o encaminhamento do processo inflamatório para outros órgãos como fígado, pâncreas e pulmão, o que resultará na exacerbação da resposta imune local e sistêmica (DE JONG et al., 2016). Estudos 
consideram que a disfunção pulmonar, a inflamação sistêmica e a insuficiência múltipla de órgãos e sistemas (IMOS) são parcialmente decorrentes dos efeitos dos mediadores inflamatórios derivados do trato gastrintestinal drenados pelo sistema linfático mesentérico (DEITCH et al., 2001; MAGNOTTI et al., 1998; MAGNOTTI et al., 1999). Por causa disso, considera-se que a microcirculação mesentérica exerça relevante papel sobre a inflamação sistêmica e por extensão no estado funcional de fagócitos envolvidos com a inflamação (DEITCH et al., 1994; SHENKAR et al., 1994; WELBORN et al., 2000).

Essencialmente, o sistema linfático, além de regular o balanço fluídico tecidual é uma das principais vias de transporte de células do sistema imunológico. Nesta linha de pensamento e dentro do contexto da drenagem linfática intestinal, vale lembrar que o pulmão é o primeiro órgão exposto à linfa mesentérica. Desta forma, a qualidade do conteúdo da linfa pode interferir com a homeostasia do pulmão. Assim, em modelo de inflamação pulmonar causada por choque hemorrágico experimental, condição que induz o estabelecimento de isquemia intestinal ao longo do tempo, os estudos de Magnotti et al. (1998), mostraram que a inflamação pulmonar depende de fatores humorais contidos na linfa mesentérica intestinal.

Estudos do nosso laboratório revelam importante participação da linfa nas repercussões pulmonares da IR intestinal (BREITHAUPT-FALOPPA et al., 2012; BREITHAUPT-FALOPPA et al., 2009; CAVRIANI et al., 2007; COELHO et al., 2007; CAVRIANI et al., 2005). Ainda, a linfa proveniente do leito mesentérico é rica em citocinas e eicosanoides (BREITHAUPT-FALOPPA et al., 2012; CAVRIANI et al., 2007). A obstrução do fluxo linfático leva à redução da inflamação pulmonar, inflamação sistêmica, e da permeabilidade microvascular intestinal (CAVRIANI et al., 2005). A partir desses dados, estabelecemos uma hipótese segundo a qual o intestino e pulmão comunicam-se, por meios de células e mediadores transportados pela linfa. Desta interação advém a inflamação pulmonar e a inflamação sistêmica que, adicionalmente, pode afetar mais órgãos e sistemas. De fato, a obstrução do ducto linfático, em animais IR intestinal com período de reperfusão de 2 horas, reduz não só o recrutamento de neutrófilos no pulmão, como também a permeabilidade vascular (CAVRIANI et al., 2005), e a reatividade brônquica (COELHO et al., 2007). Além disso, a linfa desses animais contém níveis elevados de citocinas (BREITHAUPT-FALOPPA et al., 2009; CAVRIANI et al., 2007). Em conjunto, os dados permitem inferir que em 
ratos, o intestino, após a lesão isquêmica e a reperfusão, mantém um estado próreativo gerando mediadores inflamatórios os quais são transportados pelo sistema linfático. Vale ressaltar que de forma geral os nossos dados (CAVRIANI et al., 2005) e de outros (HE et al., 2012) mostram que a obstrução do fluxo linfático exerce efeito

protetor sobre as repercussões inflamatórias intestinais e sistêmicas. É digno de nota que neste contexto o papel do sistema linfático difere entre os gêneros. De fato, nossos estudos preliminares, conduzidos em ratas com o fluxo linfático torácico interrompido, revelaram que tal obstrução, diferentemente do observado nos ratos machos, exacerba a inflamação pulmonar e intestinal após a IR intestinal (dados não publicados). No conjunto, sugerimos que a resposta local à IR intestinal pode ser modulada pelos hormônios sexuais femininos.

\subsection{Hormônios sexuais femininos}

Embora existam evidências de que o perfil dominante da resposta imune (Th1 ou Th2) dependa da variação hormonal durante o ciclo sexual feminino e que a modulação da resposta imune (inata e adaptativa) difira entre homens e mulheres, o dimorfismo sexual não recebe atenção merecida como fator para o entendimento dessas diferenças (FISH, 2008). Assim, estudos que visem a esclarecer qual o efeito ou ações dos hormônios sexuais femininos nesses perfis são de interesse.

De acordo com Fish (2008), o perfil Th1 da resposta tende a ser dominante durante a menstruação e na fase lútea do ciclo sexual. Por outro lado, na fase folicular, o padrão Th2 se sobrepõe ao Th1. Com esta percepção sugere-se que os hormônios sexuais femininos, ao exercerem atividade moduladora do sistema imune, podem interferir com o curso da resposta inflamatória. De fato, estudos clínicos revelam que mulheres apresentam menor incidência de pneumonia, sepse e falência de múltiplos órgãos em relação a homens (SINGH, et al., 2018; KNOOP et al., 2017; SPERRY et al., 2008; DEITCH et al., 2007).

São vários os estudos que relatam a participação dos hormônios sexuais femininos na mediação das repercussões causadas pelo trauma seguido de choque hemorrágico (FRINK et al., 2007; MOENINPOUR et al., 2007; ANGELE et al., 2006; HILDEBRAND et al., 2006; MELDRUM, 2006; CHAUDRY et al., 2003; KNÖFERL et al., 2001; KNÖFERL et al., 2002; ANGELE et al., 2000). Por exemplo, Moeninpour et al. (2007) observaram que após o trauma seguido de choque hemorrágico, o estradiol 
normaliza a expressão do receptor toll-like 4 reduzindo a inflamação dos queratinócitos epidérmicos. Já os estudos de Knöferl et al. (2001) mostram que uma única dose de estradiol previne a lesão peritoneal e do baço após choque seguido por trauma hemorrágico.

Evidências clínicas mostram que mulheres sob trauma intestinal geram menores concentrações séricas de citocinas inflamatórias e que isso reduz o índice de falência múltipla de órgãos (FRINK et al., 2007). É interessante notar que em modelo experimental de choque hemorrágico, roedores machos, sob tratamento com estradiol desenvolvem lesões menos intensas (DEITCH et al., 2001). Nesse contexto, fêmeas também preservam melhor os parâmetros hemodinâmicos após o choque hemorrágico (DEITCH et al., 2008a; DEITCH et al., 2008b). De acordo com estes autores é possível que o estradiol exerça efeitos protetores por meio da preservação da circulação sanguínea intestinal.

Estudos conduzidos por Cavriani et al. (2005), revelaram que a obstrução do fluxo linfático atenua a inflamação pulmonar causada pela IR intestinal em ratos. Assim, no contexto dos resultados obtidos em machos, é possível que os efeitos nocivos da hipoperfusão intestinal sobre a inflamação pulmonar sejam menos intensos por causa de uma maior proteção ao trauma da isquemia seguida por reperfusão do leito intestinal em gerar mediadores inflamatórios. A percepção é que os mediadores inflamatórios gerados no intestino são transportados pela linfa até os pulmões, e por causa disso medeiam a inflamação pulmonar aguda (ADAMS et al., 2000). Assim, uma hipótese que poderia ser levantada é que os hormônios sexuais femininos podem exercer papel modulador relevante no compartimento intestinal, minimizando a geração de mediadores e a ativação de células inflamatórias que seriam transportados pelo sistema linfático. Desta forma, poderiam controlar o desencadeamento das lesões em órgãos distantes do local de origem do trauma intestinal (ANANTHAKRISHNAN et al., 2005).

Os efeitos dos hormônios sexuais femininos resultam primariamente da sua interação com receptores localizados em diversos tecidos e células. Com respeito ao estradiol, os receptores clássicos para este esteroide são classificados em a e $\beta$. Tais receptores podem ser encontrados na membrana celular ou no núcleo. Além destes, um receptor ligado a proteína G (GPER) também foi descrito (PROSSNITZ et al., 2008; REVANKAR et al., 2005; THOMAS et al., 2005). Admite-se que este receptor 
seja crucial para que respostas biológicas do estradiol sejam geradas rapidamente (FILARDO et al., 2000; FILARDO et al., 2011; MAGGIOLINI et al., 2004). De forma geral, a interação do estradiol com seu receptor causa ativação seguida por uma dimerização, que aumenta sua afinidade com o DNA. Ao se ligar ao DNA, o complexo receptor+DNA recruta uma cascata de co-ativadores e proteínas para a região promotora dos genes-alvo. Este tipo de interação do hormônio com o DNA é chamado de via genômica (O'LONE et al., 2004). Alguns efeitos do estradiol, como por exemplo sua ação protetora na disfunção cardíaca após isquemia, ocorrem por mecanismo não genômico (FUKUMOTO et al., 2013). Tais efeitos ocorrem minutos após sua administração, e possivelmente não envolvem transcrição e síntese de proteínas (MEYER et al., 2006).

Embora ainda não totalmente elucidada, a distribuição dos receptores de estradiol no intestino e no pulmão é heterogênea. Neste contexto, existem relatos de que em modelo de trauma seguido de choque hemorrágico, os receptores do subtipo $\alpha$ e $\beta$ medeiam os efeitos protetores do estradiol no intestino enquanto no pulmão somente os receptores do subtipo $\beta$ modulam suas ações protetoras (YU \& CHAUDRY, 2009).

Tomados em conjunto, os estudos indicam que os hormônios sexuais femininos podem interferir com o curso da resposta inflamatória além de exercer importante efeito na homeostasia. Todavia, ainda não existem dados conclusivos acerca do papel desses hormônios sobre a inflamação intestinal causada pelo evento isquêmico intestinal ou se os hormônios sexuais afetam a capacidade do intestino de gerar mediadores inflamatórios. Portanto, os mediadores gerados no intestino durante a isquemia, na reperfusão podem ter acesso ao pulmão e interferir, por exemplo, na interação leucócito-endotélio, na modulação da atividade das células do sistema imune, na alteração da matriz extracelular e na geração adicional de mediadores inflamatórios. Desta forma, o estudo do processo inflamatório intestinal e a produção desses fatores em fêmeas pode contribuir para a compreensão dos efeitos dos hormônios sexuais femininos na manutenção da homeostasia pulmonar. Uma possibilidade é que a geração de mediadores inflamatórios e a consequente lesão intestinal causada pela IR pode ser modulada pelos hormônios sexuais femininos. De fato, existem evidências de que o estradiol aumenta a produção de óxido nítrico (NO) por meio do aumento da expressão da óxido nítrico sintase constitutiva (cNOS) no 
sistema cardiovascular (MENDELSOHN \& KARAS, 1999). Vale lembrar que estudos em andamento do nosso grupo revelam efeito protetor do estrógeno sobre o aumento de permeabilidade microvascular pulmonar em ratos após a IR intestinal. Tal efeito decorre do aumento da expressão da óxido nítrico sintase endotelial (eNOS) (BREITHAUPT-FALOPPA et al., 2013). Ainda, considerando os efeitos do NO sobre o tônus da musculatura lisa vascular, a interação do estradiol com o NO pode ter relevância adicional para a homeostasia do sistema cardiovascular (HOGG et al., 2012).

Na microcirculação pulmonar na vigência da IR intestinal, além de seus efeitos sobre a permeabilidade vascular, o estradiol também medeia a adesão de leucócitos por interferir na expressão de ICAM e VCAM (FANTOZZI, 2013). Portanto, a repercussão da IR intestinal no intestino pode ser minimizada por influência do estradiol, justificando, desta forma, a menor magnitude da resposta inflamatória observada em ratas submetidas à IR intestinal (dados preliminares do nosso laboratório). De fato, estudos em andamento em nosso laboratório confirmam que fêmeas com ovários intactos (portanto com concentrações circulantes fisiológicas dos hormônios sexuais) são mais resistentes a desenvolver a lesão intestinal por causa da isquemia como já sugerido por autores como Deitch et al. (2008a). Estes autores usando modelo de choque hemorrágico mostraram que fêmeas apresentam menor lesão intestinal quando comparadas aos machos.

Contudo, fêmeas com ovários removidos isto é, na ausência ou redução significativa dos hormônios sexuais femininos exibem exacerbação da inflamação sistêmica. Neste estudo os autores concluíram que a inflamação pulmonar causada é mediada pela lesão intestinal e que fatores tóxicos carregados pela linfa mesentérica exercem papel relevante na lesão pulmonar.

Outro ponto importante a ser considerado é que o estradiol estimula a imunidade celular e humoral (GROSSMAN, 1985; MAY, 2007), reduz a síntese de quimiocinas e medeia a quimiotaxia de neutrófilos (DOUCET et al., 2010; MIYAGI et al., 1992; SHEH et al., 2011). Desta forma, é bem razoável supor que o estradiol exerça efeitos importantes sobre o recrutamento neutrofílico. Dados experimentais obtidos em modelo de choque hemorrágico mostram efeitos protetores cardíacos e hepáticos do estradiol e da progesterona (JARRAR et al., 2000). Estes autores preconizam o uso destes esteroides como agentes terapêuticos em mulheres 
ovariectomizadas ou na pós-menopausa e que tenham sofrido choque hemorrágico. Além disto, o estradiol reduz a expressão de fatores de transcrição envolvidos na resposta inflamatória, como o NF-kB e proteína ativadora 1 (AP-1) após o choque hemorrágico experimental (SUZUKI et al., 2007).

A interação do estradiol com o sistema gastrintestinal pode também ser identificada na medida em que existem estudos indicando que a prevalência de úlcera duodenal em mulheres é menor do que em homens (LAM et al., 1994; SCHABOWSKI \& PITERA, 2004; WU et al., 2008). Neste sentido, Tuo et al., (2012) demonstraram que a secreção de bicarbonato estimulada por prostaglandina $E$ tipo 2 ( $\left.\mathrm{PGE}_{2}\right)$ é modulada por concentrações fisiológicas de estradiol, notadamente após ativar os receptores $\alpha$. Sharawy et al. (2013) relataram diferentes efeitos da ativação dos receptores de estradiol tipos $\alpha$ e $\beta$ sobre a adesão e rolamento de leucócitos e da perfusão capilar intestinal em modelo experimental de sepse. É notável que em modelo de trauma hemorrágico, o estradiol medeia a geração de óxido nítrico no intestino. Neste sentido, a ativação seletiva dos receptores $\beta$ reduz a expressão de óxido nítrico sintase induzida (iNOS) (DOUCET et al., 2010). Ainda, Sharawy et al. (2013), sugerem que o estradiol pode exercer efeitos protetores na microcirculação intestinal ao restabelecer a atividade de óxido nítrico sintase endotelial (eNOS) e reduzir a da iNOS. Apesar do mencionado, estudos adicionais sobre a interação óxido nítrico com o estradiol e seus receptores são necessários para compreender diferenças de respostas obtidas após a expressão de receptores $\alpha$ ou $\beta$ em modelo de lesão intestinal. A percepção desta necessidade é reforçada pelas discrepâncias entre dados obtidos experimental e clinicamente acerca dos efeitos protetores/deletérios do estradiol em mulheres portadoras de pneumonia ou choque hemorrágico (DIEBEL \& LIBERATI, 2011; SPERRY et al., 2008; GANNON et al., 2002; RAPPOLD et al., 2002). Talvez estas diferenças possam ser decorrentes do momento em que o estradiol é utilizado. De fato, aparentemente os efeitos do estradiol (protetores/deletérios) parecem ser dependentes da fase em que a inflamação sistêmica decorrente do choque se encontra isto é, se aguda, este esteroide exerceria efeito protetor e o efeito seria deletério só na fase mais tardia. É interessante que em estudo envolvendo 991 pacientes internados em UTIs, (75\% do sexo masculino) houve correlação entre elevadas concentrações no soro de estradiol e morte decorrente de trauma (DOSSETT et al., 2008). Os estudos mencionados reforçam a 
visão de que os efeitos do estradiol podem ser protetores ou lesivos e que existem diferenças de sua atividade entre os gêneros. Além disso, fica evidenciado que apesar da compreensão de sua participação na resposta inflamatória após o trauma, ainda não se conhece com clareza os mecanismos reguladores desses efeitos. Ainda, o risco de pacientes internados por causa de trauma serem portadores de infecção nosocomial é maior em homens do que em mulheres. E mais, o trauma eleva o risco de morte de pacientes homens portadores de infecção nosocomial (GANON et al., 2004).

Tomados em conjunto os dados apresentados indicam que o estradiol pode interferir com o curso da resposta inflamatória e exercer importante efeito (positivo/negativo) na homeostasia. Todavia, ainda não existem dados conclusivos acerca do papel deste hormônio na inflamação causada pelo evento isquêmico intestinal. Considerando que:

1. O estradiol participa por algum mecanismo da atividade funcional de órgãos e sistemas após o desencadeamento do trauma intestinal.

2. Receptores de estradiol estão presentes em células do sistema imune (PIERDOMINICl et al., 2010),

3. O sistema linfático atua como transportador de mediadores inflamatórios produzidos no intestino (ADAMS et al., 2001; DEITCH et al., 1994),

4. Dependendo da fase da resposta inflamatória, o estradiol pode exercer efeito protetor ou deletério,

5. Que a qualidade dos efeitos do estradiol depende do gênero,

a proposta que ora apresentamos visa a investigar a magnitude das repercussões intestinais induzidas pela IR intestinal com ênfase no papel do estradiol em fêmeas com ou sem ovários. Paralelamente, a importância da drenagem linfática também será investigada neste modelo. 


\section{OBJETIVOS}

O objetivo deste estudo foi avaliar as alterações da porção inicial do intestino delgado e as repercussões sistêmicas geradas pela IR intestinal em ratas e os efeitos do tratamento com estradiol.

Objetivos específicos:

$\rightarrow$ Comparar as alterações funcionais e estruturais do intestino após a IR intestinal;

$\rightarrow$ Investigar o efeito de tratamento dos animais com estradiol em diferentes fases da IR intestinal e comparar a expressão gênica dos receptores de estradiol no mesentério desses animais;

$\rightarrow$ Investigar a relevância da drenagem linfática para a integridade da microcirculação mesentérica, bem como sua composição;

$\rightarrow$ Avaliar o papel do estradiol sobre a mobilização celular entre os compartimentos medular, sistêmico e intestinal. 


\section{MATERIAIS E MÉTODOS}

\subsection{Preparação dos animais}

\subsubsection{Animais}

Foram utilizadas ratas Wistar adultas (60 dias), com peso entre 160 e $180 \mathrm{~g}$, provenientes do Biotério Central do Instituto de Ciências Biomédicas da Universidade de São Paulo. Os animais foram mantidos em condições de temperatura e umidade controladas em ciclo claro/escuro de $12 \mathrm{~h}$ no Biotério do Departamento de Farmacologia - Unidade I. As ratas tiveram livre acesso à ração e água. Os estudos em questão foram previamente aprovados pela Comissão de Ética no Uso de Animais do ICB/USP (111/2013).

\subsubsection{Grupos experimentais}

Os animais foram subdivididos em 6 grupos com as seguintes características:

Controle: fêmeas não manipuladas usadas para expressar os valores basais;

Sham: fêmeas OVx falsamente submetidas à IR intestinal;

$\underline{\text { IR: }}$ : fêmeas submetidas à IR intestinal;

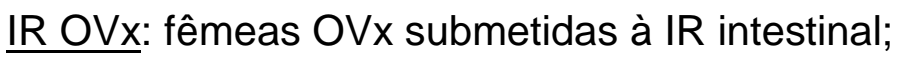

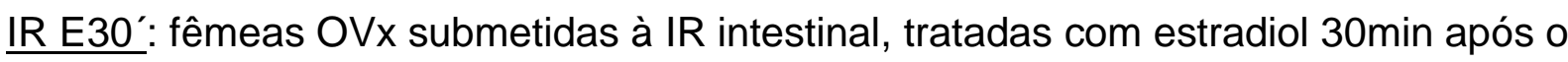
início da isquemia;

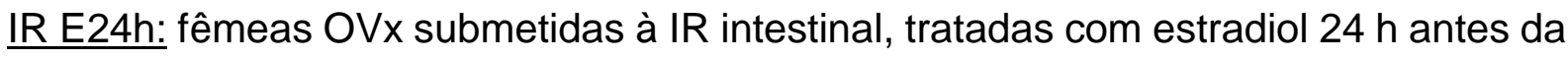
IR.

Já numa segunda parte do estudo, onde avaliamos a importância do sistema linfático e dos HSF na vigência da IR intestinal, separamos os animais em 4 novos grupos:

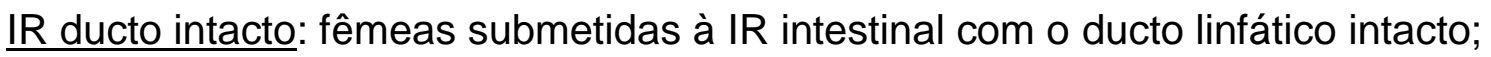
IR ducto ligado: fêmeas submetidas à IR intestinal com o ducto linfático obstruído; IR OVx ducto intacto: fêmeas OVx submetidas à IR intestinal com o ducto linfático intacto;

IR OVx ducto ligado: fêmeas OVx submetidas à IR intestinal com o ducto linfático obstruído. 


\subsubsection{Delineamento experimental}

Após a retirada junto ao biotério central, os animais foram matidos por uma semana para ambientação no biotério do Departamento de Farmacologia. Os animais foram submetidos aos seguintes delineamentos experimentais:

Figura 2 - Delineamento experimental de estudo.

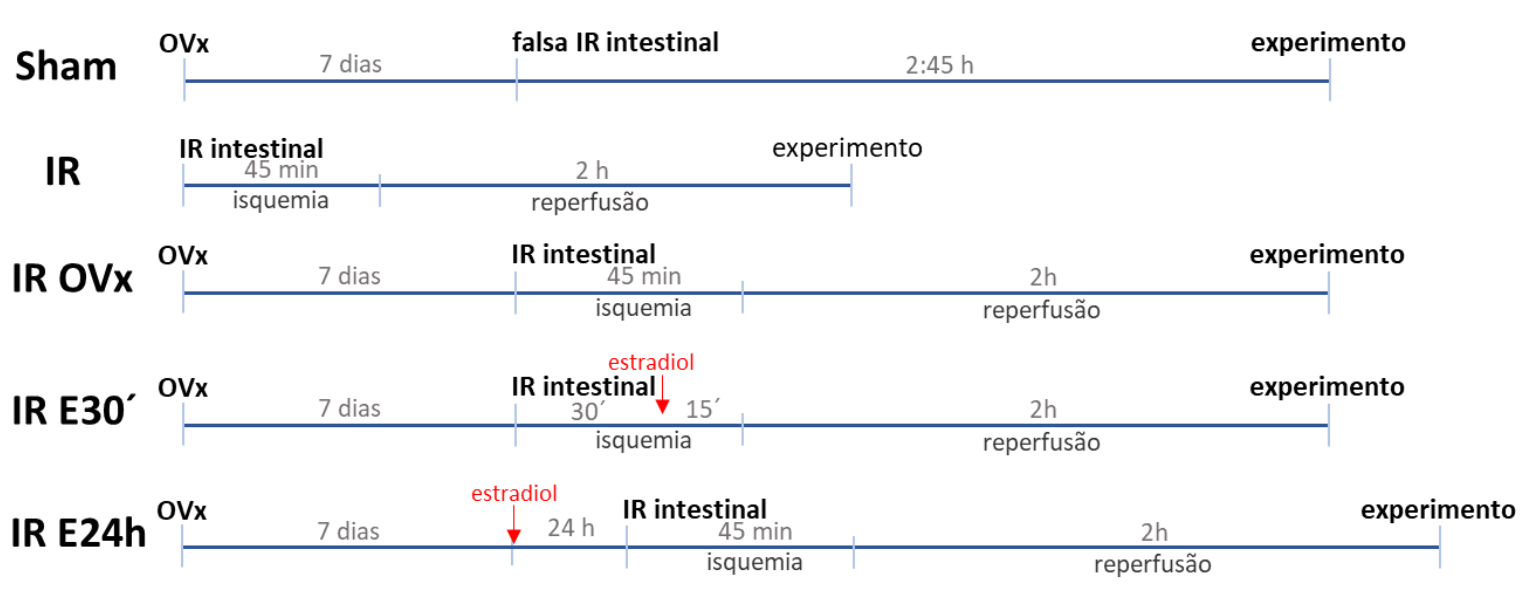

\subsection{Controle hormonal}

\subsubsection{Ovariectomia (OVx)}

As ratas foram medicadas previamente com tramadol $(5 \mathrm{mg} / \mathrm{kg}$, i.p. $-1 \mathrm{~h}$ antes da cirurgia). A seguir, foram anestesiadas com isoflurano ( $2 \% \mathrm{em} \mathrm{O}_{2}$ ), a seguir os ovários foram removidos utilizando o método descrito em Ligeiro-de-Oliveira et al. (2004). Após a cirurgia os animais receberam pentabiótico (540 mg/kg, i.m.). Durante três dias após a cirurgia os animais receberam paracetamol ad libitum $(0,53 \mathrm{mg} / \mathrm{ml}$ na água de beber). Decorridos 7 dias da cirurgia os animais foram submetidos à IR intestinal.

Figura 3 - Aparelho reprodutor de ratas com o processo cirúrgico para remoção dos ovários (lado esquerdo). 


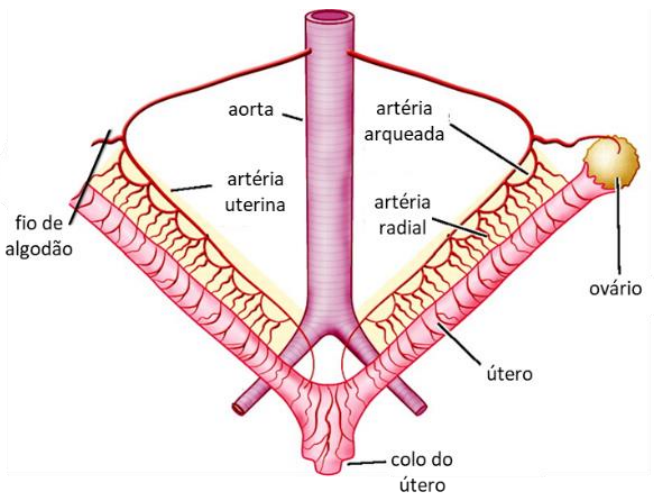

Imagem adaptada de: <http://newsmasters.info/anatom\%EDa-interna-de-una-rata>. Acesso em: 20 de Agosto de 2017, 18:35.

\subsubsection{Validação da ovariectomia}

O sucesso da ovariectomia foi avaliado pela análise do padrão morfológico das células presentes no lavado vaginal (LV). Para tanto, com o auxílio de um conta-gotas, solução salina tamponada com fosfatos (PBS) foi introduzida na vagina e o LV retirado. Amostras do LV foram colocadas sobre lâmina de vidro e a seguir diluídas em $5 \mu \mathrm{l}$ de corante azul de metileno ( $5 \%$ ) para serem observadas por microscopia óptica de luz (figura 4). Somente fêmeas ovariectomizadas em diestro pós ovariectomia foram incluídas nos experimentos dos grupos OVx tratados ou não.

Figura 4 - Lavado vaginal após OVx apresentando a fase diestro do ciclo estral, o qual observamos alta concentração de leucócitos.

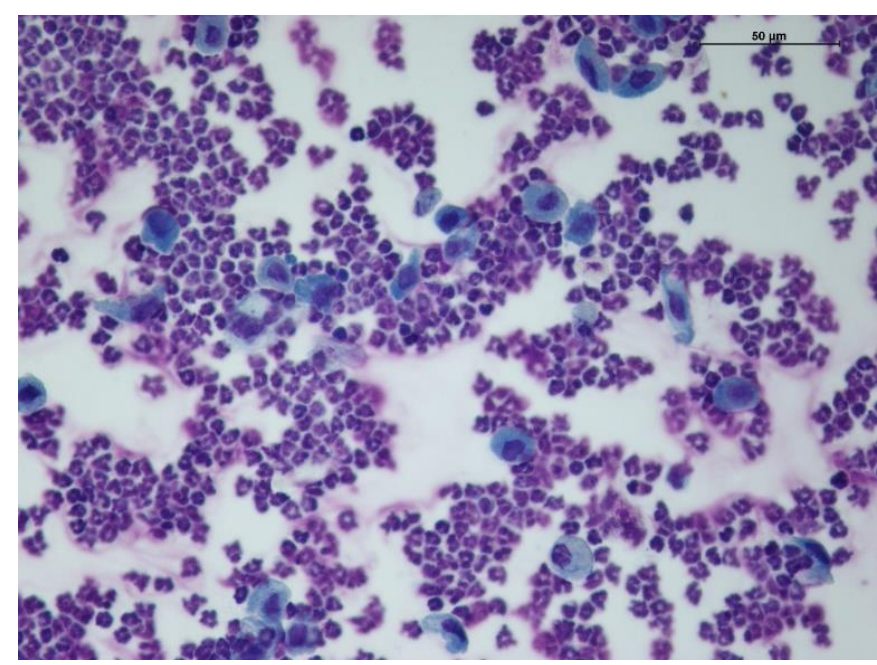




\subsubsection{Tratamentos farmacológicos}

Grupos de ratas foram tratados 30 min após o início da isquemia via intravenosa com 17ß-estradiol hidrossolúvel (Sigma-Aldrich, Missouri, EUA) ou $24 \mathrm{~h}$ antes da indução da isquemia intestinal via intramuscular com 17ß-estradiol lipossolúvel (Sigma-Aldrich, Missouri, EUA) diluído em óleo de girassol (Liza, Brasil), ambos na concentração de $280 \mu \mathrm{g} / \mathrm{kg}$. A concentração utilizada foi baseada em estudos prévios (LIGEIRO DE OLIVEIRA et al., 2004). Além disso, os animais submetidos a IR intestinal e não tratados com estradiol receberam o veículo do estradiol hidrossolúvel (ciclodextrina - Sigma-Aldrich, Missouri, EUA), usado no tratamento de 30 min após a isquemia $(4,9 \mathrm{mg} / \mathrm{kg}$, i.v. $)$.

\subsubsection{Determinação dos níveis séricos de estradiol}

Após os procedimentos cirúrgicos $(\mathrm{OVx})$ e a indução da IR intestinal, as dosagens hormonais foram realizadas. Para tanto, os animais foram anestesiados com cetamina/xilazina (100 e $20 \mathrm{mg} / \mathrm{kg}$, i.p.), a cavidade peritonial exposta e, o sangue total foi coletado da aorta abdominal e as amostras foram mantidas em geladeira (temperatura de 4 a $8{ }^{\circ} \mathrm{C}$ ) por $1 \mathrm{~h}$ para obtenção de soro para quantificação de estradiol. As concentrações circulantes dos hormônios foram determinadas utilizando kits de ELISA seguindo as instruções do fabricante (Cayman Chemical Company, Michigan, EUA).

\subsection{Modelos experimentais}

\subsubsection{Indução de IR intestinal}

As ratas foram anestesiadas com cetamina/xilazina ( $100 \mathrm{mg} / \mathrm{kg}$ e $20 \mathrm{mg} / \mathrm{kg}$, i.p.) e tramadol ( $5 \mathrm{mg} / \mathrm{kg}$, i.p.) para a analgesia, antes da cirurgia. Após laparotomia mediana e evisceração, a artéria mesentérica superior (AMS) foi localizada e a isquemia intestinal realizada (45 min) com clamp cirúrgico metálico de acordo com Cavriani et al., (2004). Durante o período de manutenção da isquemia, o abdômen dos animais foi coberto com filme estirável de PVC $(15 \mathrm{~cm} \times 10 \mathrm{~cm})$ para minimizar perdas de líquido e calor. Ao fim da isquemia, o clamp foi retirado e a incisão mediana fechada com sutura contínua, em dois planos, com fio de algodão polifilamentar de $0,5 \mathrm{~mm}$ de espessura. Após $2 \mathrm{~h}$ de reperfusão intestinal os animais foram submetidos à eutanásia, sob anestesia profunda, por exsanguinação da aorta abdominal. Como 
controle foram utilizados animais submetidos à manipulação cirúrgica, mas sem a oclusão da AMS, portanto, falsamente operados (Sham). Valores obtidos em animais não manipulados foram utilizados como valores basais.

\subsubsection{Obstrução do ducto linfático}

Os animais foram anestesiados com cetamina (100 mg/kg - i.p.) e xilazina (20 $\mathrm{mg} / \mathrm{kg}$ - i.p.) e submetidos à laparotomia na região subdiafragmática esquerda. As vísceras abdominais foram afastadas para a localização do ducto linfático torácico e sua obstrução foi realizada por ligadura com fio de algodão polifilamentar de 0,5 mm de espessura. Após a obstrução do ducto os animais foram submetidos a IR intestinal.

\subsubsection{Canulação do ducto torácico e obtenção da linfa}

Os animais foram anestesiados com cetamina (100 mg/kg - i.p.) e xilazina (20 $\mathrm{mg} / \mathrm{kg}$ - i.p.) e submetidos à laparotomia na região subdiafragmática esquerda. As vísceras abdominais foram afastadas para a localização do ducto linfático torácico, onde foi feita pequena incisão e canulação com tubo sylastic $(0,06 \mathrm{~cm}$ de diâmetro e $0,1 \mathrm{~cm}$ de diâmetro externo), previamente imerso em solução de heparina (500 Ul/ml). A seguir, a cânula foi amarrada com fio de algodão no ponto de inserção no ducto e sobre a massa muscular da parede abdominal posterior e a incisão fechada com sutura contínua com fio de nylon monofilamentar. Após a canulação do ducto linfático e após $1 \mathrm{~h}$ de reperfusão foi administrado $50 \mathrm{UI}$ de heparina $(0,1 \mathrm{ml}$ de PBS + solução de heparina $500 \mathrm{Ul} / \mathrm{ml}$ ) por via subcutânea. Os animais foram mantidos anestesiados em caixas de Bollman. As amostras da linfa foram coletadas em frascos contendo 100 $\mu l$ de PBS heparinizado: durante 20 min antes da isquemia (LC), durante a isquemia (45 min - LD) e durante a reperfusão (2 h - LR). As amostras de linfa foram centrifugadas (500 x $\mathrm{g}$ por $10 \mathrm{~min}$ ), as células foram separadas e o sobrenadante mantido a $-80^{\circ} \mathrm{C}$ para estudos subsequentes.

Figura 5 - Delineamento da coleta de linfa.

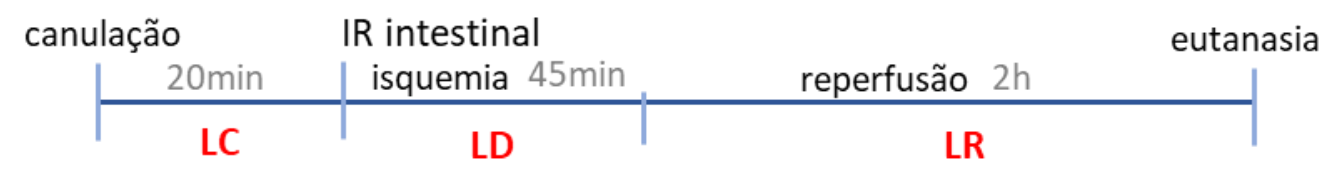




\subsection{Avaliação da inflamação local}

\subsubsection{Estudo da permeabilidade vascular intestinal}

A avaliação da permeabilidade vascular foi feita por meio da técnica de determinação da concentração do corante azul de Evans (AE) extravasado no intestino (CAVRIANI et al., 2004). O corante foi injetado por via intravenosa $20 \mathrm{~min}$ antes do fim das $2 \mathrm{~h}$ de reperfusão intestinal $(25 \mathrm{mg} / \mathrm{kg})$. Fragmentos da parte inicial do intestinal delgado foram removidos, limpos e pesados. Um deles foi colocado em formamida ( $4 \mathrm{ml} / \mathrm{g}$ de peso tecidual, a temperatura ambiente por $24 \mathrm{~h}$ ), enquanto o outro foi mantido em estufa de secagem $\left(56^{\circ} \mathrm{C}\right)$ por $24 \mathrm{~h}$, para obtenção do peso seco.

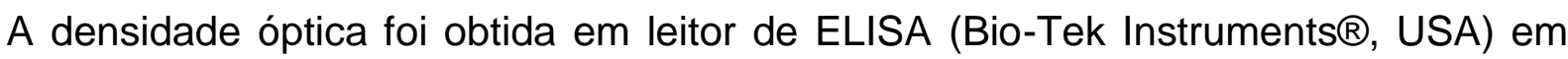
comprimento de onda $620 \mathrm{~nm}$ e os valores de $A E$ foram expressos em $\mu \mathrm{g}$ de $\mathrm{AE} / \mathrm{g}$. relação peso úmido/seco.

\subsubsection{Estudo da permeabilidade da mucosa intestinal}

Grupos de ratas receberam no início da reperfusão $50 \mathrm{mg} / \mathrm{kg}$ de dextran-FITC (4 kD, Sigma-Aldrich ${ }^{\circledR}$, EUA) diluídos em PBS, que foram injetados com seringa de tuberculina e agulha $0,38 \times 13 \mathrm{~mm}$ cuidadosamente no lúmen do duodeno exposto. Ao final do período de reperfusão intestinal, amostras de soro foram protegidas da luz obtidas e armazenadas em freezer $\left(-80^{\circ} \mathrm{C}\right)$ até a leitura por espectrofotometria de fluorescência $(495 \mathrm{~nm})$. A concentração de dextran-FITC nas amostras foi determinada com base em uma curva padrão, de $2000-0,24 \mathrm{ng} / \mathrm{mL}$ numa diluição 1:2. Esta técnica se baseia na quantificação de dextran-FITC que extravasa do lúmen do intestino para o sangue.

\subsubsection{Estudo do recrutamento/ativação de neutrófilos no intestino}

A atividade da enzima MPO foi baseada na metodologia descrita por Goldblum et al. (1985). Fragmentos da parte inicial do intestinal delgado foram removidos, pesados e congelados. Sendo depois homogeneizados em $3 \mathrm{ml} / \mathrm{g}$ de tampão fosfato pH 6,0 contendo $0,5 \%$ de brometo de hexadecil-tri-metil-amônio (HTAB) e 5 mM de ácido etilenodiamino tetra-acético (EDTA). Os homogenatos de intestino foram então centrifugados a $12000 \mathrm{rpm}$ durante $15 \mathrm{~min}$ a $4{ }^{\circ} \mathrm{C}$, e o sobrenadante obtido utilizado para determinar a atividade de MPO. O ensaio da atividade de MPO foi conduzido adicionando as placas de 96 poços $10 \mu \mathrm{l}$ da amostra. Às amostras foram adicionadas 
$200 \mu \mathrm{l}$ de substrato, contendo tampão fosfato $(\mathrm{pH} 6)$, peróxido de hidrogênio $(0,1 \%)$ e orto-dianisidina (1,25\%). Decorridos $5 \mathrm{~min}$, a reação foi paralisada pela adição de $50 \mu \mathrm{l}$ de azida sódica (1\%). A leitura da absorbância foi feita em leitor de ELISA (BioTek Instruments ${ }^{\circledR}$, EUA) em comprimento de onda de $450 \mathrm{~nm}$ e os valores expressos em atividade de MPO.

\subsubsection{Análise histológica}

Amostras da porção inicial do jejuno foram coletadas e mantidas em formol 10 \% por 24 h em temperatura ambiente. Após fixação em formol as amostras foram removidas e então foram acondicionadas em álcool $70 \%$ até serem enviadas para confecção das lâminas no laboratório da Prof. Dra. Patricia Gama no Departamento de Biologia Celular e do Desenvolvimento (ICB - USP, São Paulo, Brasil) utilizando o método de HE. Após processamento das lâminas, 10 fotos foram obtidas de cada corte de intestino utilizando software NIS- Elements F 4.30 acoplado à câmera Nikon Eclipse E-600. As imagens foram analisadas por meio do programa Image J (versão $1.50 \mathrm{~B}, \mathrm{EUA})$ e quantificamos a altura das vilosidades $(\mu \mathrm{m})$ e a profundidade das criptas intestinais $(\mu \mathrm{m})$.

Figura 6 - Fotomicrografia da mucosa intestinal.

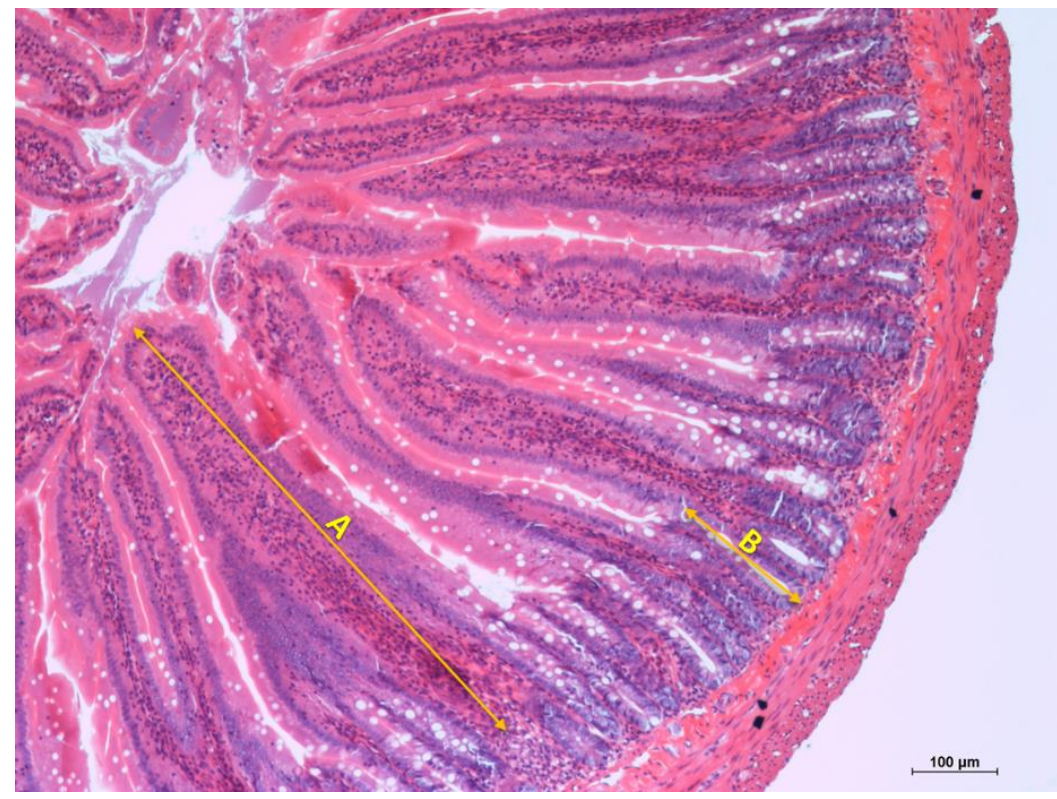

Em A: altura da vilosidade. Em B: profundidade da cripta. 


\subsubsection{Estudo do trânsito intestinal}

Os animais receberam imediatamente antes do procedimento anestésico, por gavagem, uma suspensão de carvão ativo a $20 \%(0,1 \mathrm{~mL} / 20 \mathrm{~g}$, Lafan Quimica Fina Ltda, SP). Decorrido o período de isquemia/reperfusão, os animais foram submetidos à eutanasia e foi retirada a porção do piloro até o início do ceco (RUWART, 1980). A distância percorrida pelo carvão ativo foi medida do piloro à ultima porção do intestino, que contivesse pelo menos $1 \mathrm{~cm}$ contínuo de carvão. A distância percorrida foi expressa em porcentagem do comprimento total do intestino delgado.

\subsubsection{Coleta e análise do fluido intestinal obtido durante a IR intestinal:}

Grupos de animais submetidos a IR intestinal tiveram seu intestino delgado e grosso envolvido e acondicionado em embalagem plástica $(9 \mathrm{~cm} \times 15 \mathrm{~cm})$ durante todo o período de isquemia e reperfusão (2:45 h) (NARITA et al., 2004). Ao final da IR intestinal as embalagens foram removidas, o volume do fluido intestinal e seu conteúdo leucocitário foi quantificado. Para isso $20 \mu \mathrm{l}$ do líquido intestinal foram homogeneizados em diluente para determinação do número total e diferencial de leucócitos. As amostras foram analisadas em analisador hematológico (BC-2800vet, Mindray, China).

\subsubsection{Determinação dos níveis de interleucina-10 (IL-10) e CINC-1 no fluido intestinal} obtido durante a IR intestinal

Amostras de fluido intestinal foram utilizadas para determinação dos níveis de IL-10 e CINC-1 por meio de kits comerciais (Duo Set, R \& D System®). Os ensaios foram conduzidos seguindo as especificações do fabricante e a densidade óptica obtida em leitor de ELISA (Bio-Tek Instruments ${ }^{\circledR}$ ) em 450 nm.

\subsubsection{Perfil genético inflamatório e da sinalização receptores do estradiol do} mesentério por PCR array em tempo real

Primeiramente fragmentos de mesentério, conservados em RNA "later" e congelados em freezer $-80^{\circ} \mathrm{C}$, foram utilizados para a extração do RNA segundo kit RNAeasy Plus Micro (QIAGEN, EUA). As amostras a serem utilizadas foram selecionadas por meio da placa de qualidade (Placa QC, QIAGEN, EUA). Por fim, a expressão gênica foi quantificada com as placas PARN-011Z $\mathrm{RT}^{2}$ Profiler $^{\mathrm{TM}}$ (perfil 
inflamatório) e PARN-005Z $\mathrm{RT}^{2}$ Profiler ${ }^{\mathrm{TM}}$ (perfil da sinalização de receptores de estradiol) (QIAGEN, EUA) utilizando o aparelho Step One plus (Applied Biosystem, EUA) nas condições de ciclagem: 40 ciclos de 15 segundos à $95^{\circ} \mathrm{C}$ e 1 minuto à $60{ }^{\circ} \mathrm{C}$.

\subsection{Avaliação da inflamação sistêmica}

3.5.1 Determinação número total e diferencial de leucócitos e do número de plaquetas circulantes

Amostras de sangue $(20 \mu \mathrm{l})$ foram coletadas da cauda dos animais antes da indução da isquemia, após o término do período de reperfusão. Foi utilizada pipeta automática para coletar a amostra, que foi homogeneizada em diluente e submetida à contagem automática total e diferencial em analisador hematológico (BC-2800vet, Mindray, China).

\subsubsection{Determinação do número total de células na medula óssea}

O fêmur esquerdo foi cirurgicamente removido, ambas as extremidades foram abertas e o canal medular foi perfundido a partir da extremidade distal, pela introdução de uma agulha acoplada à uma seringa contendo $10 \mathrm{ml}$ de PBS. A suspensão medular foi homogeneizada como o auxílio de uma pipeta e a seguir as células totais foram contadas em câmara de Neubauer por microscopia óptica. Para tanto, $90 \mu \mathrm{l}$ da amostra foi acrescida de $10 \mu \mathrm{l}$ de cristal violeta, seguido de uma segunda diluição de 1:10 em PBS, para que as células sejam expressas $\times 10^{6} / \mathrm{ml}$.

\subsubsection{Ensaio de quimiotaxia in vitro com neutrófilos circulantes}

O volume total de sangue $(5 \mathrm{~mL})$ foi coletado de animais anestesiados pela artéria aorta abdominal com auxílio de seringa $(5 \mathrm{~mL})$ e agulha $(0,8 \times 25 \mathrm{~mm})$ contendo citrato (Citrate concentrated solution, Sigma-Aldrich®, EUA). Os neutrófilos foram separados por centrifugação em gradiente de Ficoll:Hipaque (Histopaque, SigmaAldrich®, EUA) com metodologia baseada em Newman et al. (1982). Para tanto, em um tubo plástico $(15 \mathrm{ml}$ ) foram colocados $5 \mathrm{ml}$ de Histopaque e $5 \mathrm{ml}$ de sangue total misturado em proporção 1:1 com PBS. Em seguida o tubo foi centrifugado a 1300 rpm por 50 min, à temperatura ambiente. O plasma, as células mononucleares e o Histopaque foram descartados. No tubo contendo neutrófilos e hemácias foram 
adicionados $2 \mathrm{ml}$ de dextran (6\%), homogeneizados por inversão e incubados por 1 h a $37^{\circ} \mathrm{C}$ com o tubo inclinado $\left(45^{\circ}\right)$. O sobrenadante, contendo os neutrófilos, foi recolhido e centrifugado a $1200 \mathrm{rpm}$ por $10 \mathrm{~min}$. Ao "pellet", contendo neutrófilos e hemácias, foi adicionado cloreto de amônia, para lise destas últimas, seguido de nova centrifugação. Os neutrófilos foram então ressuspendidos em meio de cultura (RPMI, Sigma-Aldrich $\left.{ }^{\circledR}, E \cup A\right)$, contados e preparados para ensaio de quimiotaxia in vitro, acertando o volume para $2 \times 10^{6}$ células $/ \mathrm{mL}$. O ensaio de quimiotaxia se baseia na migração de células através de um filtro poroso. Para o ensaio foi utilizada uma placa de quimiotaxia da ChemoTx® System (Neuro Probe, Inc., EUA), contendo uma placa de 96 poços e uma placa com filtro de câmara (com poros de $3 \mu \mathrm{m}$ ), dessa forma a metodologia foi realizado de acordo com Riffo-Vasquez et al. (2014). Após bloqueio com meio de cultura contendo $1 \%$ de BSA adicionado $30 \mu \mathrm{l}$ de RPMI em cada poço da microplaca. Na sequência, o filtro foi posicionado acima da placa e foram adicionados $20 \mu \mathrm{l}$ da solução contendo $4 \times 10^{4}$ neutrófilos sobre o sitio hidrofílico do filtro. A placa com filtro foi colocada na estufa $\left(37^{\circ} \mathrm{C}\right)$ e incubada por $90 \mathrm{~min}$. O filtro foi então removido e $20 \mu \mathrm{l}$ da suspensão de neutrófilos em RPMl contida em cada poço da microplaca foram diluídos com cristal violeta (1:1) e a contagem de células efetuada em câmara de Neubauer com microscópio óptico comum.

\subsubsection{Determinação dos níveis de mediadores no soro}

A quantificação dos níveis das citocinas: estimulador de colônias de granulócitos

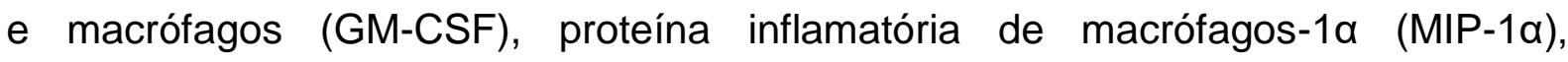
interleucina-1 $\beta$ (IL-1 $\beta$ ), interleucina-6 (IL-6), interleucina-10 (IL-10), interleucina-12p70 (IL-12p70), interferon-y (IFN-ץ), interleucina-17 (IL-17), proteína quimiotática de monócitos-1 (MCP-1), proteína induzida pelo IFN- $\mathrm{Y}-10$ (IP-10), oncogene relacionado ao crescimento/quimiotático de queratinócitos (CINC-1), fator de crescimento endotelial vascular (VEGF) e fator de necrose tumoral- $\alpha$ (TNF- $\alpha$ ) foi realizada com a utilização de kit comercial Milliplex® (Merck Millipore, EUA). As amostram foram coletadas e o ensaio foi conduzido seguindo as especificações do fabricante e a leitura foi realizada com o equipamento Luminex 200 - Software xPonent/Analyst versão 4.2. 


\subsection{Participação do sistema linfático}

\subsubsection{Determinação dos níveis de mediadores na linfa}

Alíquotas de $100 \mu \mathrm{l}$ de linfa foram adicionadas a poços em microplacas plásticas (96 poços). A determinação de IL-1ß, IL-6 e IL-10 foi realizada pela utilização do kit comercial Duo Set (R\&D System $\AA$, EUA). O ensaio foi conduzido seguindo as especificações do fabricante e a densidade óptica obtida em leitor de ELISA (Biotek®) Instruments, EUA).

\subsubsection{Determinação do volume e número total de leucócitos presentes na linfa}

Após coleta da linfa, estimamos a quantidade de linfa coletada e calculamos volume de linfa $(\mu \mathrm{l})$ por minuto. Antes da centrifugação, amostras de linfa (20 $\mu \mathrm{l})$ foram coletadas com pipeta automática e homogeneizada em diluente para serem submetidas à contagem automática em analisador hematológico (BC-2800vet, Mindray, China).

\subsubsection{Identificação das células presentes na linfa por citometria de fluxo}

Após coleta da linfa, as células foram separadas por centrifugação (4000 g 5 min) e foram adicionados $500 \mu \mathrm{l}$ de Paraformoldeído (Sigma, EUA) $1 \%$ em PBS (Sigma, EUA) onde permaneceram por 30 minutos. Foram adicionados $1 \mathrm{~mL}$ de PBS em todas as amostras e separadas em 4 tubos diferentes e novamente centrifugadas. O sobrenadante foi removido e adicionado $25 \mu \mathrm{l}$ dos respectivos coquetéis: 1. AntiRat MHC Class II - PE (eBioscience, EUA) e Anti-Rat CD11 b/c - eFluor660 (eBioscience, EUA); 2. Anti-Rat MHC Class II - PE (eBioscience, EUA) e Mouse AntiRat CD5 - Alexa Fluor (AbD Serotec, Reino Unido); 3. Anti-Rat MHC Class II - PE (eBioscience, EUA), Anti Ly6G/GR1 Neutrophil - FITC (GmbH, Alemanha) e Anti-Ly6C - APC (Antibodies, EUA); 4. Anti-Rat CD8a - APC (eBioscience, EUA) e Anti-Rat CD4 - FITC (eBioscience, EUA). As amostras foram incubadas em geladeira por 30 min e, então centrifugadas ( $4000 \mathrm{~g} 5 \mathrm{~min}$ ). O sobrenadante foi removido e adicionado $100 \mu \mathrm{l}$ de PBS. As amostras foram lidas e analisadas por meio do citômetro BD AccuriTM (BD, EUA). 


\subsection{Análise estatística}

As análises estatísticas, determinadas de acordo com o desenho experimental, foram conduzidas utilizando GraphPad Prism 6.0. Os dados obtidos foram expressos como média $\pm E P M$ e o nível de significância adotado foi $p<0,05$. Empregou-se o teste ANOVA de duas vias seguido pelo teste Tukey para as análises de celularidade no sistema circulatório e também dos animais com ducto intacto $x$ ligado. Nas demais análises foram utilizadas o teste ANOVA de uma via seguido de teste de Tukey. 


\section{RESULTADOS}

\subsection{Validação do tratamento com estradiol}

\subsubsection{Determinação da concentração sérica de estradiol}

A figura 7 representa a concentração sérica de estradiol em ratas. Os dados mostram a concentração deste hormônio em ratas não manipuladas (basal), em ratas após 7 dias da remoção dos ovários (OVx) e em ratas OVx tratadas com estradiol 30 min após o início da isquemia (280 $\mu \mathrm{l} / \mathrm{kg}$, i.v.) ou $24 \mathrm{~h}$ antes da indução da isquemia (280 $\mu \mathrm{l} / \mathrm{kg}$, s.c.). Como pode ser observado, a concentração de estradiol circulante decai de forma significativa 7 dias após a ovariectomia (OVx), confirmando, desta forma, a eficácia do procedimento.

Os tratamentos dos animais OVx com estradiol foram também efetivos, aumentando a concentração sérica do hormônio em relação ao grupo OVx. É digno de nota que o tratamento 30 min após da indução da isquemia gerou níveis de estradiol suprafisiológicos e que podem ser considerados terapêuticos uma vez que a sua administração ocorre 30 após a isquemia. Já o tratamento de estradiol $24 \mathrm{~h}$ antes da indução da isquemia (preventivo) resultou em concentração semelhante ao apresentado por animais basais.

Figura 7 - Valores de estradiol no soro de ratas com os ovários intactos (basal) ou 7 dias após a ovariectomia (OVx) e após tratamento dos animais com estradiol $(280 \mu \mathrm{g} / \mathrm{kg}) 30 \mathrm{~min}$ após a isquemia ou $24 \mathrm{~h}$ antes da isquemia. O sangue foi coletado pela artéria aorta após a eutanásia dos animais e processado para obtenção do soro. Os valores foram obtidos através de kits de ELISA e representam a média \pm EPM entre 2 a 5 amostras. ${ }^{*} P<0,05$ em relação ao grupo basal; ${ }^{\Phi} P<0,05$ em relação ao grupo OVx.

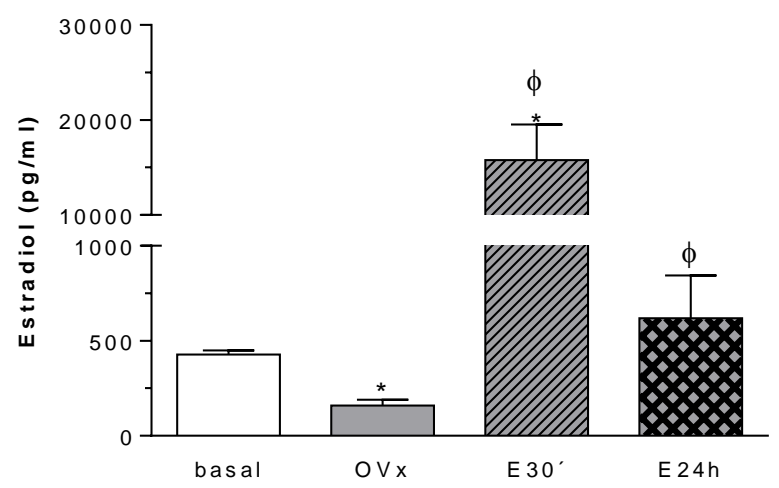

\subsection{Efeito do estradiol na inflamação local decorrente à IR intestinal}

Em um primeiro momento, avaliamos as consequências intestinais geradas após a IR intestinal em fêmeas com ovários intactos ou removidos e, também, o efeito 
do tratamento com estradiol nos animais OVx. Estes estudos permitiram avaliar 0 comprometimento da barreira e funcionalidade intestinal bem como, a geração de citocinas e a presença de células inflamatórias locais.

\subsubsection{Permeabilidade macromolecular intestinal}

A avaliação da permeabilidade macromolecular intestinal foi realizada por meio do extravasamento de dextran-FITC do lúmen do duodeno para a circulação dos animais submetidos à IR intestinal. Na figura 8 (Painel A) é possível notar que em fêmeas falsamente operadas (Sham) a permeabilidade da mucosa intestinal é baixa e que após a indução da IR intestinal tanto nos animais OVx como nos com ovários intactos, ocorre aumento significativo da concentração de dextran-FITC no soro.

O painel B representa o efeito dos tratamentos com estradiol sobre a permeabilidade da mucosa. Como pode ser observado apenas o tratamento dos animais com estradiol $24 \mathrm{~h}$ antes da indução da isquemia diminuiu o significativamente a concentração de dextran-FITC quantificada no soro dos animais.

Este estudo, permitiu avaliar o comprometimento da mucosa intestinal gerado pela IR intestinal e o efeito dos tratamentos com estradiol, que foram capazes de reduzir o extravasamento do conteúdo intestinal para o soro dos animais.

Figura 8 - Determinação da concentração de Dextran-FITC no soro. As ratas OVx ou não foram submetidas ou não (sham) à isquemia (45 min) e reperfusão intestinal (2 horas - IR intestinal). A administração de estradiol foi realizada com 30 min de isquemia ou $24 \mathrm{~h}$ antes da isquemia com a mesma dosagem $(280 \mu \mathrm{g} / \mathrm{kg})$. Os dados representam a média \pm EPM de 6 a 9 amostras. ${ }^{\star} P<0,05$ em relação ao grupo sham. ${ }^{\alpha} P<0,05$ em relação ao grupo IR $O V x$.
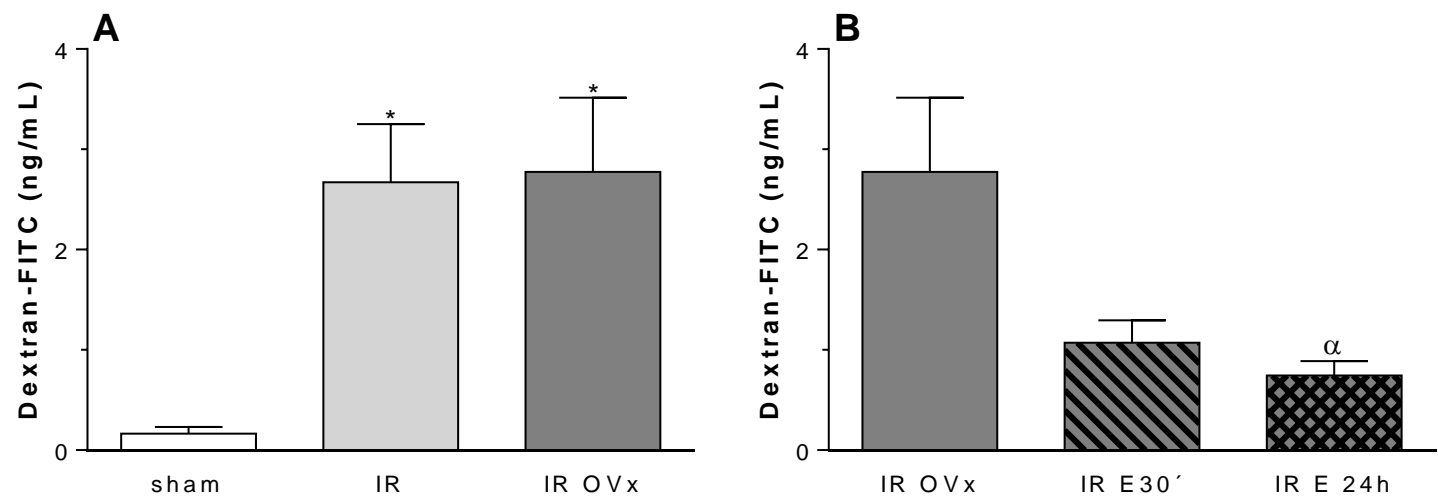

\subsubsection{Permeabilidade vascular intestinal}

Ao analisarmos a permeabilidade vascular podemos mensurar a quantidade de proteínas extravasadas da circulação sanguínea para o intestino, avaliando assim, a inflamação local gerada. 
Os dados representados na figura 9 (painel A) mostram que a indução da IR intestinal provocou alterações na permeabilidade vascular intestinal dos animais com ovários removidos em comparação ao grupo sham e ao grupo de animais com ovários intactos. O tratamento dos animais OVx com estradiol 30min após a indução da isquemia não alterou os valores de extravasamento do corante Azul de Evans no intestino em comparação ao grupo IR OVx (sem tratamento). Todavia o tratamento com estradiol $24 \mathrm{~h}$ antes da isquemia reduziu o extravasamento do corante de maneira significante (Figura 9, painel B).

Figura 9 - Efeito da OVx (painel A) e do tratamento com estradiol (painel B) sobre o extravasamento intestinal do corante azul de Evans. As ratas OVx ou não foram submetidas ou não (sham) à isquemia (45 $\mathrm{min}$ ) e reperfusão intestinal (2 horas - IR intestinal). Valores basais foram obtidos de ratas não manipuladas. A administração de estradiol foi realizada com 30 min de isquemia ou $24 \mathrm{~h}$ antes da isquemia com a mesma dosagem $(280 \mu \mathrm{g} / \mathrm{kg})$. O corante AE $(20 \mathrm{mg} / \mathrm{kg})$ foi injetado $20 \mathrm{~min}$ antes do término da reperfusão. Os dados representam a média \pm EPM de 7-29 animais. ${ }^{*} P<0,01 \mathrm{em}$ relação ao grupo sham; ${ }^{\phi} P<0,05$ em relação ao grupo IR; ${ }^{\alpha} P<0,01$ em relação ao grupo IR OVx.
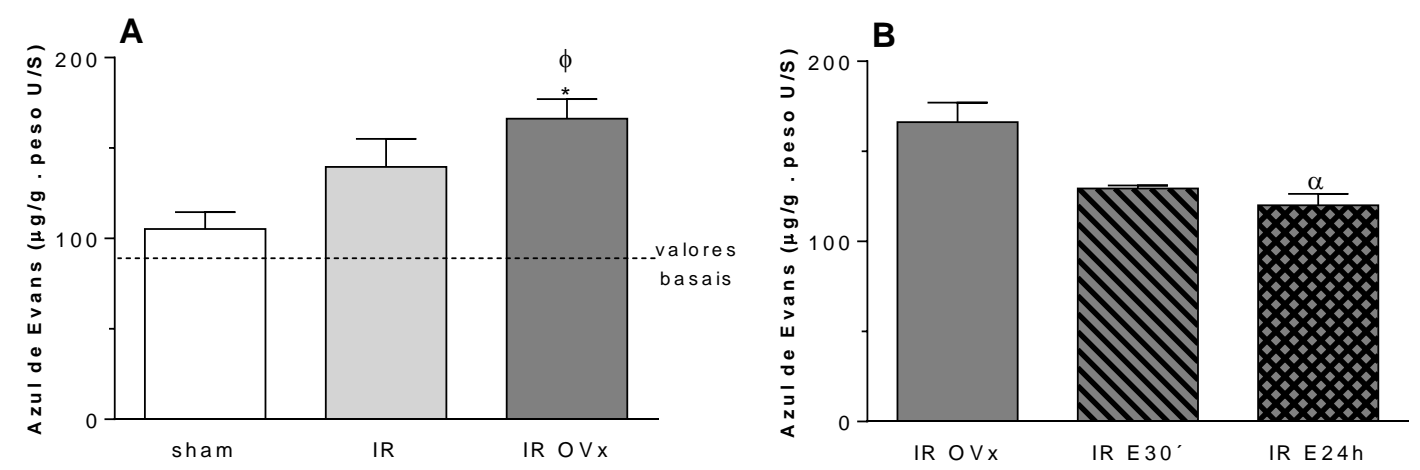

\subsubsection{Recrutamento/Ativação de neutrófilos}

$\mathrm{Na}$ medida em que a IR intestinal induz inflamação e o intestino pode ser considerado o motor da inflamação que irá disseminar sistemicamente a inflamação e assim interferir com outros órgãos, avaliamos a presença/ativação dos neutrófilos na porção inicial do intestino após a IR intestinal por meio da técnica de quantificação da atividade de MPO no intestino. Os dados gerados estão representados no painel A da figura 10 e mostram que a IR intestinal no grupo OVx aumentou a atividade da enzima MPO em relação ao grupo sham. Com relação aos tratamentos com estradiol podemos observar que ambos foram efetivos em reduzir os valores de MPO em comparação ao grupo IR OVx (Figura 10, painel B). 
Figura 10 - Efeito da OVx e do tratamento com estradiol sobre a atividade de MPO em homogenatos de intestino. As ratas OVx ou não foram submetidas ou não (Sham) à isquemia (45 min) e reperfusão intestinal (2 horas - IR intestinal). Valores basais foram obtidos de ratas não manipuladas. A administração de estradiol foi realizada com $30 \mathrm{~min}$ de isquemia ou $24 \mathrm{~h}$ antes da isquemia com a mesma dosagem $(280 \mu \mathrm{g} / \mathrm{kg})$. Os dados representam a média \pm EPM de 5 a 9 amostras. ${ }^{*} P<0,01 \mathrm{em}$ relação ao grupo sham; ' $P<0,01 \mathrm{IR}$ E30' em relação ao grupo IR OVx; ; ${ }^{a}<<0,05 \mathrm{IR}$ E24h em relação ao grupo IR OVx.
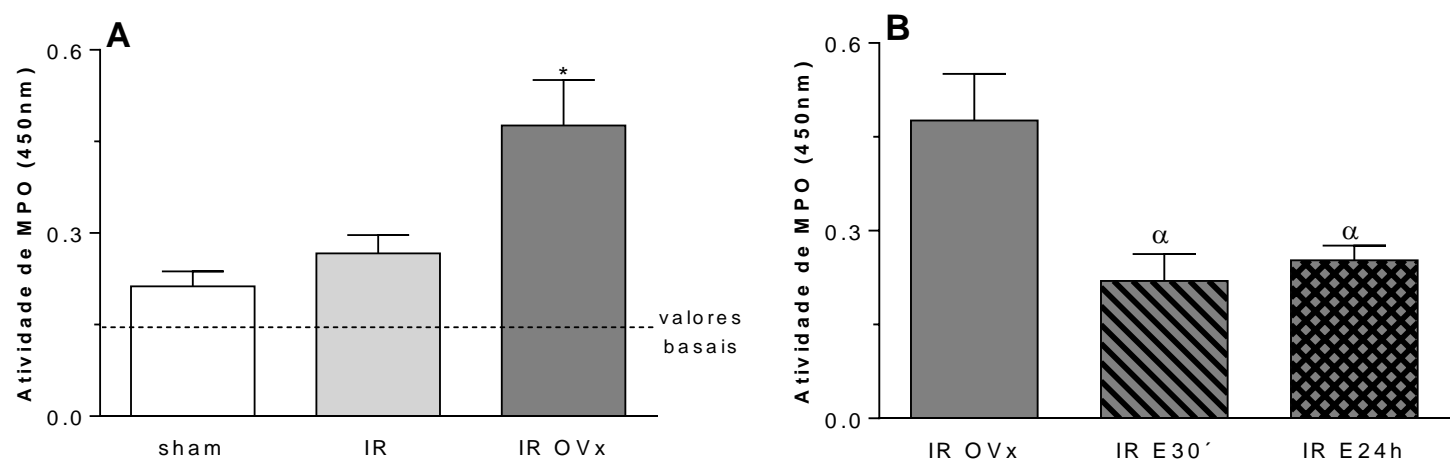

\subsubsection{Morfometria da mucosa intestinal}

Uma vez que identificamos alterações na celularidade e permeabilidade intestinal, avaliamos a integridade da mucosa intestinal após a IR intestinal mensurando o comprimento das vilosidades e a profundidade das criptas em amostras do segmento inicial do intestino dos animais.

Os dados obtidos estão representados na figura 11 e indicaram que fêmeas com ovários intactos após a IR intestinal possuem aumento da profundidade das criptas após a IR intestinal em comparação com o grupo Sham (painel A) e, somente o tratamento com estradiol $24 \mathrm{~h}$ antes da IR intestinal reduziu a profundidade das criptas (painel B).

Analisando a altura das vilosidades (painel C e D, figura 11) observamos redução no grupo IR OVx em relação ao grupo IR e, ao tratarmos os animais com estradiol houve aumento na altura das vilosidades no grupo IR E30'e redução no grupo IR E 24h ao compará-los com o grupo IR OVx. 
Figura 11 - Análise histológica do comprimento das vilosidades e da profundidade das criptas intestinais de fragmentos da porção inicial do intestino de fêmeas submetidas a IR intestinal. Valores basais foram obtidos de ratas não manipuladas. A administração de estradiol foi realizada com 30 min de isquemia ou $24 \mathrm{~h}$ antes da isquemia com a mesma dosagem $(280 \mu \mathrm{g} / \mathrm{kg})$. Os dados representam a média \pm EPM de 5 a 9 amostras. Painel $\mathrm{A}:{ }^{*} P=0,01$ em relação ao grupo sham. Painel $\mathrm{B}:{ }^{\alpha} P<0,0001$ em relação ao grupo IR OVx. Painel C: ${ }^{\Phi} P=0,04$ em relação ao grupo IR. Painel D: ${ }^{\alpha} P<0,0001 \mathrm{IR}$ E30' em relação ao grupo IR OVx; ${ }^{\alpha} P<0,0001$ IR E24h em relação ao grupo IR OVx.
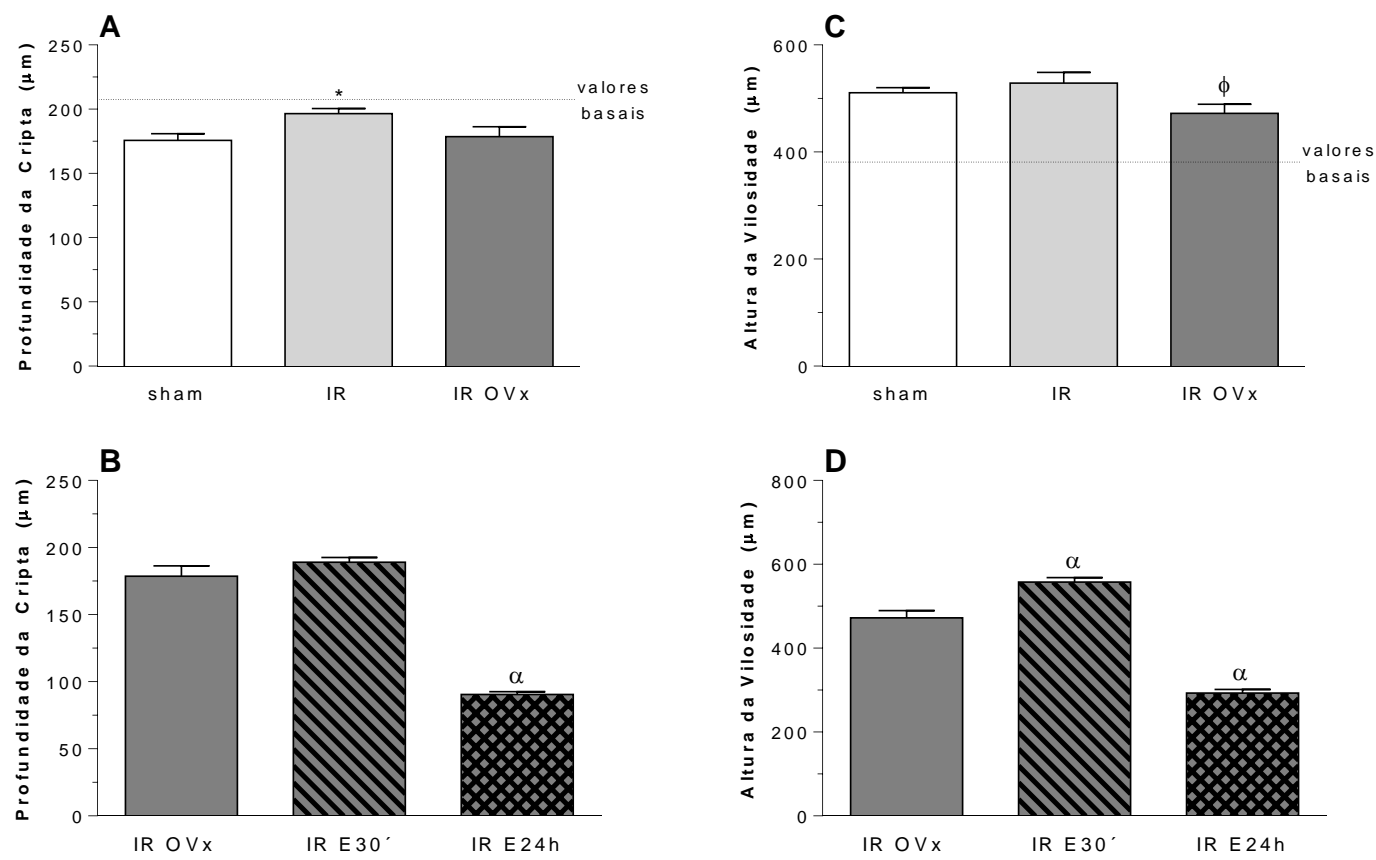

\subsubsection{Trânsito intestinal}

Uma vez que identificamos alterações morfológicas e inflamatórias no intestino dos animais submetidos à IR intestinal, procuramos avaliar sua funcionalidade realizando o teste de carvão ativado que permite mensurar o trânsito intestinal.

$\mathrm{Na}$ figura 12 observamos que a IR intestinal causou aumento do trânsito intestinal em animais não OVx assim como em animais OVx tratados com estradiol 24 $\mathrm{h}$ antes de serem submetidos a IR intestinal. Além disso, a remoção dos ovários e o tratamento dos animais OVx com estradiol 30 min após a indução da isquemia não modificaram o perfil do trânsito intestinal. 
Figura 12 - Porcentagem, em relação ao comprimento total do intestino delgado, de trânsito do carvão ativado em ratos submetidos à isquemia $(45 \mathrm{~min})$ e reperfusão intestinal (2 horas - IR intestinal). Os grupos consistiram de animais submetidos à IR intestinal com ou sem ovários, tratados com estradiol (30min depois ou $24 \mathrm{~h}$ antes da isquemia), falsamente operados (Sham) e animais não

manipulados (Basal). Os dados representam a média \pm EPM de 4-8 experimentos. ${ }^{*} P<0,05 \mathrm{em}$ relação ao grupo Sham; $\alpha P<0,05$ em relação ao grupo IR OVx.
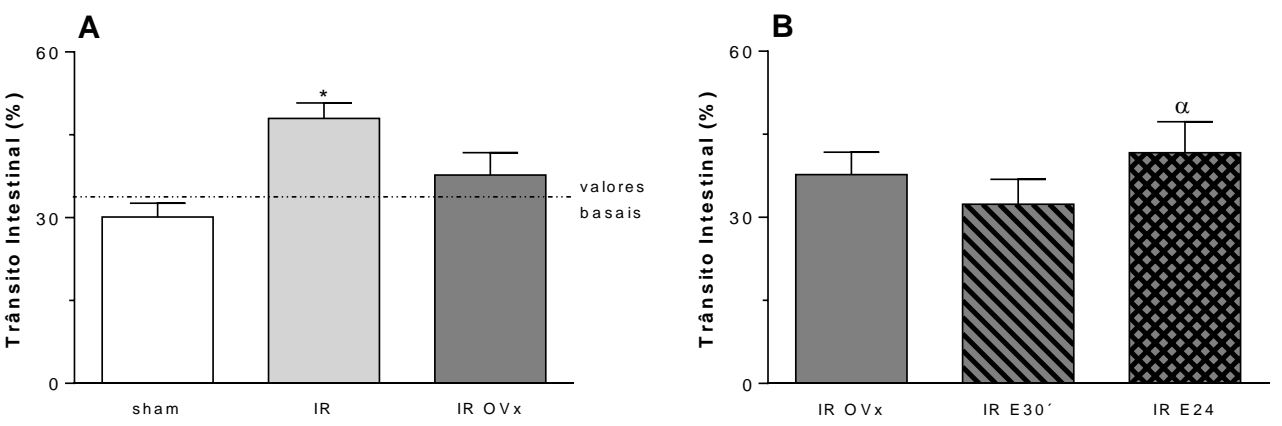

\subsubsection{Estudo do fluido intestinal gerado durante a IR intestinal}

Nesta fase do estudo, decidimos avaliar o fluido intestinal gerado durante a IR intestinal, o objetivo neste momento era avaliar o conteúdo presente neste fluido como sua celularidade e citocinas e assim, dar continuidade ao perfil inflamatório investigado durante o estudo.

Na primeira série de estudos do fluido intestinal coletado analisamos o volume de fluido intestinal recuperado representado na figura 13. Os nossos dados revelaram redução significativa do volume de fluido intestinal gerado nos animais submetidos a IR intestinal em comparação aos animais do grupo de animais sham. Vale lembrar que o tratamento com estradiol não interferiu com o volume coletado, sugerindo que a alteração causada pela IR intestinal à dinâmica dos fluidos no intestino não é mediada pelo estradiol.

Figura 13 - Volume de fluido intestinal recuperado da embalagem plástica das ratas após a IR intestinal. As ratas OVx ou não foram submetidas ou não (Sham) à isquemia (45 min) e reperfusão intestinal (2 horas - IR intestinal). A administração de estradiol foi realizada com $30 \mathrm{~min}$ de isquemia ou $24 \mathrm{~h}$ antes da isquemia com a mesma dosagem $(280 \mu \mathrm{g} / \mathrm{kg})$. Os dados representam a média \pm EPM de 7 a 12 amostras. ${ }^{*} P<0,05$ em relação ao grupo sham.
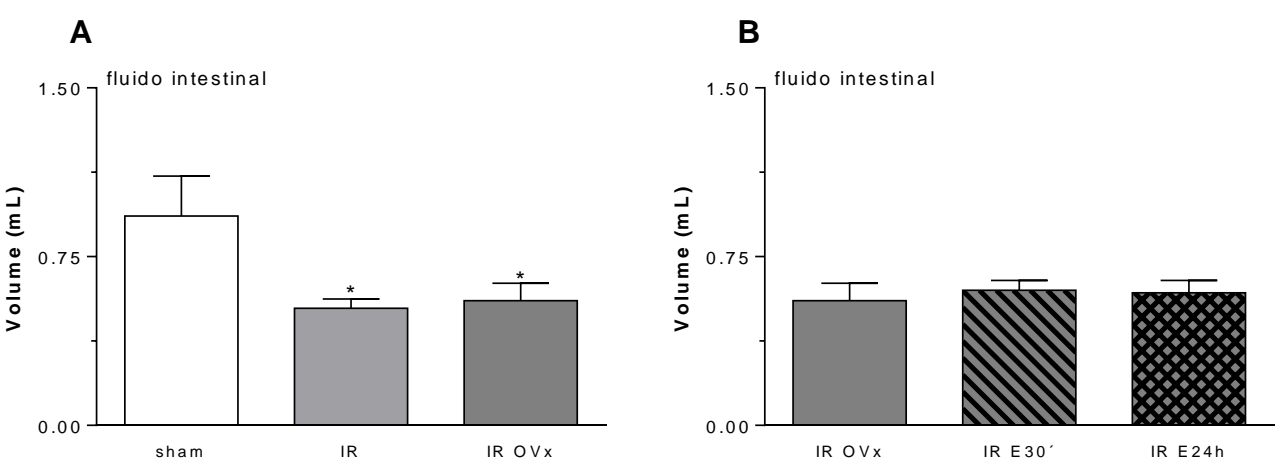
Considerando que o intestino de ratas sob IR intestinal teria recrutado células inflamatórias e que estas contribuírem com as alterações de homeostasia do compartimento, decidimos investigar o número de leucócitos presentes no fluido intestinal obtido desses animais. Os dados estão representados na figura 14. Como pode ser observado (painel A), o fluido intestinal dos animais dos grupos IR intestinal e IR OVx apresentaram redução do número de leucócitos em relação ao quantificado nas amostras do grupo de animais Sham. Por outro lado (painel B), o tratamento dos animais com estradiol não alterou o número de leucócitos no fluido.

Figura 14 - Número total de leucócitos presentes no fluido intestinal recuperado da embalagem plástica das ratas após a IR intestinal. As ratas OVx ou não foram submetidas ou não (sham) à isquemia (45 min) e reperfusão intestinal (2 horas - IR intestinal). A administração de estradiol foi realizada com $30 \mathrm{~min}$ de isquemia ou $24 \mathrm{~h}$ antes da isquemia com a mesma dosagem ( $280 \mu \mathrm{g} / \mathrm{kg})$. Os dados representam a média \pm EPM de 5 a 6 amostras. ${ }^{*} P<0,05$ em relação ao grupo sham; ${ }^{*} P<0,01$ em relação ao grupo sham.
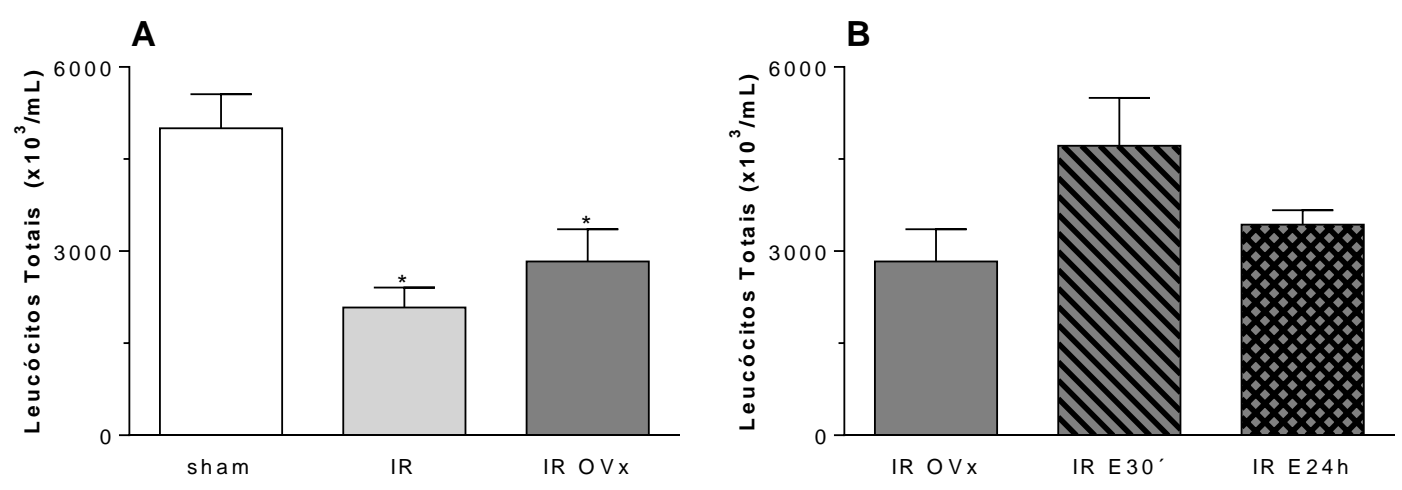

Uma vez determinado o número total de células no fluido intestinal quantificamos o número dos diferentes tipos de leucócitos. Os dados estão representados na figura 15 e mostram que não houve aumento significativo na quantidade de linfócitos (Painéis 1A e 1B) e de monócitos (Painéis 2A e 2B). Porém os granulócitos se mostraram em menor quantidade após a IR intestinal nos grupos com e sem ovários (Painel 3A). Com respeito aos efeitos de tratamentos, nossos estudos indicaram que os dois tratamentos não alteraram as quantidades celulares em relação ao grupo IR OVx (Painel 3B). 
Figura 15 - Quantificação dos linfócitos (painel 1), monócitos (painel 2) e granulócitos (painel 3) presentes no fluido intestinal. As ratas OVx ou não foram submetidas ou não (sham) à isquemia (45 min) e reperfusão intestinal (2 horas - IR intestinal). A administração de estradiol foi realizada com 30 min de isquemia ou $24 \mathrm{~h}$ antes da isquemia com a mesma dosagem $(280 \mu \mathrm{g} / \mathrm{kg})$. Os dados representam a média \pm EPM de 5 a 6 amostras. ${ }^{* *} P<0,01$ em relação ao grupo sham.
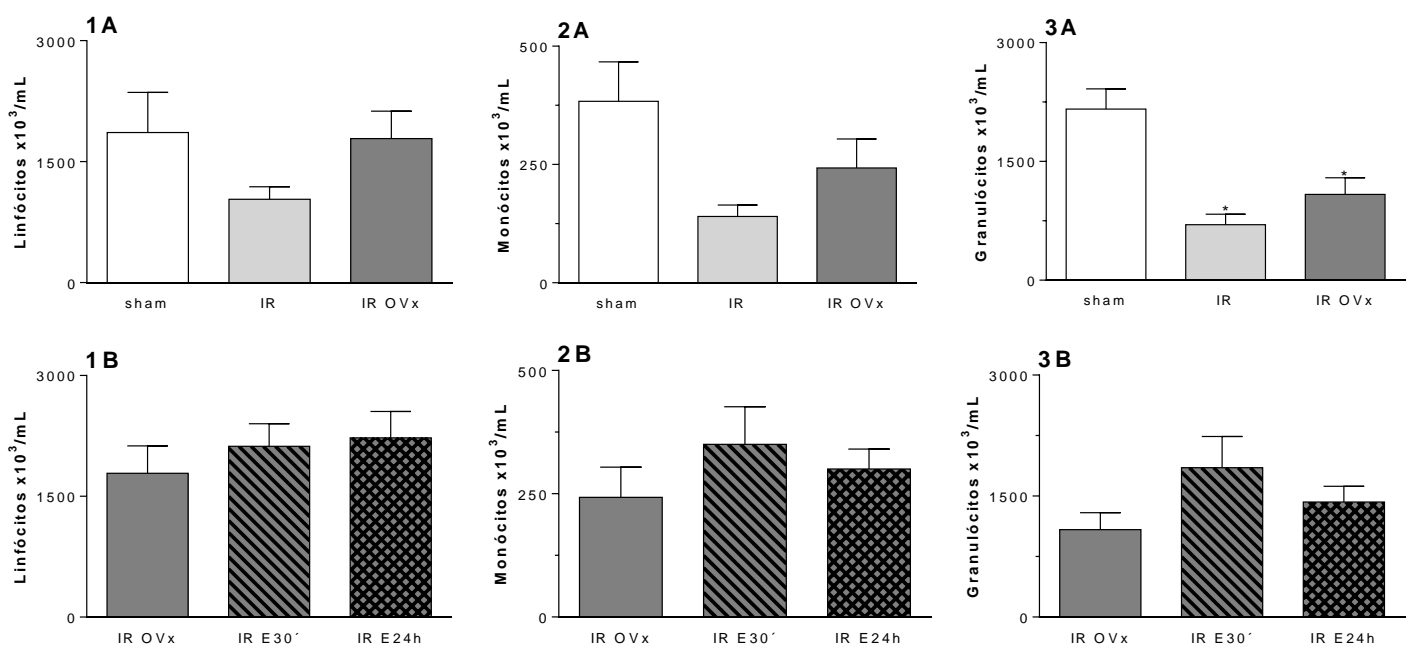

Após analisado a quantidade de líquido intestinal e a quantidade presente de células, quantificamos também a concentração de algumas citocinas presentes no líquido intestinal. A figura 16 representa a concentração de IL-10 (painéis $A$ e B) e de CINC-1 (painéis C e D) quantificadas no fluido intestinal recuperado da embalagem plástica. A IR intestinal não induziu aumento significativo de IL-10 intestinal em ambos os grupos de animais, isto é, com e sem ovários. Todavia animais OVx revelaram maior tendência, mas não significativa, de geração dessa citocina. Por outro lado, animais do grupo OVx tratados com estradiol 30 min após o início da isquemia tiveram aumento significativo na concentração de IL-10.

Em relação à CINC-1, nossos dados evidenciaram redução de sua concentração após a indução da IR intestinal nos animais com ovários intactos em comparação ao grupo de animais falsamente operado (sham). 
Figura 16 - Concentração de IL-10 (A e B) e CINC-1 (C e D) no fluido ascítico intestinal recuperado da embalagem plástica dos ratos após a IR intestinal. As ratas OVx ou não foram submetidas ou não

(Sham) à isquemia (45 min) e reperfusão intestinal (2 horas - IR intestinal). A administração de estradiol foi realizada com 30 min de isquemia ou $24 \mathrm{~h}$ antes da isquemia com a mesma dosagem $(280 \mu \mathrm{g} / \mathrm{kg})$. Os dados representam a média \pm EPM de 8 a 12 amostras. ${ }^{*} P<0,05$ em relação ao grupo sham; $\alpha P<0,05$ em relação ao grupo IR não $\mathrm{OVx} ; \mu P<0,05$ em relação ao grupo IR $\mathrm{OVx}$.
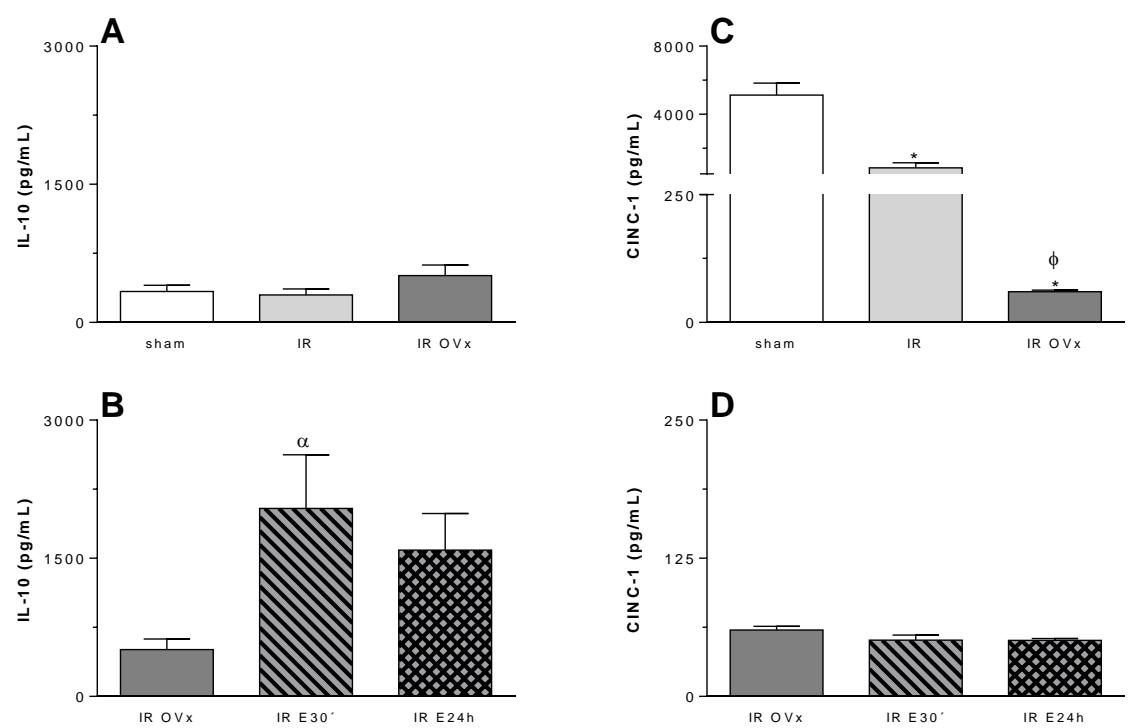

\subsubsection{Perfil gênico inflamatório e da sinalização induzida pelo estradiol no mesentério}

A artéria mesentérica superior irriga todo o intestino e, portanto, sua obstrução afeta diretamente a homeostasia do trato gastrintestinal. Diversos estudos indicam que o intestino pode ser considerado o motor da inflamação sistêmica e daquela observada em órgãos distantes (como o pulmão). A percepção que se tem é a de que o intestino sob o estresse da IR gera mediadores inflamatórios que podem ser disseminados para a corrente sanguínea, linfática e assim causar uma estimulação generalizada, mas que pode seguir um curso diferente. Com base nestas evidências, consideramos investigar se fêmeas sob o estresse IR intestinal teriam diferenças na expressão gênica de mediadores da inflamação. Nesta etapa tivemos como meta fazer uma varredura de genes que podem ser estimulados ou reprimidos pela IR intestinal. Sendo assim os dados a serem apresentados apresentam um panorama do perfil gênico inflamatório. De interesse, estes estudos permitirão a incorporação de futuros estudos acerca do papel mais pontual de um ou de um grupo de genes relacionados a modulação da inflamação após a IR intestinal.

Portanto, analisamos o efeito da IR intestinal sobre a expressão gênica, utilizando uma seleção de genes (perfil inflamatório) entre os grupos de fêmeas 
ovariectomizadas (OVx) e aquelas mantidas com os ovários intactos (Não OVx). Nossos resultados estão apresentados na figura 17 e no quadro inserido ao lado da figura. Em ambos (gráfico e quadro) o Group 1 está representado pelas grupo IR OVx e o Control Group nomeia as fêmeas IR.

De maneira a facilitar a apresentação dos dados optamos por inserir cada gráfico gerado ladeado, quando obtivermos diferenças significativas, por um quadro indicando o gene alterado, o nível de variação (positiva ou negativa) e o valor correspondente à significância ("P"). Para efeitos de compreensão dos gráficos e do quadro, vale lembrar que as cores dos pontos representam genes upregulated, unchanged ou downregulated no mesentério dos animais submetidos a IR intestinal. Os grupos de estudo descritos no gráfico serão mencionados a cada descrição de resultados. Os dados apresentados nos quadros representam a comparação do grupo da esquerda $X$ grupo da direita.

Como pode ser observado somente o gene para Ccr4 nas fêmeas OVx é que foi significativamente upregulated em relação às fêmeas com ovários intactos (Não OVx).

Figura 17 - Análise do perfil inflamatório gênico (RTPCR) no mesentério de fêmeas com ovários intactos (Não OVx) e removidos (OVx) após serem submetidas a IR intestinal. Os dados estão representados no quadro ao lado da figura e mostram a variação da expressão de genes analisadas em 4 amostras de mesentério por grupo. Valores de $P<0,05$ foram considerados e descritos no quadro.

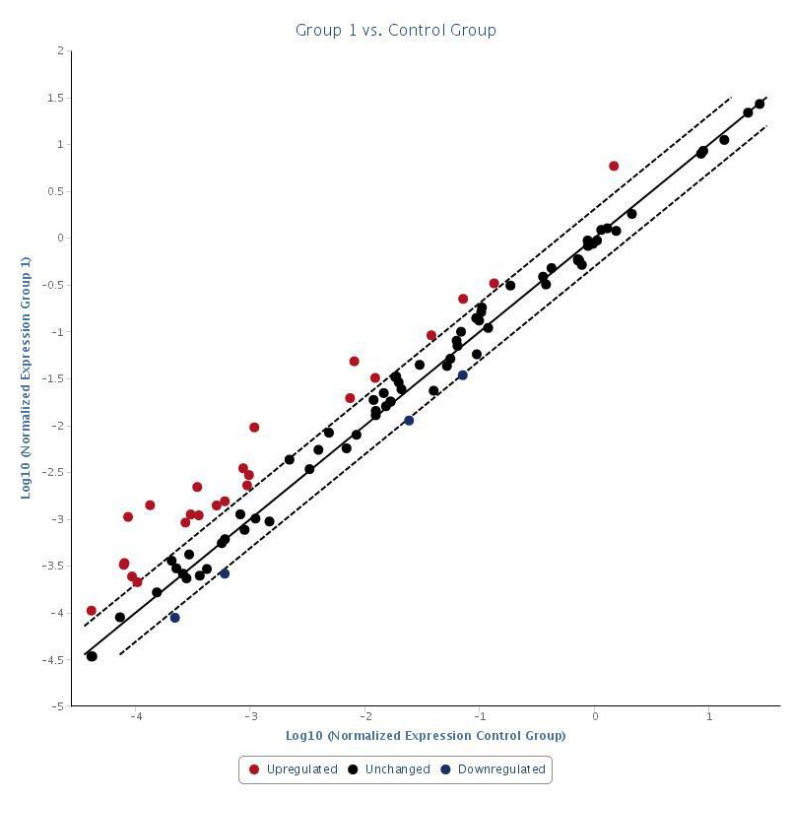

IR OVx x IR

\begin{tabular}{|l|r|r|}
\hline gene & variação & valor de $P$ \\
\hline Ccr4 & 4,14 & 0,0363 \\
\hline
\end{tabular}


A seguir, com o objetivo de avaliar os efeitos do estradiol sobre a expressão gênica no mesentério, fêmeas $O V x$ foram tratadas com estradiol $24 \mathrm{~h}$ antes da indução da IR intestinal e a expressão gênica comparada em relação a fêmeas OVx.

A figura 18 representa o perfil obtido onde o Group 1 é representado pelas fêmeas OVx tratadas com E24 h (IR E24h) em relação a fêmeas IR OVx não tratadas identificadas como Control Group. O quadro ao lado mostra a variação da expressão gênica das fêmeas E24h em relação às OVx (não tratadas).

Os dados indicaram que apenas dois genes tiveram sua expressão significativamente modificada em fêmeas $\mathrm{OVx}$ tratadas com estradiol quando comparada com a expressão de genes no mesentério de fêmeas $O V x$ não tratadas. Nesse sentido observamos que a expressão de Mif foi reduzida em 2,28 vezes e a de RGD1561905 predicted aumentou 2,18 vezes.

Figura 18 - Análise do perfil inflamatório gênico (RTPCR) no mesentério de fêmeas com ovários removidos (OVx) após serem submetidas a IR intestinal. O grupo E24h trata-se de animais que receberam tratamento com estradiol $(280 \mu \mathrm{g} / \mathrm{kg}$, s.c.) $24 \mathrm{~h}$ antes da IR intestinal (Group 1$)$. Os dados estão representados no quadro ao lado da figura e mostram a variação da expressão de genes analisados em 4 amostras de mesentério por grupo. Valores de $P<0,05$ foram considerados e descritos no quadro.

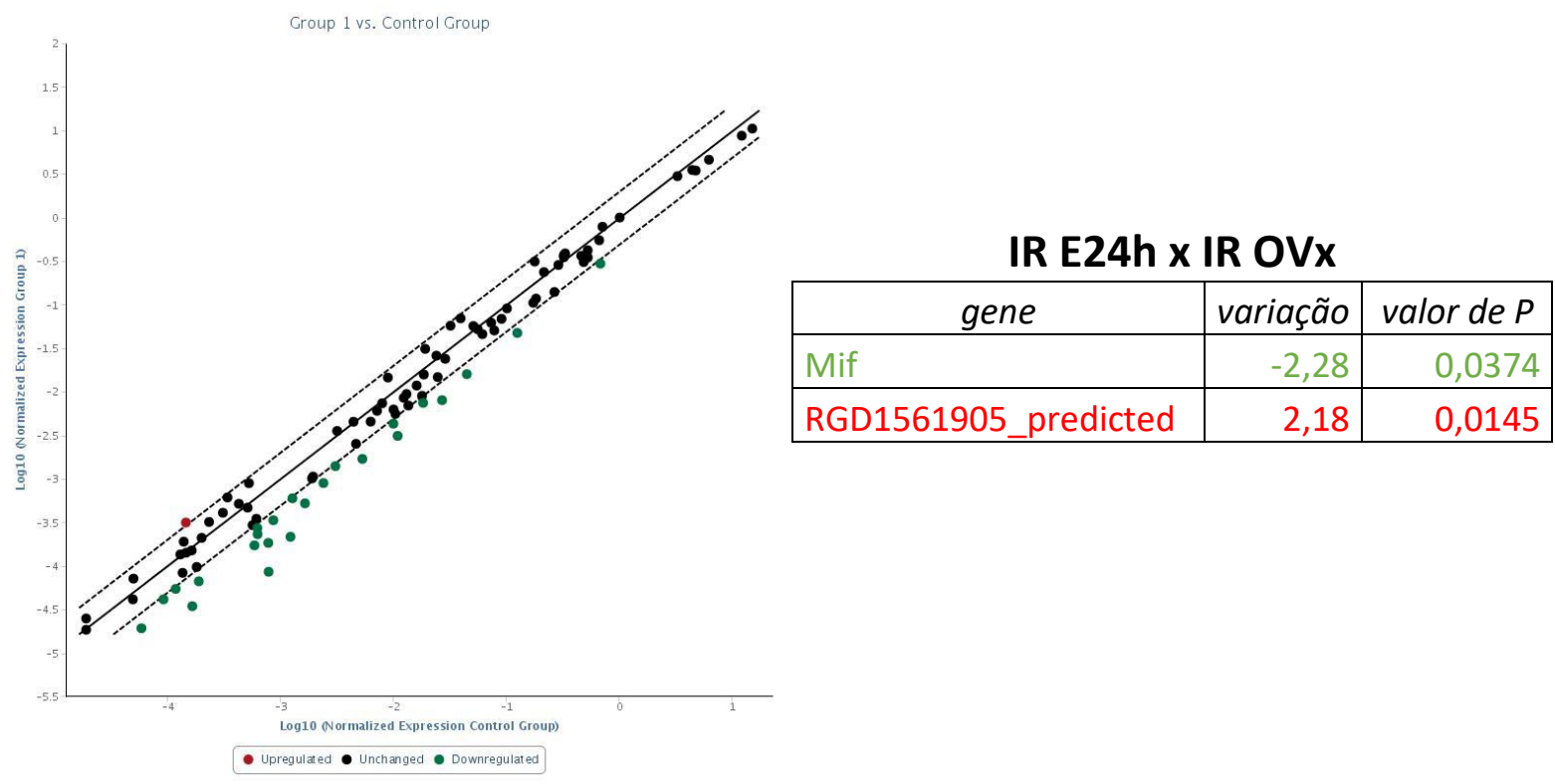

$\mathrm{Na}$ sequência comparamos o perfil gênico inflamatório no mesentério de fêmeas com ovários intactos após serem submetidas a IR intestinal com o de fêmeas OVx tratadas estradiol $24 \mathrm{~h}$ (E24h). A base para estes estudos foi verificar se tratamento com estradiol poderia de alguma forma deslocar o perfil gênico das ratas 
OVx para um perfil similar ao observado nos animais com os ovários intactos. Nossos dados indicaram que sugerindo que o estradiol administrado $24 \mathrm{~h}$ antes da indução da IR intestinal de alguma forma foi eficaz em alterar a expressão gênica para o perfil de fêmeas intactas, justificando assim a homogeneidade da expressão entre os grupos (dados não mostrados).

Portanto, avaliamos a expressão de genes no mesentério de em fêmeas OVx (Group 1) e comparamos com o observado naquelas com os ovários intactos (Não OVx - Control Group) após a IR intestinal. Os dados gerados indicaram que não houve alteração significativa.

Figura 19 - Análise do perfil gênico de estradiol (RTPCR) no mesentério de fêmeas com ovários removidos (OVx - Group 1) e intacto (Control Group) após serem submetidas a IR intestinal. Dados foram obtidos em 4 amostras de mesentério por grupo.

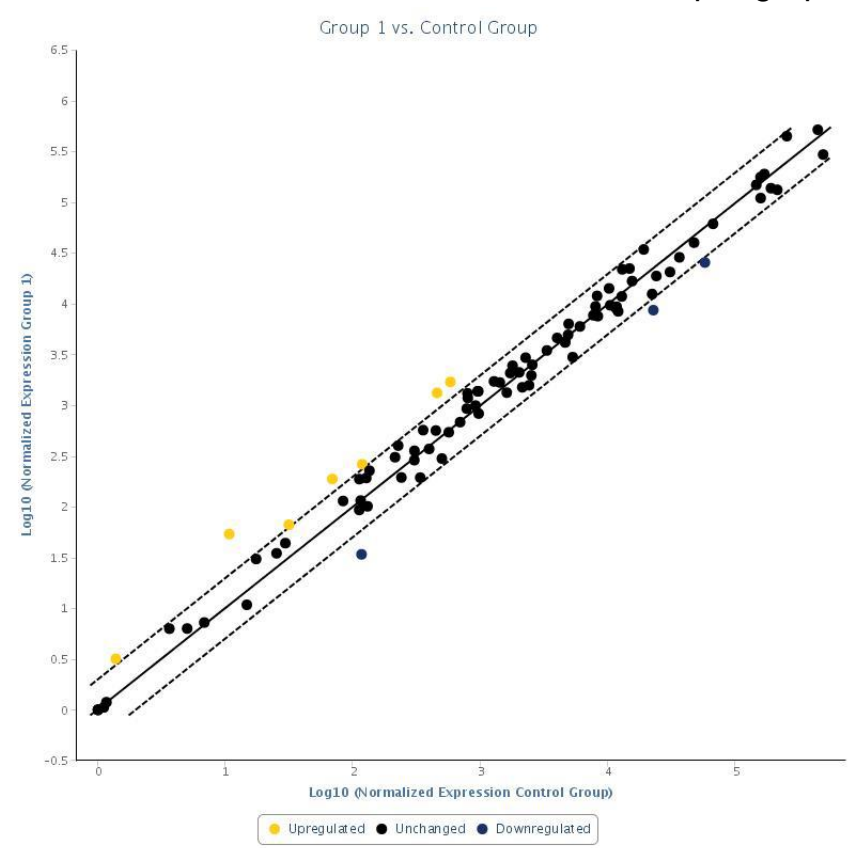

Para finalizar esta fase dos estudos e tendo como objetivo a obtenção de informações sobre o papel do estradiol na sinalização de genes nos animais OVx, optamos por fazer a análise no mesentério de animais OVx tratados com estradiol 24 h antes (E24h) da indução da IR intestinal. Os dados estão apresentados na figura 20 sendo o Group 1 e Control Group identificados como OVx tratados com E24h e OVx não tratados, respectivamente. 
Figura 20 - Análise do perfil gênico de estradiol (RTPCR) no mesentério de fêmeas com ovários removidos $(\mathrm{OVx})$ após serem submetidas a IR intestinal. O grupo E24h trata-se de animais que receberam tratamento com estradiol $(280 \mu \mathrm{g} / \mathrm{kg}$, s.c.) $24 \mathrm{~h}$ antes da IR intestinal. Os dados estão representados no quadro ao lado da figura e mostram a variação da expressão de genes analisados em 4 amostras de mesentério por grupo. Valores de $P<0,05$ foram considerados e descritos no quadro.

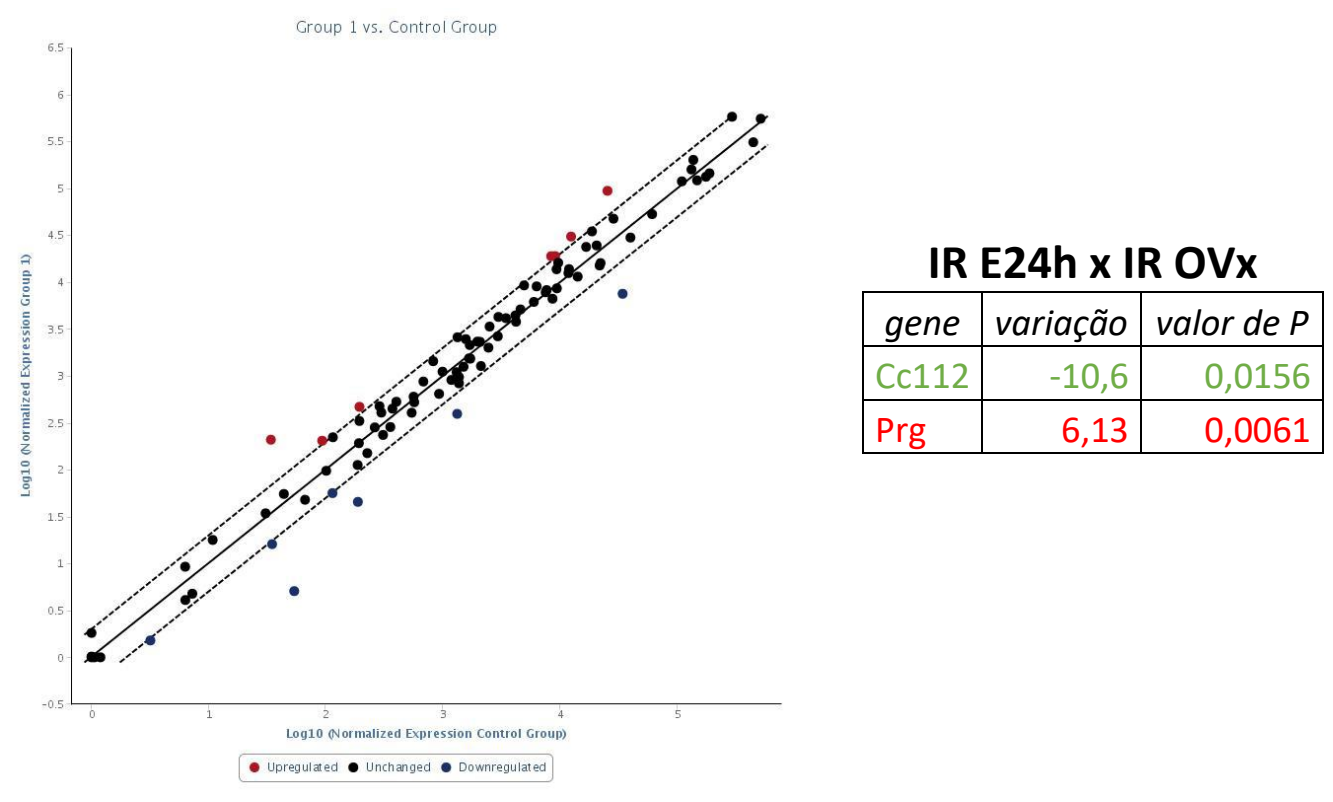

Os resultados apresentados no quadro ao lado da Figura 20 mostram que o estradiol administrado $24 \mathrm{~h}$ antes determinou downregulation de Ccl12 em relação às fêmeas $O V x$ não tratadas e paralelamente houve upregulation para genes relacionados ao receptor de progesterona. Nessa linha de raciocínio, os dados apresentados na Figura 21 revelaram que fêmeas OVx tratadas com estradiol $24 \mathrm{~h}$ antes da IR intestinal (Group 2) não apresentaram alteração de perfil de sinalização de genes sensíveis ao estradiol quando comparadas com a fêmeas com ovários intactos (Control Group). Estes dados analisados à luz dos dados gerados na Figura 25, podem indicar que o tratamento de fêmeas OVx com o estradiol normalizou a sinalização do estradiol aos genes sensíveis, de maneira que ocorre semelhança na sinalização entre os grupos estudados. Portanto, durante a IR intestinal o estradiol administrado previamente recupera a sinalização aos genes sensíveis gerando um perfil de expressão similar às fêmeas não OVx o qual pode, eventualmente, se associar aos mecanismos protetores do estradiol na inflamação causada pela IR intestinal. 
Figura 21 - Análise do perfil gênico de estradiol (RTPCR) no mesentério de fêmeas com ovários intactos após serem submetidas a IR intestinal. O grupo E24h trata-se de fêmeas com ovários removidos que receberam tratamento com estradiol $(280 \mu \mathrm{g} / \mathrm{kg}$, s.c.) $24 \mathrm{~h}$ antes da IR intestinal.

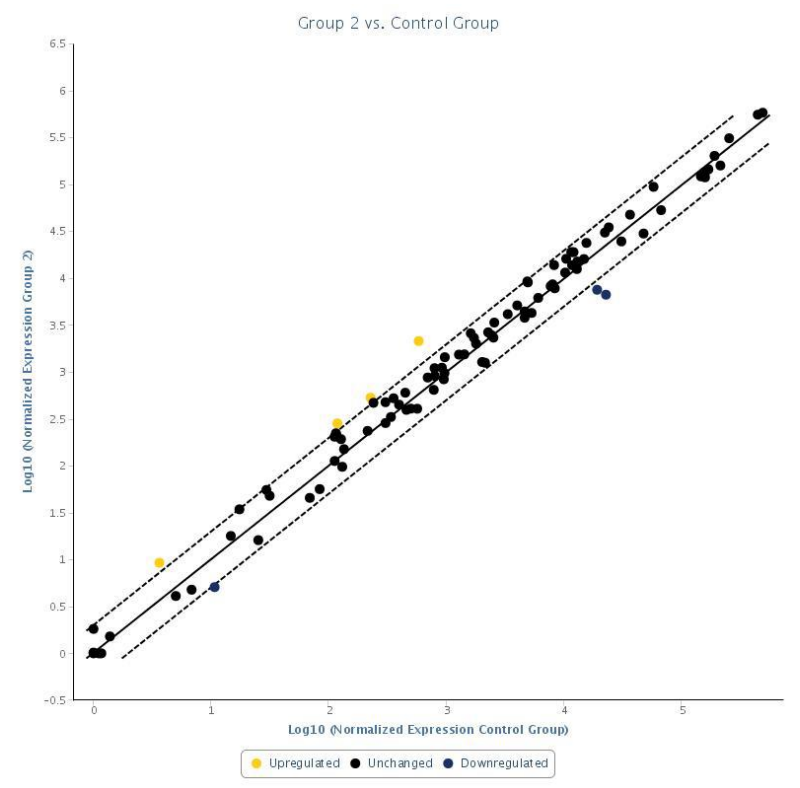

\subsection{Efeito da IR intestinal sobre a inflamação sistêmica}

\subsubsection{Número de leucócitos e plaquetas circulantes}

Dando sequência aos estudos e os direcionando para os efeitos sistêmicos da IR intestinal em fêmeas, avaliamos os leucócitos circulantes nesses animais. A tabela 1 representa a contgem total dos leucócitos e a figura 22, a contagem diferencial de leucócitos e de plaquetas circulantes. Nossos estudos mostraram que houve aumento no número de leucócitos circulantes após a IR intestinal quando comprados aos valores iniciais. Os animais do grupo IR apresentaram, após a IR intestinal, número de leucócitos 2 vezes maior do que o apresentado no grupo IR OVx.

Em relação aos tratamentos dos animais com estradiol, observamos que o índice de aumento não foi tão elevado quando comparado ao grupo de animais com os ovários intactos. De fato, as porcentagens nesses grupos foram de $44,58 \%$ e 90,4\%, respectivamente. Contudo, animais OVx tratados com estradiol $24 \mathrm{~h}$ antes do início da IR intestinal apresentaram maior aumento no recrutamento de leucócitos em comparação ao grupo OVx e ao tratado com estradiol 30 min. 
Tabela 1. Contagem total de leucócitos no sangue de ratas submetidas à isquemia (45min) e reperfusão intestinal (2 horas - IR intestinal). Os grupos consistiram de animais com ou sem ovários e, animais tratados com estradiol (30min depois ou $24 \mathrm{~h}$ antes da isquemia), falsamente operados (Sham). Também apresentamos dados de animais não manipulados (basal).

Índice de aumento do

Inicial

Final número de leucócitos (\%)

\begin{tabular}{lccc}
\hline Basal & $8354 \pm 729$ & - & - \\
Sham & $10477 \pm 960,8$ & $9173 \pm 728,4$ & - \\
IR & $6627 \pm 601,3$ & $15147 \pm 1392^{*}$ & 128,56 \\
IR OVx & $11427 \pm 801,9$ & $18250 \pm 2033^{*}$ & 59,7 \\
IR E30' & $9150 \pm 692,2$ & $16150 \pm 2371^{*}$ & 44,58 \\
IR E24h & $11117 \pm 964,5$ & $21167 \pm 2029^{*}$ & 90,4 \\
\hline
\end{tabular}

Os dados representam a média \pm EPM de 5-17 experimentos. ${ }^{*} P<0.05$ em relação ao valor inicial do experimento de cada grupo.

A figura 22 representa os diferentes tipos celulares quantificados no sangue entre o período de início e fim do experimento. O número de linfócitos estava reduzido no grupo de animais sham e elevado nos OVx IR intestinal. Por outro lado, em animais OVx tratados com estradiol os leucócitos não sofreram alteração (Painel A). Com respeito ao número de monócitos, nossos dados também mostraram que o número dessas células reduziu no grupo sham e aumentou após a IR intestinal nos animais com ovários e nos animais OVx tratados com estradiol (30 min ou 24 h). Já nos animais OVx IR intestinal a quantidade de monócitos não se alterou (Painel B). Em relação aos granulócitos, ilustrados no painel $\mathrm{C}$, observamos que após submeter os animais a IR intestinal houve aumento do número destas células. O tratamento com estradiol durante a isquemia reverteu este aumento. Por fim no painel $D$, notamos que o tratamento com estradiol induziu aumento no número de plaquetas. 
Figura 22 - Contagem diferencial dos leucócitos circulantes: linfócitos (A), monócitos (B), granulócitos (C) e plaquetas (D) em ratas submetidos a IR intestinal. Os animais foram submetidos à isquemia (45min) e reperfusão intestinal (2 horas - IR intestinal). Os grupos consistiram de animais com ou sem ovários, e tratados com estradiol (30min depois ou $24 \mathrm{~h}$ antes da isquemia), falsamente operados

(Sham) e animais não manipulados (Basal). Os dados representam a média \pm EPM de 6-17 experimentos. ${ }^{*} P<0.05$ em relação ao valor inicial do experimento de cada grupo; ${ }^{\alpha} \mathrm{P}<0.05$ em relação ao grupo Sham; ${ }^{\Phi} \mathrm{P}<0.05$ em relação ao grupo IR não $\mathrm{OVx}$; ${ }^{\mu \mathrm{P}}<0.05$ em relação ao grupo IR $\mathrm{OVx}$.
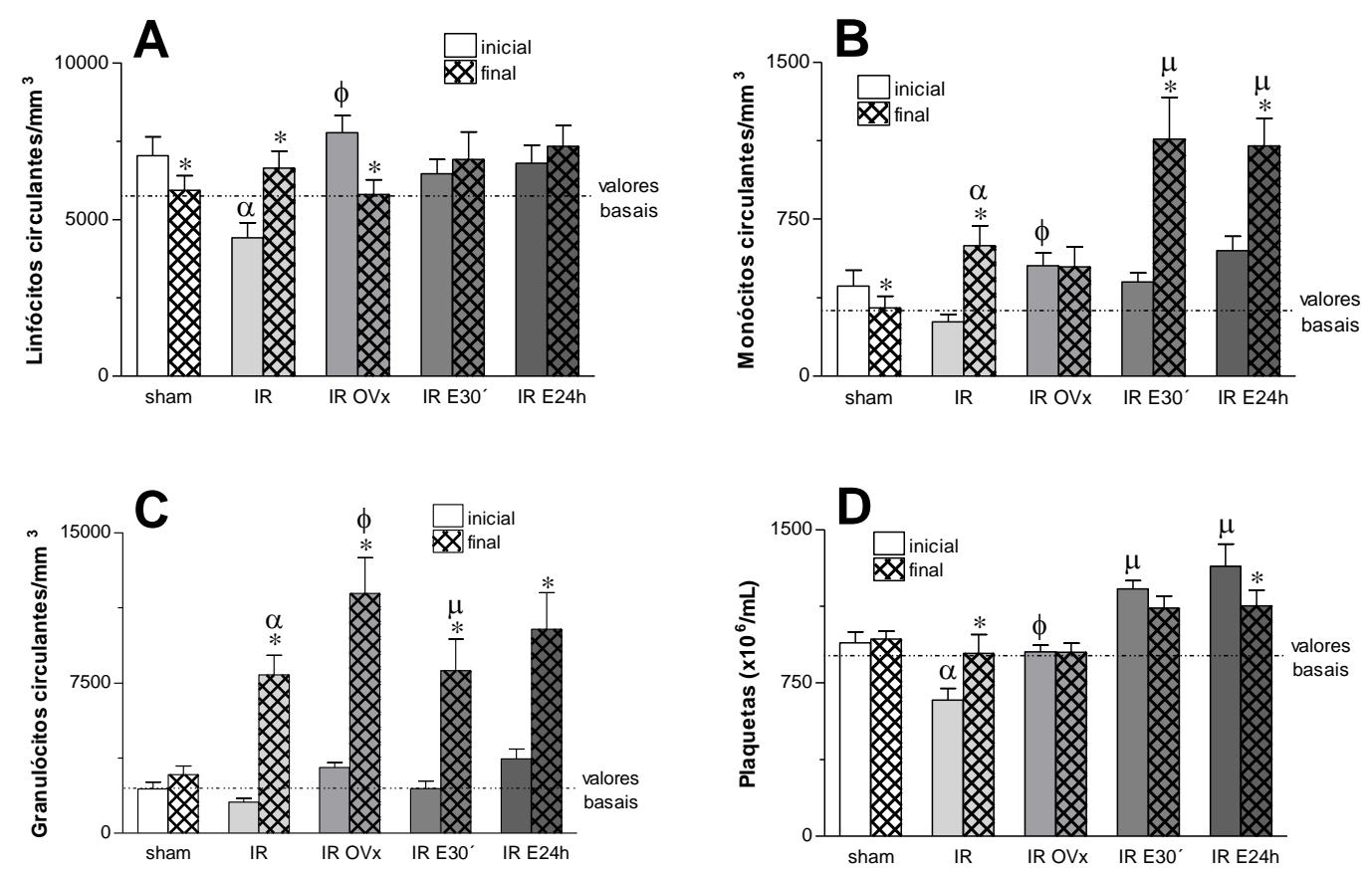

\subsubsection{Células quantificadas na medula óssea}

$\mathrm{Na}$ medida em que avaliamos os leucócitos circulantes, o passo seguinte foi analisar o compartimento medular desses animais. A quantificação do número de células totais recuperadas no lavado da medula óssea está representada na figura 23. Os valores obtidos indicaram que a IR intestinal causou redução significativa do número total de células recuperadas no lavado medular quando comparado ao obtido nas amostras dos animais do grupo sham. Por outro lado, a remoção dos ovários (IR OVx) aumentou o número de células quantificadas na medula óssea. Os dois protocolos de tratamentos dos animais com estradiol não alteraram esse fenômeno. 
Figura 23 - Número total de leucócitos na medula óssea em grupos de ratas ovariectomizadas (OVx) ou não (não OVx) após submetidas a IR intestinal. Os grupos consistiram de animais tratados com estradiol (30min depois ou 24h antes da isquemia), falsamente operados (Sham) e animais não manipulados (Basal). Os dados representam a média \pm EPM de 6-17 experimentos. ${ }^{*} P<0,05$ em relação ao grupo Sham, ${ }^{\Phi} P<0,05$ em relação ao grupo IR não OVx.
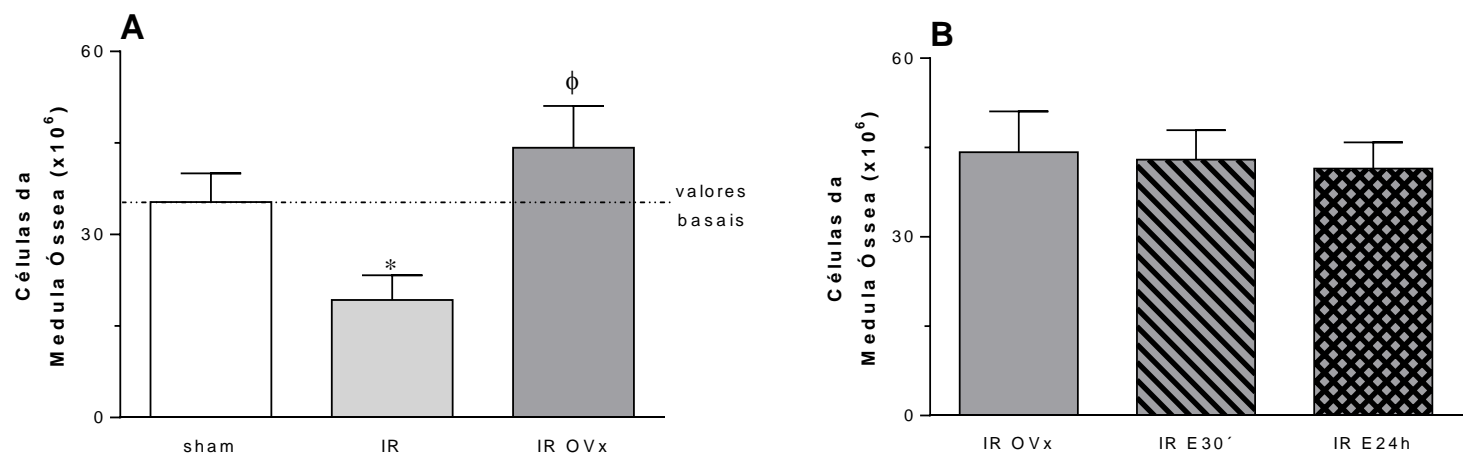

\subsubsection{Migração in vitro de neutrófilos circulantes}

A figura 24 representa o número de neutrófilos migrados espontaneamente em placas de quimiotaxia. Como pode ser observado, neutrófilos de animais OVx submetidos a IR intestinal apresentaram aumento significativo da migração em relação ao observados nos neutrófilos de animais IR intestinal com ovários intactos. Estes por sua vez não apresentaram maior índice de migração quando comparados os neutrófilos migrados do grupo sham. Ambos os protocolos de tratamentos dos animais com estradiol foram efetivos em reduzir a migração.

Figura 24 - Ensaio de migração de neutrófilos circulantes de ratas OVx ou não que foram submetidas ou não (sham) à isquemia (45 min) e reperfusão intestinal (2 horas - IR intestinal). A administração de

estradiol foi realizada com $30 \mathrm{~min}$ de isquemia ou $24 \mathrm{~h}$ antes da isquemia com a mesma dosagem $(280 \mu \mathrm{g} / \mathrm{kg})$. Os dados representam a média \pm EPM de 6 a 9 amostras. ${ }^{*} P<0,01$ em relação ao grupo sham; ${ }^{\Phi} P<0,05$ em relação ao grupo IR; ${ }^{a} P<0,001$ em relação ao grupo IR $O V x$.
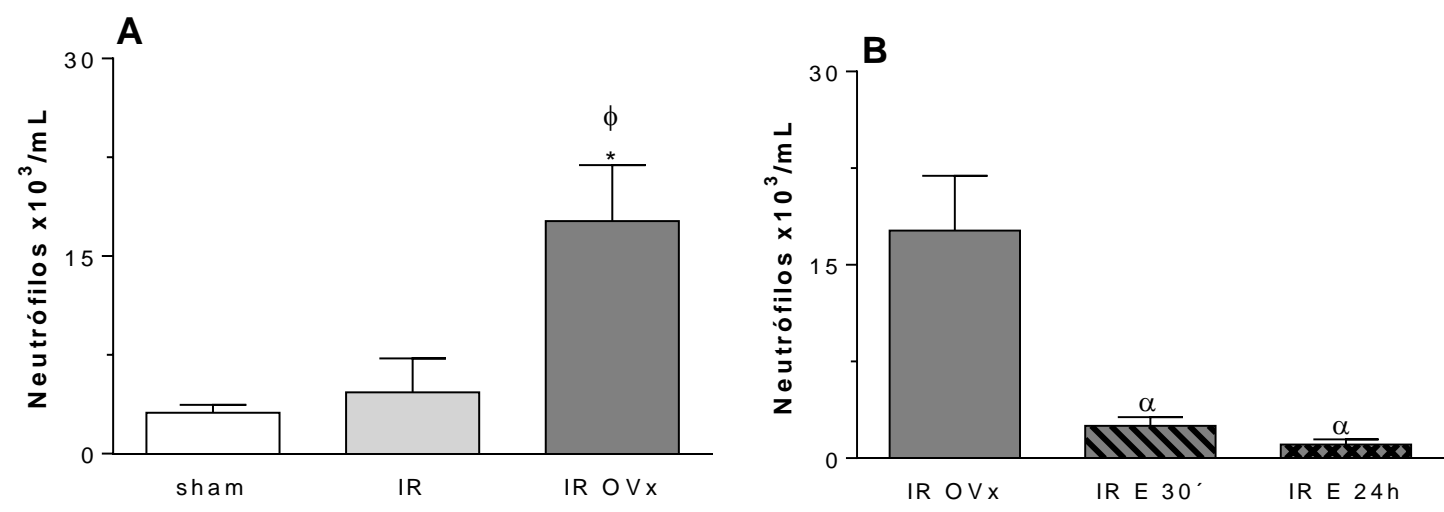


\subsubsection{Concentração sistêmica de mediadores inflamatórios}

Os dados a seguir se referem a concentração de mediadores inflamatórios quantificados em amostras de soro obtidas de animais submetidos à IR intestinal. Estes dados podem nortear os sinais inflamatórios gerados durante o evento e então, nos indicar quais deles estariam envolvidos no mecanismo estudado.

$\rightarrow \underline{\text { Interleucinas (IL) }}$

A figura 25 mostra que a concentração de IL-10 (painel A) aumentou sua concentração nos animais OVx submetidos a IR intestinal em relação ao grupo sham. O tratamento dos animais com estradiol (painel B) não alterou a concentração de IL10. A concentração de IL-1 $\beta$ não foi modificada em nenhum dos grupos estudados (painel C e D).

Figura 25 - Concentração sérica de IL-10 (painel A e B) e IL-1 $\beta$ (painel C e D) em ratas OVx ou não que foram submetidas ou não (sham) à isquemia $(45 \mathrm{~min}$ ) e reperfusão intestinal (2 horas - IR intestinal). A administração de estradiol foi realizada com $30 \mathrm{~min}$ de isquemia ou $24 \mathrm{~h}$ antes da isquemia com a mesma dosagem $(280 \mu \mathrm{g} / \mathrm{kg})$. Os dados representam a média $\pm E P M$ de 6 a 9 amostras. ${ }^{*} P<0,05$ em relação ao grupo sham.
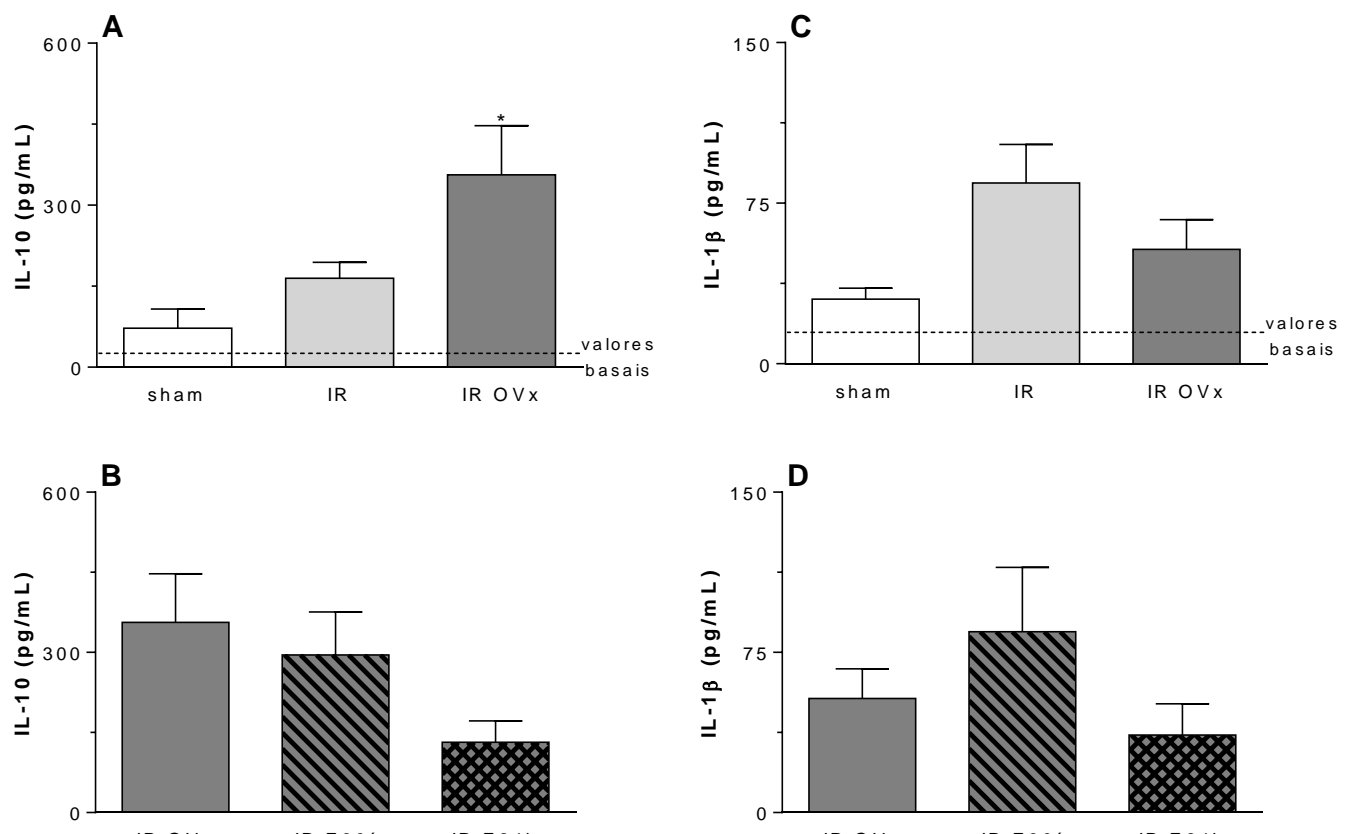

IR OVx

IR E30

IR E24h 
$\rightarrow$ Fator de Crescimento Endotelial Vascular (VEGF)

Nossos dados indicaram que a IR intestinal não alterou a concentração de VEGF no soro dos animais (figura 26, painel A). O mesmo foi observado nas amostras de soro dos animais tratados com estradiol nos dois protocolos (figura 26, painel B).

Figura 26 - Concentração sérica de VEGF em ratas OVx ou não que foram submetidas ou não (sham) à isquemia (45 min) e reperfusão intestinal (2 horas - IR intestinal). A administração de estradiol foi realizada com 30 min de isquemia ou $24 \mathrm{~h}$ antes da isquemia com a mesma dosagem $(280 \mu \mathrm{g} / \mathrm{kg})$. Os dados representam a média \pm EPM de 6 a 9 amostras.
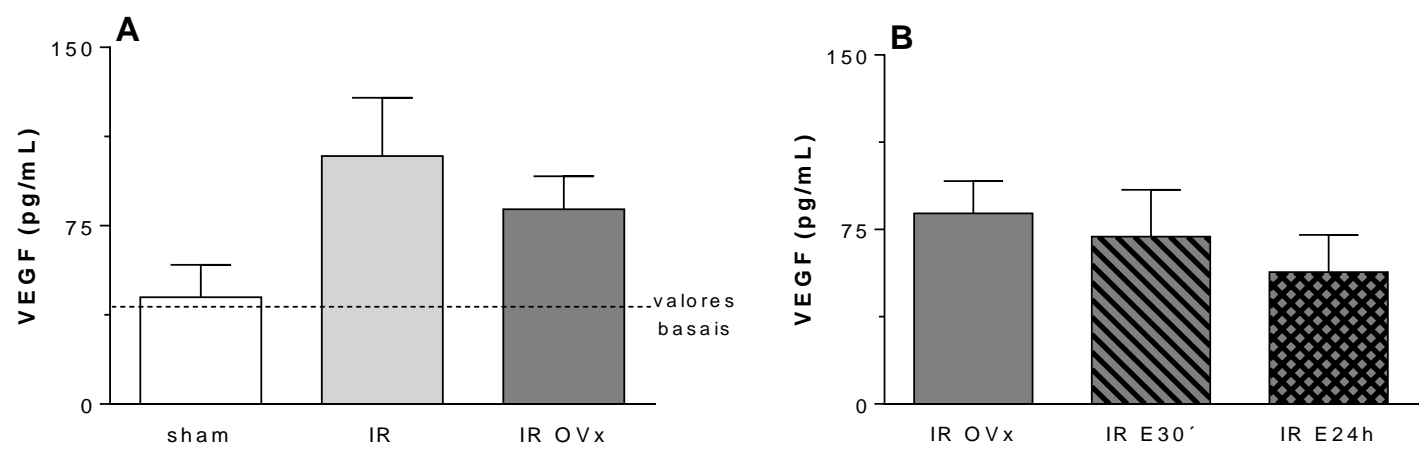

$\rightarrow$ Quimiocinas:

- Proteínas Inflamatórias Macrofágicas (MIP)

Os dados apresentados na figura 27 (painel A - D) mostraram que as concentrações de MIP-1 $\alpha$ e MIP-2 elevaram de forma significativa após a IR intestinal nos animais OVx (painéis $\mathrm{A}$ e $\mathrm{C}$ ). Além disso, o tratamento dos animais com estradiol $24 \mathrm{~h}$ antes da indução da isquemia, mas não 30 min após a isquemia, foi efetivo em reduzir de forma significativa o efeito da IR intestinal sobre a geração de MIP-1 $1 \alpha$ e MIP-2 (painéis B e D). 
Figura 27 - Concentração sérica de MIP-1a (painel A e B) e MIP-2 (painel C e D) em ratas OVx ou não que foram submetidas ou não (sham) à isquemia ( $45 \mathrm{~min})$ e reperfusão intestinal (2 horas - IR intestinal). A administração de estradiol foi realizada com 30 min de isquemia ou $24 \mathrm{~h}$ antes da isquemia com a mesma dosagem $(280 \mu \mathrm{g} / \mathrm{kg})$. Os dados representam a média \pm EPM de 6 a 9 amostras. Painel A: ${ }^{*} P<0,05$ em relação ao grupo sham; ${ }^{\Phi} P<0,05$ em relação ao grupo IR. Painel C: ${ }^{*} P<0,01$ em relação ao grupo sham; ${ }^{\Phi} P<0,01$ em relação ao grupo IR. Painéis $\mathrm{B}$ e $\mathrm{D}$ : ${ }^{\alpha} P<0,05$ em relação ao grupo IR OVx.
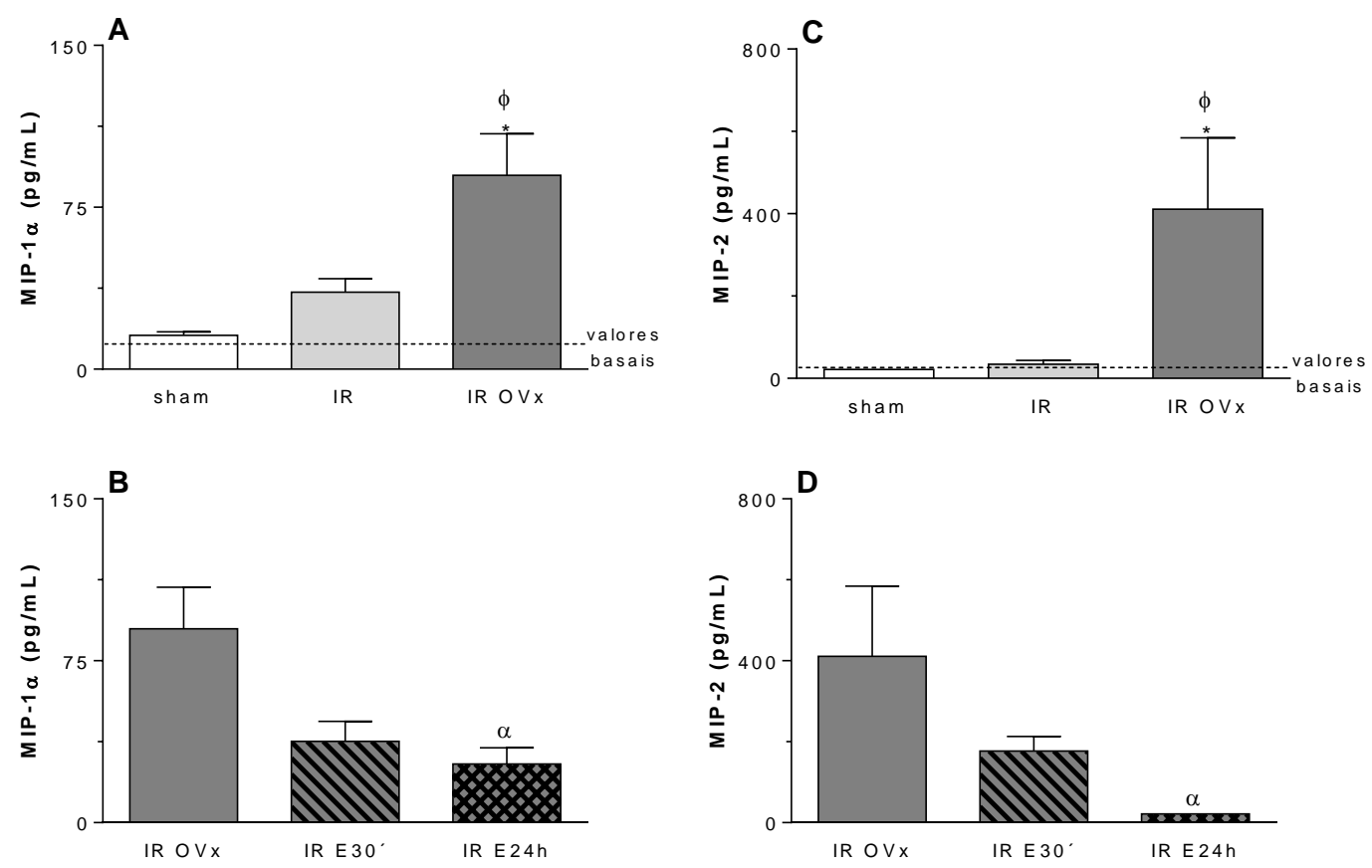

- MCP-1, CINC-1, RANTES, IP-10 e leptina

No painel A da figura 28, observamos que a MCP-1 encontra-se em maior quantidade nos animais IR OVx e que apenas o tratamento com estradiol 24h antes da indução da IR intestinal preveniu este aumento (painel B).

Por outro lado, nos painéis $C$ e $D$, o CINC-1, observamos aumento somente pela manipulação do intestino. Mesmo assim, animais $\mathrm{OVx}$ após a IR intestinal mostraram valores ainda mais elevados quando comparado ao grupo falso operado (Sham). Além disso, ao tratarmos os animais com estradiol no grupo IR E24h observamos redução do CINC-1 em comparação ao grupo IR OVx, o que não foi observado quando tratamos os animais com estradiol 30 min após a indução da isquemia (IR E30').

Com respeito a concentração de RANTES, nossos revelaram que a IR intestinal não alterou a sua concentração (painel E). Apesar do mencionado, o tratamento dos animais com estradiol 30 min após o início da isquemia (IR E 30') foi efetivo em aumentar a concentração desta quimiocina (painel F). 
Figura 28 - Concentração sérica de MCP-1 (painel A e B), CINC-1 (painel C e D) e RANTES (painel E e $F$ ) em ratas $O V x$ ou não que foram submetidas ou não (sham) à isquemia (45 min) e reperfusão intestinal (2 horas - IR intestinal). A administração de estradiol foi realizada com 30 min de isquemia ou $24 \mathrm{~h}$ antes da isquemia com a mesma dosagem $(280 \mu \mathrm{g} / \mathrm{kg})$. Os dados representam a média \pm EPM de 6 a 9 amostras. ${ }^{*} P<0,05$ em relação ao grupo sham; ${ }^{\Phi} P<0,01$ em relação ao grupo IR; $\alpha P<0,05$ em relação ao grupo IR OVx.
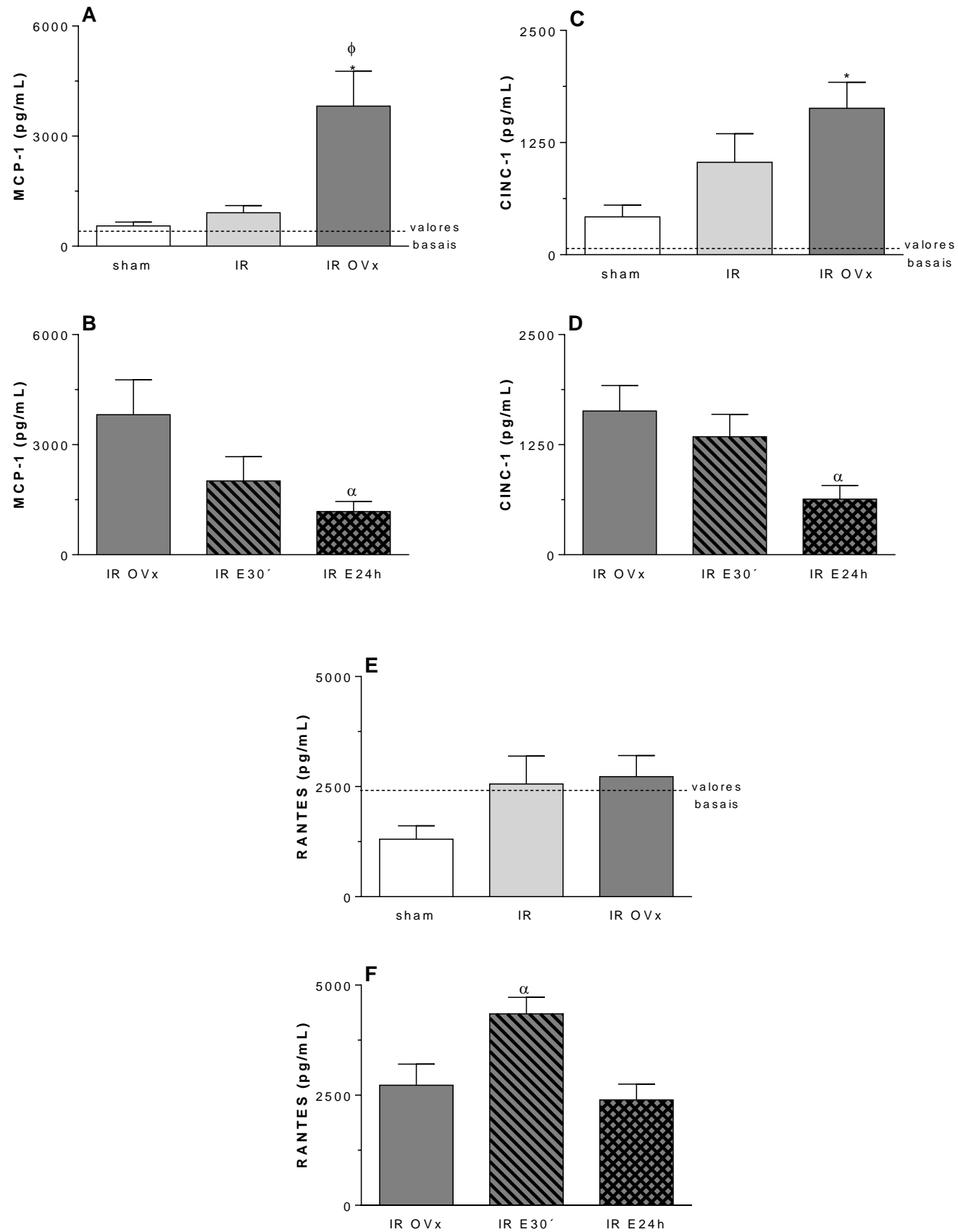

Nossos dados indicaram que a concentração de IP-10 aumentou após a IR intestinal tanto em animais com ou sem ovários (Figura 29, painel A). Ainda, o tratamento dos animais previamente (IR E24h) ou agudamente (IR E30'), reduziram os níveis de IP-10 no soro dos animais em relação ao grupo IR OVx (painel B). 
Figura 29. Concentração sérica de IP-10 em ratas OVx ou não que foram submetidas ou não (sham) à isquemia (45 min) e reperfusão intestinal (2 horas - IR intestinal). A administração de estradiol foi realizada com $30 \mathrm{~min}$ de isquemia ou $24 \mathrm{~h}$ antes da isquemia com a mesma dosagem $(280 \mu \mathrm{g} / \mathrm{kg})$. Os dados representam a média \pm EPM de 6 a 9 amostras. " $P<0,05$ IR em relação ao grupo sham;

${ }^{*} P<0,001$ IR OVx em relação ao grupo sham; ${ }^{\alpha} P<0,05$ em relação ao grupo IR OVx.
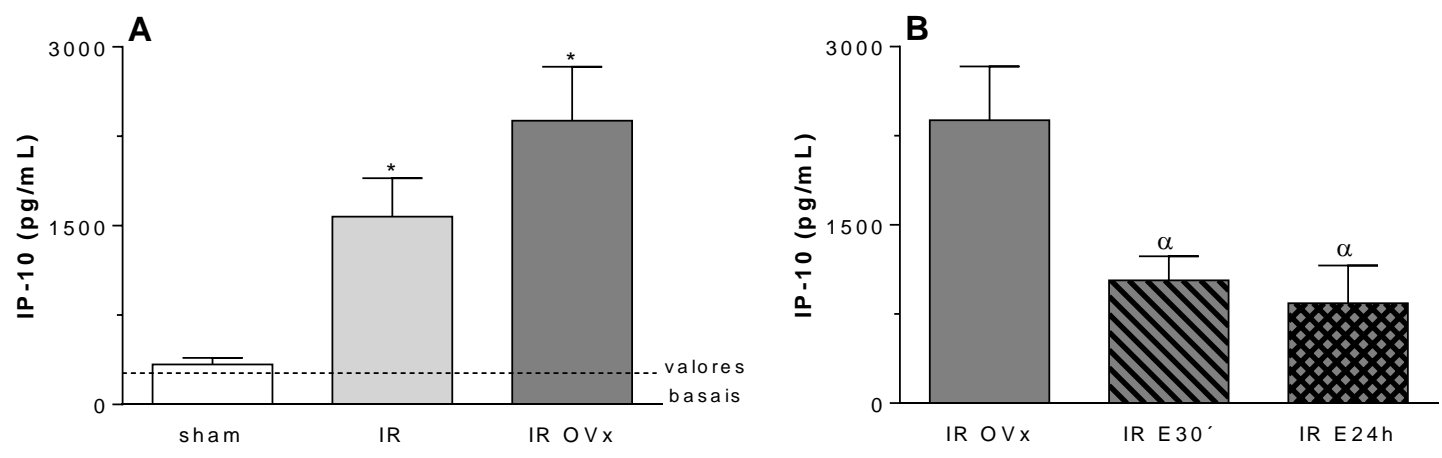

A figura 30 mostra que a IR intestinal em animais OVx induziu a um significativo aumento de leptina quando comparado com os valores encontrados no soro dos animais do grupo IR (ovários intactos) e sham (painel A). O tratamento dos animais com estradiol (painel B) foi efetivo em reduzir o aumento de leptina tanto no grupo IR E30' como no IR E24h.

Figura 30 - Concentração sérica de leptina em ratas OVx ou não que foram submetidas ou não

(sham) à isquemia (45 min) e reperfusão intestinal (2 horas - IR intestinal). A administração de estradiol foi realizada com 30 min de isquemia ou $24 \mathrm{~h}$ antes da isquemia com a mesma dosagem $(280 \mu \mathrm{g} / \mathrm{kg})$. Os dados representam a média \pm EPM de 6 a 9 amostras. ${ }^{*} P<0,001$ em relação ao grupo sham; $\Phi P<0,001$ em relação ao grupo IR; $\alpha P<0,01$ IR E30` em relação ao grupo IR $0 V x ; \alpha P<0,05$ IR E24h em relação ao grupo IR OVx.
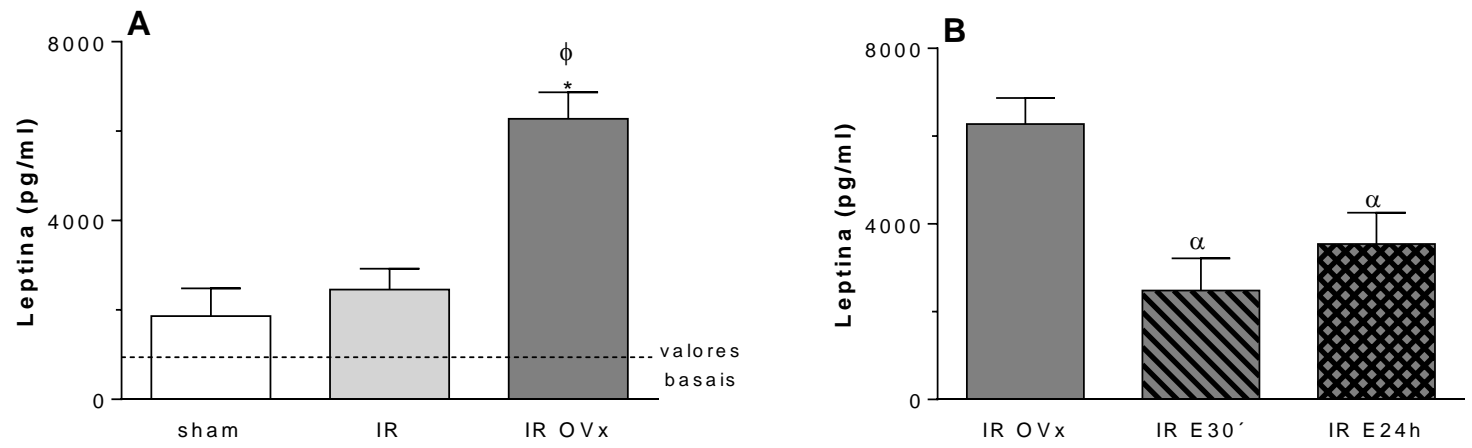


\subsection{Efeito da obstrução do fluxo do ducto linfático sobre a IR intestinal}

Uma vez que a IR intestinal gera uma inflamação sistêmica e que o sistema circulatório está intimamente ligado com o sistema linfático, resolvemos avaliar se a proteção das fêmeas aos efeitos deletérios ocasionados pela IR intestinal depende também da drenagem linfática. Pois dados gerados por Cavriani et al. (2005) anteriormente em machos revelaram grande importância da drenagem linfática para a manutenção da IR intestinal.

\subsubsection{Alterações ocasionadas no sítio inflamatório}

Nesta primeira parte dos estudos avaliamos os efeitos locais gerados pela IR intestinal em fêmeas com o ducto linfático intacto ou ligado e com ou sem ovários. Uma vez que estes estudos fossem positivos poderíamos então, inferir que o sistema linfático participa da resposta inflamatória diante da IR intestinal e, portanto, daríamos continuidade aos estudos seguintes.

- Permeabilidade vascular intestinal

Ao analisarmos a figura 31, podemos observamos que a obstrução do fluxo linfático de fêmeas com ovários intactos (grupo IR) aumentou o extravasamento do corante Azul de Evans na porção inicial do intestino delgado dos animais após a IR intestinal. Por outro lado, a interrupção do fluxo linfático em animais sem ovários (grupo IR OVx) reduziu o corante extravasado no tecido após a IR intestinal. Vale notar que comparando os grupos, observamos aumento do corante extravasado entre 0 grupo IR e IR OVx. O inverso ocorre ao analisarmos os mesmos grupos com o ducto linfático obstruído.

Figura 31 - Efeito da OVx sobre o extravasamento intestinal do corante azul de Evans em animais com o ducto linfático intacto ou ligado. As ratas OVx ou não foram submetidas à isquemia (45 min) e reperfusão intestinal ( 2 horas - IR intestinal). O corante $A E(20 \mathrm{mg} / \mathrm{kg})$ foi injetado $20 \mathrm{~min}$ antes do término da reperfusão. Os dados representam a média \pm EPM de 7-29 animais. ${ }^{*} P<0,001$ ducto intacto versus ducto ligado; $\phi P<0,001$ em relação ao grupo IR.

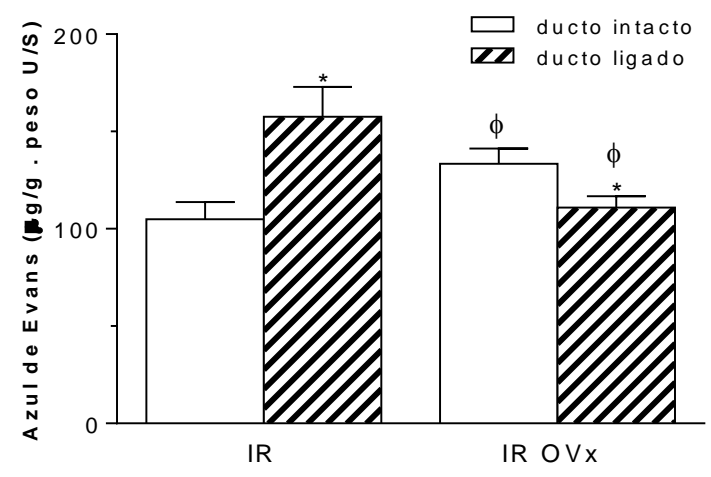


- Atividade da Enzima Mieloperoxidase (MPO) no intestino

Ao avaliarmos a atividade de MPO na parte inicial do intestino delgado dos animais com ducto linfático obstruído ou intacto observamos na figura 32, que a IR intestinal não alterou a MPO na região inicial do intestino delgado dos animais com o fluxo linfático intacto ou obstruído. Todavia, a remoção dos ovários (IR OVx) aumentou a atividade de MPO no intestino em relação ao grupo IR e IR OVx com ducto linfático ligado. Por outro lado, a obstrução do fluxo linfático nos animais do grupo IR OVx não alterou a atividade de MPO em relação ao grupo IR com ducto ligado.

Figura 32 - Efeito da OVx sobre a atividade de MPO em homogenatos de intestino de animais com o ducto linfático intacto ou ligado. As ratas OVx ou não foram submetidas à isquemia (45 min) e reperfusão intestinal (2 horas - IR intestinal). Os dados representam a média $\pm E P M$ de 5 a 9 amostras. ${ }^{*} P<0,001$ ducto intacto versus ducto ligado; ${ }^{\Phi} P<0,01$ em relação ao grupo IR.

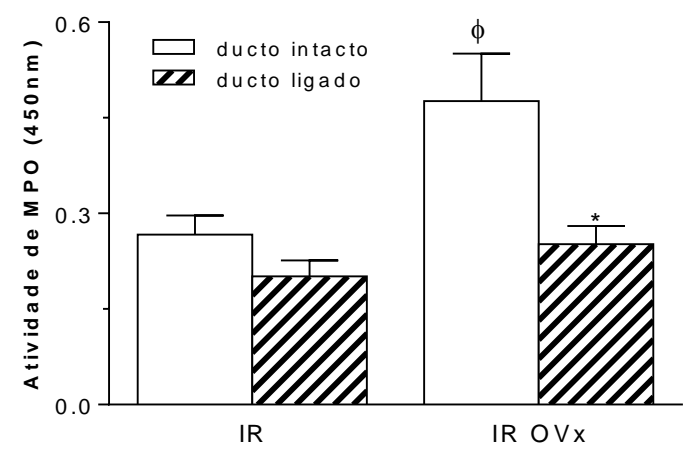

- Parâmetros da mucosa intestinal

Após identificarmos alterações na permeabilidade e celularidade no intestino, avaliamos também a integridade morfológica intestinal. Apesar de somente observarmos, inicialmente, a profundidade das criptas e a altura das vilosidades, nossos dados contidos na figura 33, painéis $A$ e $B$, estes parâmetros foram reduzidos nos grupos com obstrução do ducto linfático independetemente da presença dos hormônios sexuais femininos. 
Figura 33 - Efeito da OVx sobre a análise histológica do comprimento das vilosidades e da profundidade das criptas intestinais de fragmentos da porção inicial do intestino de fêmeas submetidas a IR intestinal com o ducto linfático intacto ou ligado. As ratas OVx ou não foram

submetidas à isquemia (45 min) e reperfusão intestinal (2 horas - IR intestinal). Os dados representam a média \pm EPM de 4 amostras. ${ }^{*} P<0,001$ ducto intacto versus ducto ligado; ${ }^{\Phi} P<0,01$ em relação ao grupo IR.
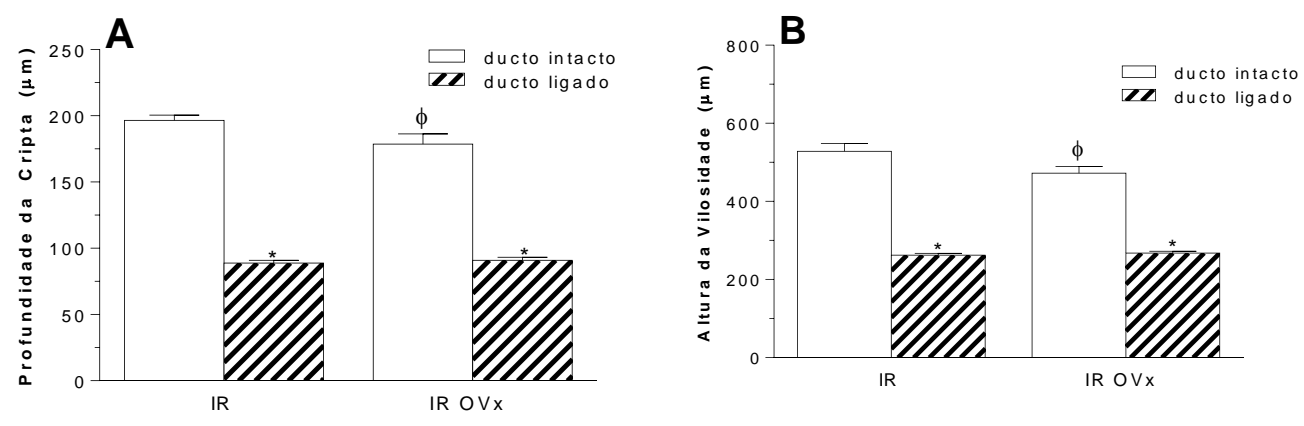

- Trânsito intestinal

Uma vez observadas alterações significativas na morfologia intestinal, investigamos se haviam alterações fisiológicas observando o fluxo do carvão ativado ao longo do intestino delgado. Os dados, representados na figura 34, indicam redução do trânsito intestinal em fêmeas com o ducto linfático obstruído após a IR intestinal em comparação com o ducto mantido intacto. Contudo, não observamos diferenças entre os animais sem ovários (IR OVx).

Figura 34 - Efeito da OVx sobre o trânsito intestinal de animais com o ducto linfático intacto ou ligado. As ratas $O V x$ ou não foram submetidas à isquemia $(45 \mathrm{~min})$ e reperfusão intestinal (2 horas - IR intestinal).Os dados representam a média \pm EPM de 5 a 9 amostras. ${ }^{*} P<0,001$ ducto intacto versus ducto ligado.

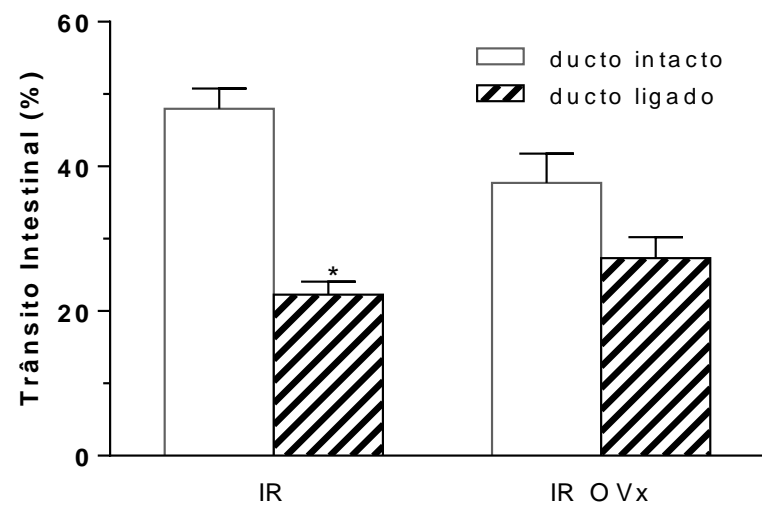




\subsubsection{Efeito da IR intestinal sobre a inflamação sistêmica}

Avaliamos também, parâmetros sistêmicos que sofreram alterações em decorrência da obstrução do ducto linfático torácico após a IR intestinal em fêmeas com ou sem ovários. Estes dados, permitiram avaliar a repercussão sistêmica da lesão local gerada e a influência da circulação linfática neste modelo experimental.

\section{- Número de leucócitos e plaquetas circulantes}

Inicialmente avaliamos a quantidade de leucócitos totais na circulação sanguínea em dois momentos: antes da IR intestinal (inicial) e após a IR intestinal (final). Estes dados nos permitem avaliar o recrutamento destas células diante do evento inflamatório. Os dados demonstrados na tabela 2 evidenciam um maior recrutamento de leucócitos após a IR intestinal sendo que, os animais com ovários intactos mobilizam mais células do que os animais com ovários removidos. E, a obstrução do ducto linfático aumentou cerca de $20 \%$ a mobilização celular independentemente da presença dos ovários.

Tabela 2. Efeito da OVx sobre a contagem total de leucócitos no sangue de ratas animais com o ducto linfático intacto ou ligado. As ratas OVx ou não foram submetidas à isquemia (45 min) e reperfusão intestinal (2 horas - IR intestinal).

$\begin{array}{r}\text { Inicial Final } \quad \begin{array}{r}\text { Índice de aumento do } \\ \text { número de leucócitos }(\%)\end{array} \\ \hline\end{array}$

\begin{tabular}{lccc}
\hline IR ducto intacto & $7461 \pm 505,5$ & $15654 \pm 1101^{*}$ & 109,81 \\
\hline IR ducto ligado & $8764 \pm 710,5$ & $19770 \pm 3097^{\star \alpha}$ & 125,58 \\
\hline IR OVx ducto intacto & $11405 \pm 582,4$ & $18845 \pm 1631^{*}$ & 65,23 \\
\hline IR OVx ducto ligado $^{*}$ & $12131 \pm 889,7$ & $22769 \pm 2174^{*}$ & 87,69 \\
\hline
\end{tabular}

Os dados representam a média \pm EPM de $10-24$ experimentos. ${ }^{*} P<0,05$ em relação ao valor inicial do experimento de cada grupo.

A análise diferencial das células circulantes não revelou diferenças significativas. Paralelamente, o número de plaquetas aumentou (figura 35) nos grupos submetidos à IR intestinal com o ducto linfático obstruído, independentemente dos HSF. 
Figura 35 - Efeito da OVx sobre a contagem de plaquetas de animais com o ducto linfático intacto ou ligado. As ratas OVx ou não foram submetidas à isquemia $(45 \mathrm{~min})$ e reperfusão intestinal (2 horas IR intestinal). Os dados representam a média \pm EPM de 10 a 24 amostras. ${ }^{*} P<0,05$ ducto intacto versus ducto ligado.

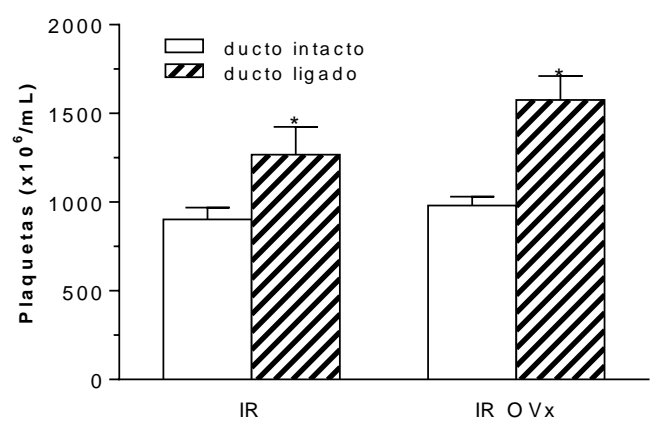

- Número de leucócitos presentes na medula óssea

Visto que o recrutamento celular depende da produção de células pela medula óssea, quantificamos as células totais presentes na medula óssea. Os dados apresentados na figura 36, mostram que somente as fêmeas OVx apresentaram diferença entre o ducto intacto e ligado após a IR intestinal. Esta diferença foi representada por uma drástica redução nas células no compartimento medular.

Figura 36 - Efeito da OVx sobre a contagem de leucócitos na medula óssea de animais com o ducto linfático intacto ou ligado. As ratas OVx ou não foram submetidas à isquemia (45 min) e reperfusão intestinal (2 horas - IR intestinal). Os dados representam a média \pm EPM de 10 a 24 amostras. ${ }^{*} P<0,05$ ducto intacto versus ducto ligado; ${ }^{\Phi} P<0,05$ IR $O V x$ versus IR.

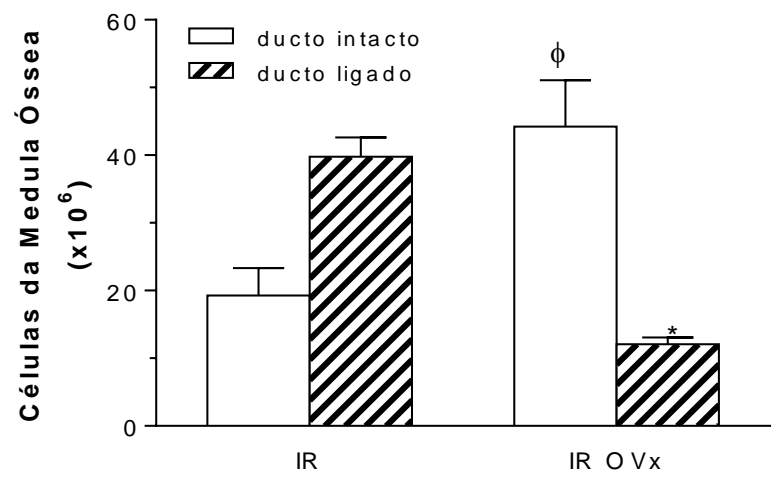

- Concentração sérica de mediadores inflamatórios

Em continuidade aos estudos, mensuramos a concentração sérica de alguns mediadores inflamatórios. A maioria dos mediadores analisados não encontramos diferenças estatisticamente diferentes, sendo elas: IL-10, MIP-1a, MIP-2, MCP-1, IP10, CINC-1, VEGF e RANTES. As únicas citocinas que encontramos diferenças estão representadas na figura 37 , sendo elas: leptina (painel A) e IL-1 $\beta$ (painel B). Os dados revelaram que fêmeas OVx com ducto ligado e submetidas a IR intestinal apresentam 
redução de leptina em comparação as fêmeas submetidas as mesmas circunstâncias, porém, com o ducto mantido intacto. Sendo que, observamos o oposto, quando as fêmeas OVx submetidas a IR intestinal com o ducto linfático intacto apresentam aumento de leptina em comparação ao grupo com ovários.

Já em relação a concentração de IL-1 $\beta$, painel B da Fig. 37, encontramos aumento desta citocina nas fêmeas $\mathrm{OVx}$ com o ducto linfático torácico ligado após a IR intestinal em comparação as fêmeas com ovários intactos submetidas à IR intestinal com ducto ligado.

Figura 37 - Efeito da OVx sobre a concentração sérica de leptina (painel A) e IL-1 $\beta$ (painel B) de animais com o ducto linfático intacto ou ligado. As ratas $\mathrm{OVx}$ ou não foram submetidas à isquemia (45 min) e reperfusão intestinal (2 horas - IR intestinal). Os dados representam a média \pm EPM de 10 a 24 amostras. ${ }^{*} P<0,05$ ducto intacto versus ducto ligado; ${ }^{\oplus} P<0,05 \mathrm{IR}$ OVx versus IR.
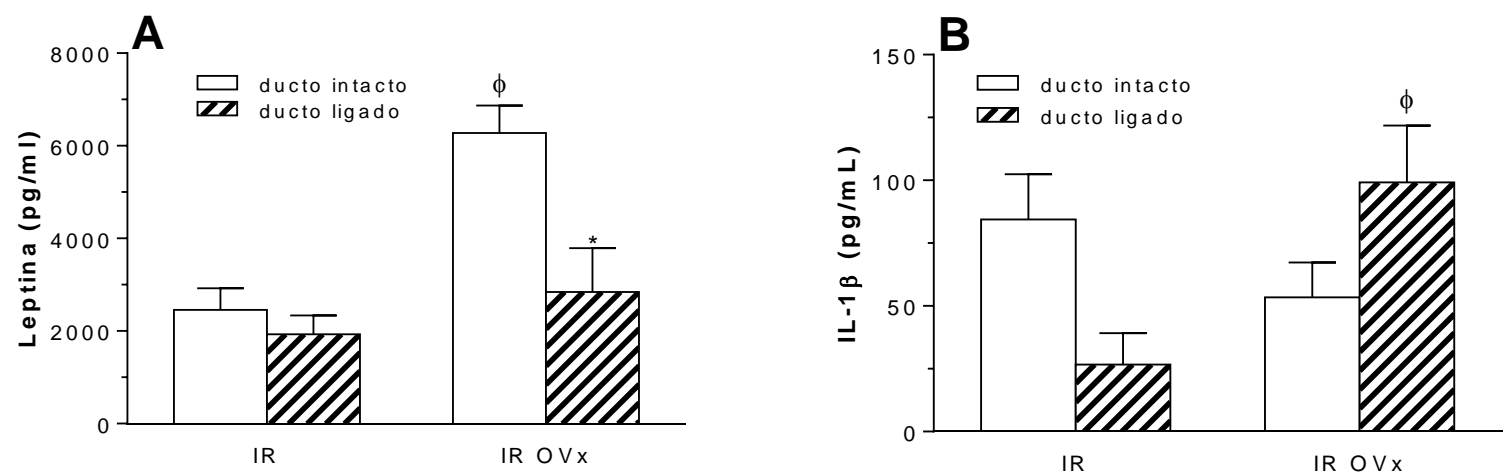

\subsubsection{Efeito da IR intestinal na composição da linfa}

- Volume e células presentes na linfa antes, durante e após a isquemia

Uma vez que a drenagem linfática pode exercer papel modulador sobre a inflamação local e em órgãos distantes, fomos investigar as alterações que a IR intestinal provoca sobre o fluxo linfático. Os dados acerca do volume de linfa coletado (Painel A - Fig. 38) indicam que o fluxo linfático de fêmeas sem ovários no período anterior a isquemia é maior se comparado com o grupo não OVx. É interessante notar que o fluxo linfático se reduz após a IR intestinal (LD) e o reestabelecimento da circulação não retoma o fluxo linfático (LR).

Em relação à quantidade de células presentes na linfa coletada (Painel B Fig. 38). Os dados indicam que durante o período de Isquemia há redução na quantidade de células totais na linfa coletada. Em relação ao período Reperfusão, o grupo não OVx não recuperou a quantidade inicial de células. Contudo, o grupo OVx 
aumentou a quantidade total de células tanto em relação ao grupo Isquemia quanto ao grupo não OVx.

Figura 38 - Efeito da IR intestinal sobre o volume de linfa coletado (painel A) e a quantidade de células presentes na linfa (painel $B$ ) em fêmeas com (não $O V x$ ) e sem ovários (OVx). Os dados apresentados são referentes ao momento antes do clampeamento da artéria mesentérica superior

(LC), durante o período de isquemia (LD) e durante o período de reperfusão (LR). Os dados representam a média \pm EPM de 5 animais. Painel $A:{ }^{*} P=0,0003$ grupo $O V x$ comparado ao não $O V x$;

${ }^{\Phi} P<0,0001$ comparado ao grupo LC. Painel $\mathrm{B}:{ }^{*} P=0,0058$ grupo $\mathrm{OVx}$ comparado ao não $\mathrm{OVx}$; ${ }^{\Phi} P=0,036$ grupo não $\mathrm{OV} x$ comparado período de LD ao LC; ${ }^{\Phi} P=0,002$ grupo OVx comparado período de LD e LC; ${ }^{a} P<0,0001$ período LR comparado ao LD.
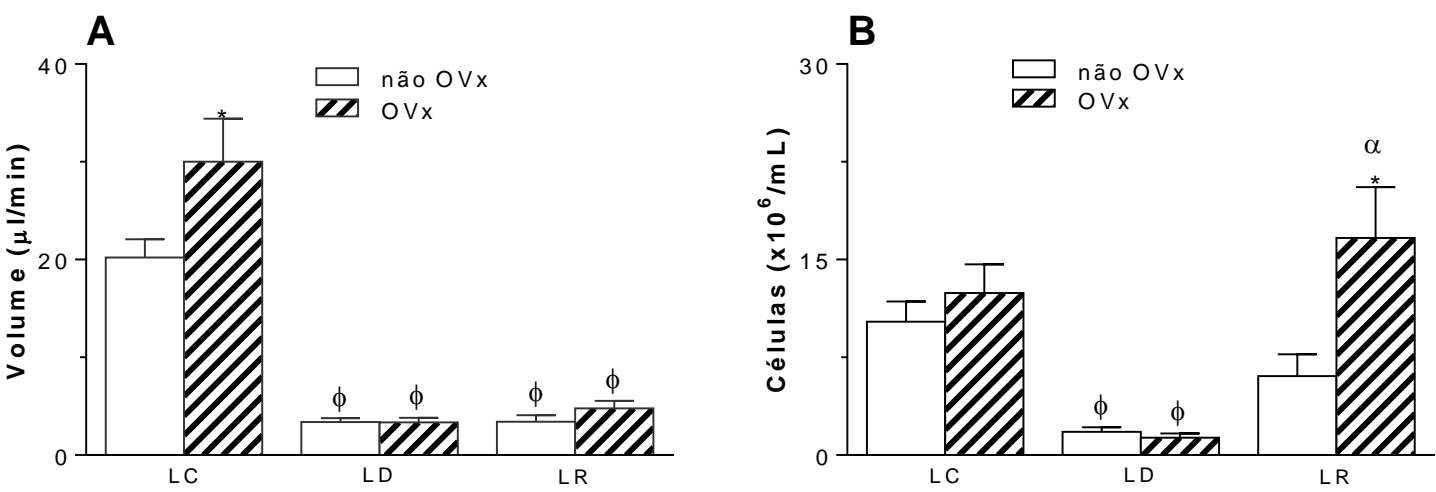

- Dosagem de mediadores inflamatórios presentes na linfa

Os dados acerca da concentração de mediadores inflamatórios antes da isquemia (LC, $15 \mathrm{~min}$ ) durante o período de isquemia intestinal (LD, $45 \mathrm{~min}$ ) e na reperfusão intestinal (LR, 2 h) estão apresentados na figura 39 e representam os valores de concentração de IL-10, IL-1 $1 \beta$ e IL-6.

A concentraçõe de IL-1 $1 \beta$ não diferiu entre os grupos estudados e entre as amostras de linfa (LC, LD, LR). Paralelamente, os dados de IL-6 mostraram aumento na concentração desta interleucina nas amostras LD e LR do grupo OVx quando comaradas com a amostra LC. Todavia, não observamos eese padrão no grupo nãoOVx e a comparação entre as amostras LR apontou aumento no grupo OVx em relação ao não-OVx. Já em relação a IL-10, observamos aumento somente no grupo OVx no período LR em relação a LC. 
Figura 39 - Efeito da IR intestinal sobre os níveis de IL-1 $\beta$ (Painel A), IL-6 (Painel B) e IL-10 (Painel C) na linfa de fêmeas com (não $O V x$ ) ou sem ovários $(O V x)$. A linfa foi avaliada em três períodos: Antes da indução da isquemia ( 20 min - LC), durante o período de oclusão da artéria mesentérica superior por $45 \mathrm{~min}$ (LD) e durante o período de reperfusão intestinal por $2 \mathrm{~h}$ (LR). Dados representam a média \pm EPM de 8 amostras de linfa. ${ }^{*} P<0,05$ grupo não $\mathrm{OVx}$ comparado ao grupo OVx, ${ }^{\alpha} P<0,05$ comparado ao grupo LC, ${ }^{\Phi} P<0,05$ comparado ao grupo LD.
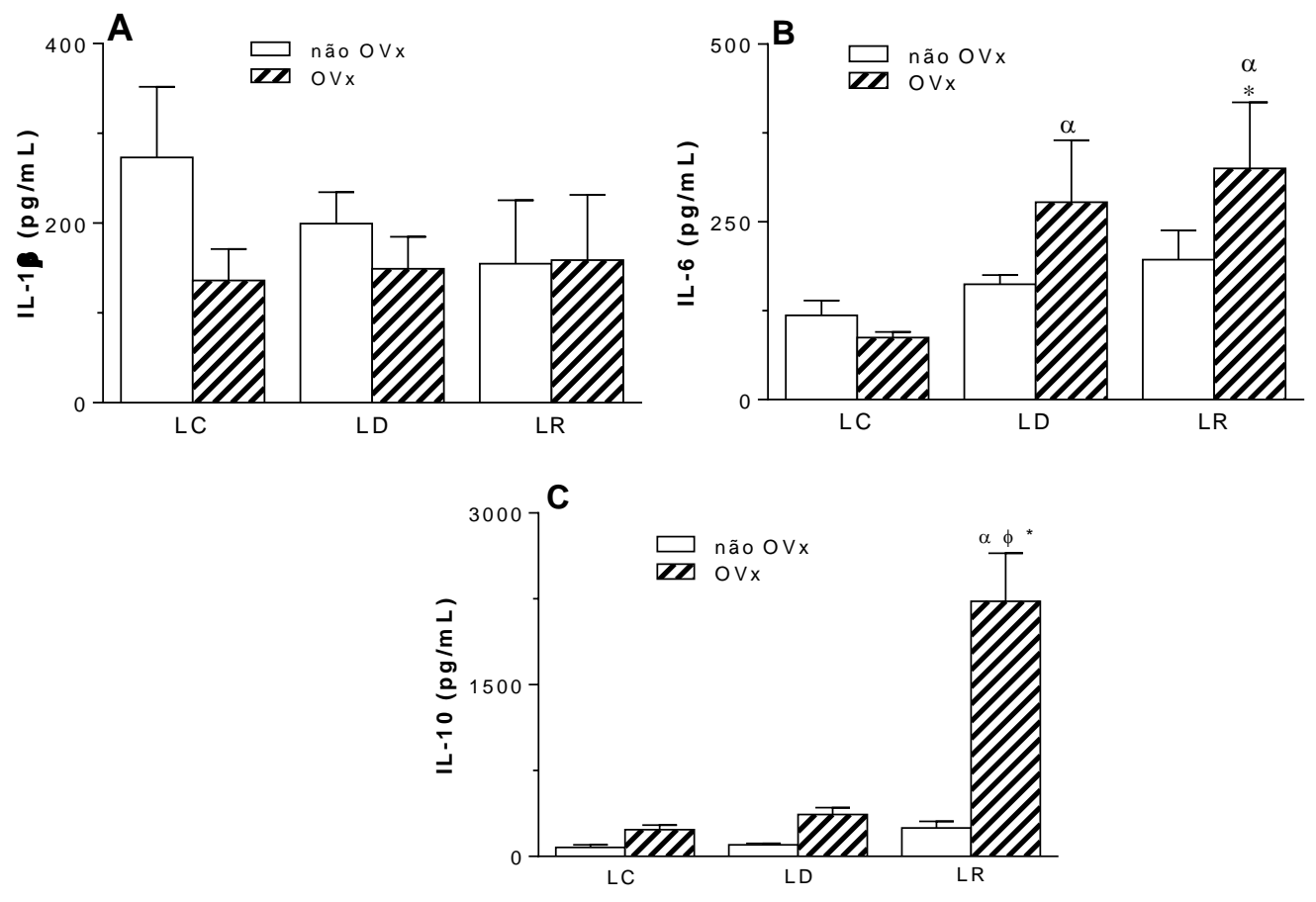

Além das citocinas acima apresentadas, neste estudo quantificamos a concentração de TNF- $\alpha$ e VEGF na linfa nos três períodos já referidos. Os resultados obtidos devem ser vistos com cautela uma vez que detectamos forte variabilidade tanto para os níveis de TNF- $\alpha$ como para o VEGF. Por causa disso, não nos foi possível estabelecer análise consistente. Apesar do mencionado, e a título de exercício considerando os dados gerados podemos supor que fêmeas geraram TNFa o qual foi detectado na linfa antes (controle) e durante o período de isquemia intestinal, mas não no período de reperfusão intestinal e que o VEGF foi detectado em todos os períodos investigados.

\section{- Caracterização das células presentes na linfa}

Uma vez obtida informações acerca do volume da linfa durante a IR intestinal, o teor de algumas citocinas e o número total de leucócitos presentes decidimos investigar mais qualitativamente as células na linfa. Estes estudos foram conduzidos em colaboração com o Doutorando Cristiano Rossato Laboratório de Interações 
Neuroimunes do Departamento de Imunologia, sob supervisão do Prof. Dr. Jean Pierre Schatzmann Peron. Na medida em que estudos sobre atividade funcional das células não foram realizados, os dados aqui apresentados são essencialmente descritivos.

A figura 40 representa os tipos celulares encontrados nas amostras de LC e LR dos grupos OVx e não OVx. Os dados gerados, indicaram redução das células MHC $\mathrm{II}^{+}$(painel A) nos animais OVx no período controle e esta redução se manteve durante a reperfusão. Em relação as fêmeas não $\mathrm{OVx}$, as células $\mathrm{MHC} \mathrm{II}^{+}$reduziram-se durante a reperfusão. Já em relação as células CD11 b/c+ (painel B) não encontramos alterações significativas, nem em comparação ao período controle e de reperfusão nem em relação à presença ou ausência dos hormônios sexuais femininos. O mesmo

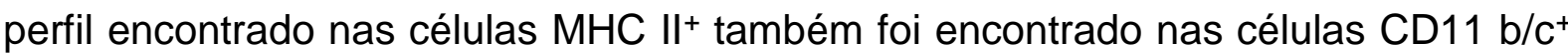
MHC II+ (painel C).

Figura 40 - Determinação por citometria de fluxo de células presentes na linfa que expressam

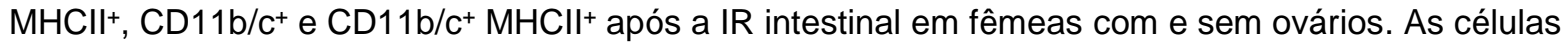
foram avaliadas em dois períodos: Antes da isquemia intestinal (20 min - Controle) e durante o período de reperfusão intestinal ( $2 \mathrm{~h}$ Reperfusão). Os dados representam a média \pm EPM de 9-12 amostras de células. ${ }^{*} P<0,05$ grupo $\mathrm{OVx}$ comparado não $\mathrm{OVx}$, ${ }^{a} P<0,05$ comparado ao grupo Controle.
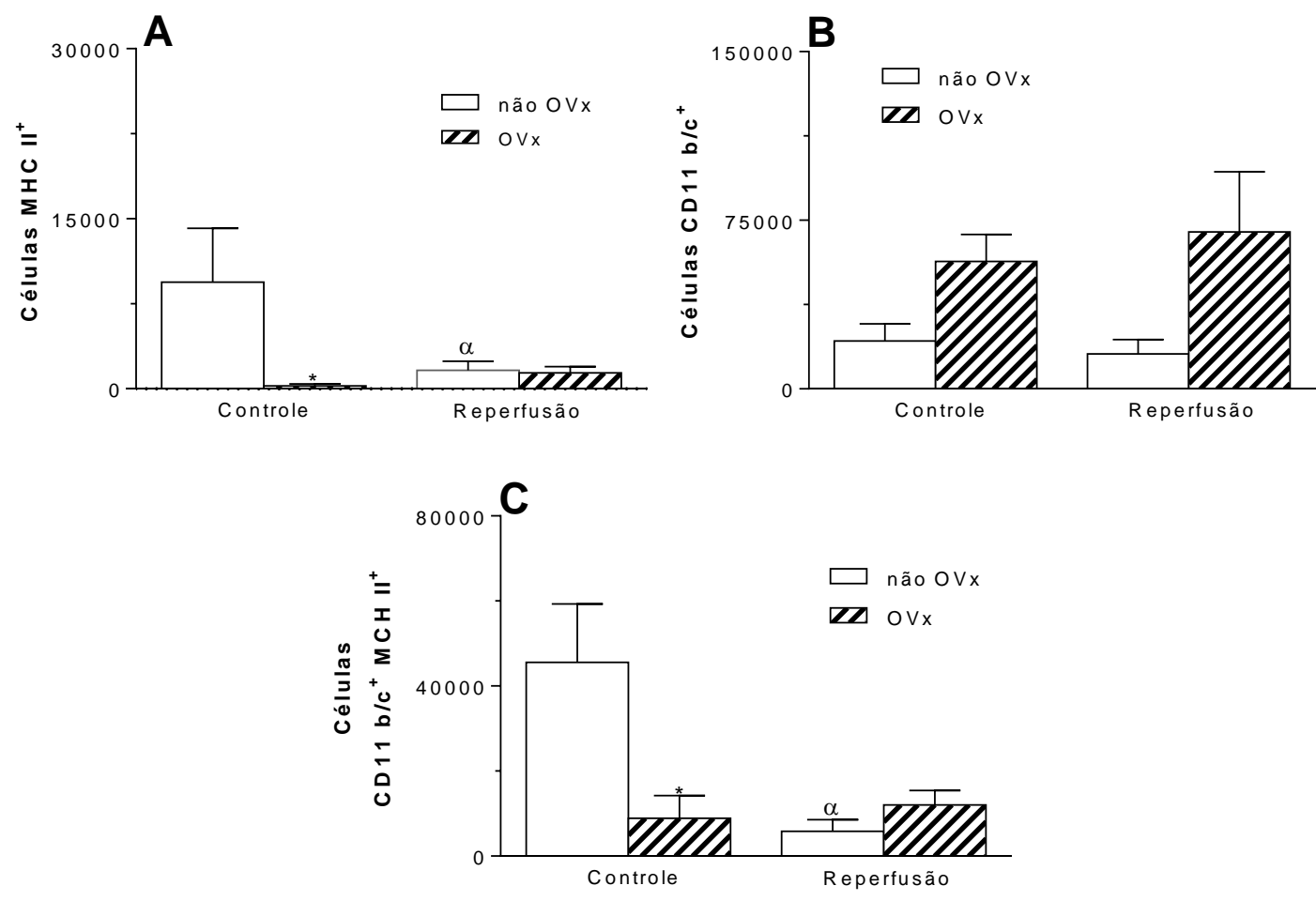
Dando continuidade aos estudos de identificação da população das células presentes na linfa dos animais submetidos à IR intestinal, observamos que fêmeas OVx apresentaram elevação de células CD5+ em relação às não OVx no período reperfusão (Figura 41, painel A). Diferentemente do observado para as células CD5 ${ }^{+}$, nossos dados não indicaram mudanças na expressão de células $\mathrm{CD}^{+} \mathrm{MHC} \mathrm{II}^{+}$(Figura 41, painel B) nem entre os grupos (não OVx e OVx) bem como dentro dos períodos de análise (LC e LR).

Figura 41 - Determinação por citometria de fluxo de células presentes na linfa que expressam $\mathrm{CD}^{+} \mathrm{e}$ $\mathrm{CD5}^{+} \mathrm{MHC} \mathrm{II+}$ após a IR intestinal em fêmeas com e sem ovários. As células foram avaliadas em dois períodos: Antes da isquemia intestinal (20 min - Controle) e durante o período de reperfusão intestinal (2 h Reperfusão). Os dados representam a média \pm EPM de 9-12 amostras de células. ${ }^{*} P<0,05$ grupo OVx comparado não OVx.
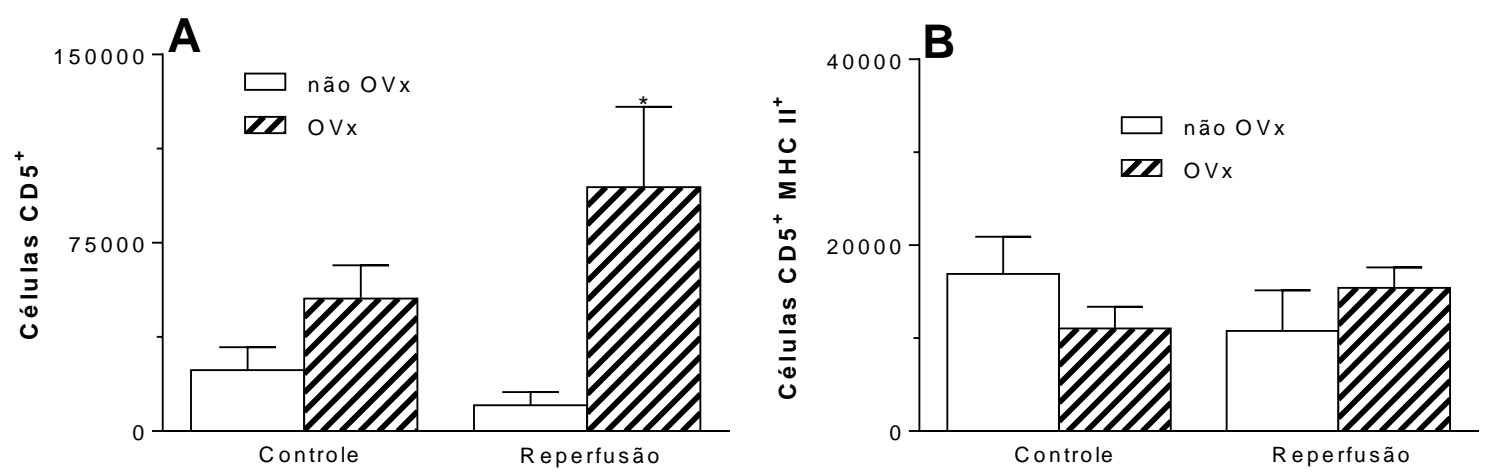

Ainda no contexto da caracterização das células presentes na linfa, foi avaliado se granulócitos poderiam ser drenados para a linfa na vigência da IR intestinal. Estas células recrutadas para um foco inflamatório apresentam expressão de Ly6G+. Nossos dados (Figura 42, painel A) mostram que a expressão desse marcador na linfa não diferiu entre não OVx e OVx no tempo referente ao controle, isto é, antes da indução da IR intestinal. De interesse foi observar que na linfa de reperfusão dos animais $O V x$, o número de células que expressam Ly6G+ aumentou de forma significativa em relação aos não OVx.

Em contraste ao observado para as células $\mathrm{Ly}_{6 \mathrm{G}}{ }^{+}$na linfa obtida de fêmeas durante a reperfusão intestinal, a quantidade de células $\mathrm{Ly} 6 \mathrm{C}^{+}$na linfa controle das OVx se reduziu em comparação a não OVx e no período determinado como reperfusão, observamos que há redução independentemente da presença de hormônios (figura 42, painel B). Nossos estudos também revelaram a existência de uma subpopulação de células aptas a expressaram ambos marcadores, constituindo 
assim uma eventual população mista cuja caracterização nossos dados não permitem identificar. Todavia é interessante considerar que esta população aparentemente é constitutiva, visto estar presente na linfa controle de ambos os grupos (não OVx e $\mathrm{OVx}$ ), porém durante a reperfusão intestinal observamos que somente fêmeas não OVx apresentaram redução dessas células.

Figura 42 - Determinação por citometria de fluxo de células presentes na linfa que expressam Ly6G+, Ly6C+ e Ly6G+ Ly6C+ após a IR intestinal em fêmeas com e sem ovários. As células foram avaliadas em dois períodos: Antes da isquemia intestinal (20 min - Controle) e durante o período de reperfusão intestinal (2 h Reperfusão). Os dados representam a média \pm EPM de 9-12 amostras de células.

${ }^{*} P<0,05$ grupo OVx comparado não OVx, ${ }^{a} P<0,05$ comparado ao grupo Controle.
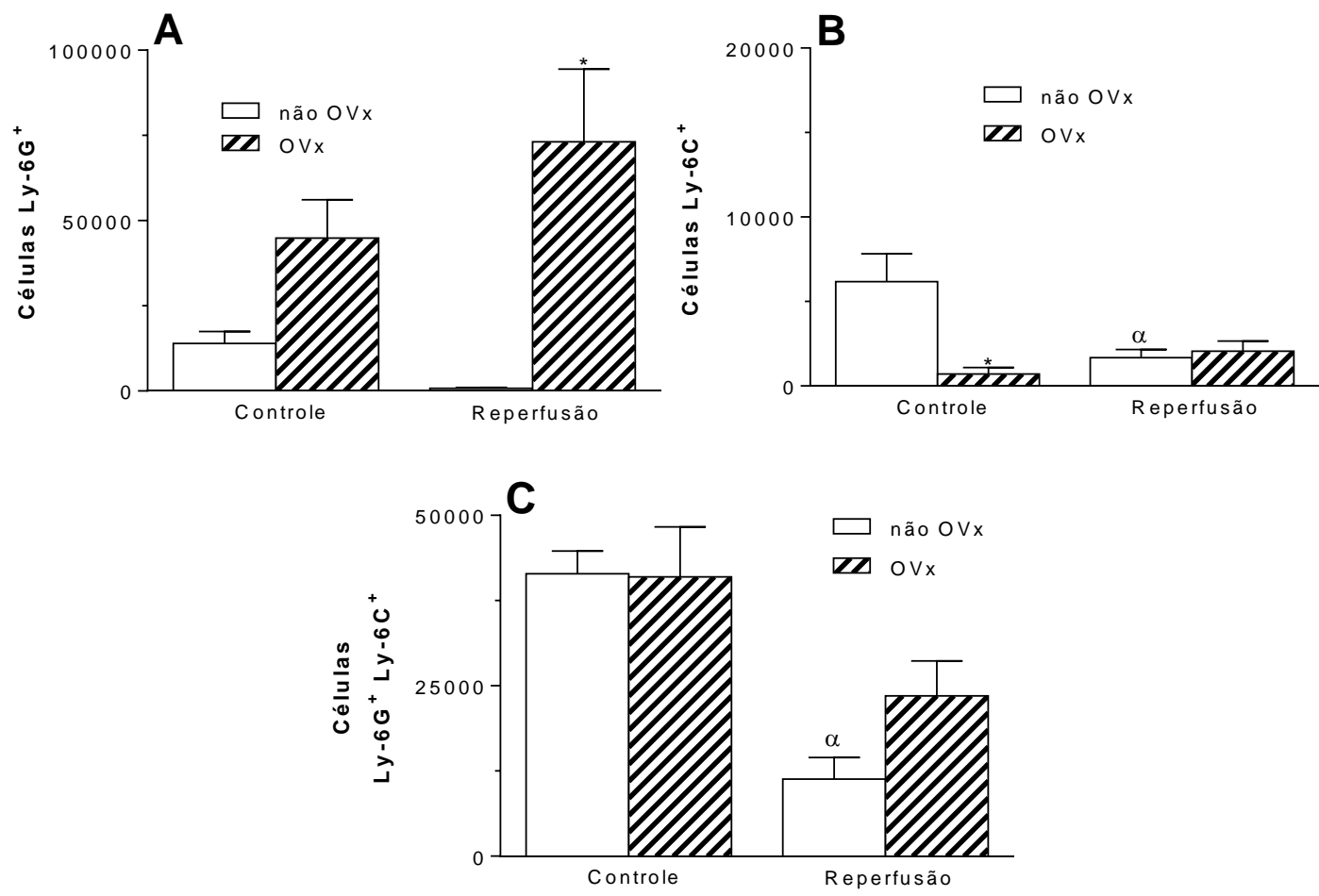

Para finalizar esta fase do estudo de caracterização das células contidas na linfa, avaliamos a presença de células $\mathrm{CD}^{+}$e $\mathrm{CD} 4^{+} \mathrm{CD} 8^{+}$. A figura 43 (painel A) representa os dados obtidos e indica que linfócitos $T$ auxiliares $\left(C D 4^{+}\right)$estão presentes na linfa de fêmeas não OVx e OVx em ambos os períodos analisados (controle e reperfusão) sem diferenças significativas. Com respeito aos linfócitos $C D 4^{+} / \mathrm{CD}^{+}$ (Figura 43, painel B) os dados mostraram que, na linfa controle das fêmeas OVx se reduziram em comparação a da não OVx e no período determinado como reperfusão, observamos que há redução independentemente da presença de hormônios. 
Figura 43 - Determinação por citometria de fluxo de células presentes na linfa que expressam $\mathrm{CD}^{+} \mathrm{e}$ $\mathrm{CD}^{+}{ }^{+} \mathrm{CD} 8^{+}$após a IR intestinal em fêmeas com e sem ovários. As células foram avaliadas em dois períodos: Antes da isquemia intestinal (20 min - Controle) e durante o período de reperfusão intestinal (2 h Reperfusão). Os dados representam a média \pm EPM de 9-12 amostras de células. ${ }^{*} P<0,05$ grupo OVx comparado não $O V x,{ }^{a} P<0,05$ comparado ao grupo Controle.
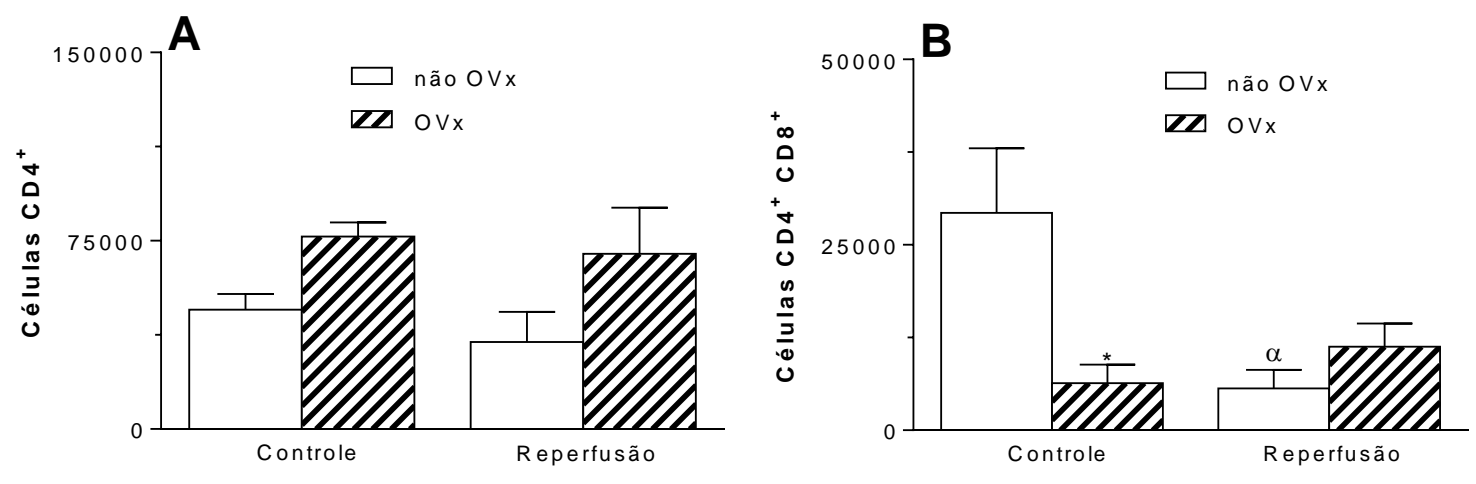

69 


\section{DISCUSSÃO}

Os estudos realizados neste trabalho foram direcionados no sentido de investigar as repercussões da IR intestinal desencadeada em ratas. Neste sentido avaliamos o efeito modulador do estradiol na inflamação local, sistêmica e efeito da obstrução do ducto linfático torácico. Consideramos também compartimentalizar a discussão nos contextos estudados (local, sistêmico e linfático) com o intuito de obter melhor fluidez na interpretação dos resultados gerados. É importante ressaltar que o fio condutor do presente estudo foi avaliar e compreender o papel modulador dos hormônios sexuais femininos, notadamente do estradiol, nas consequências inflamatórias locais e sistêmicas geradas pela IR intestinal.

Além disto, comparamos dados gerados em fêmeas com ovários preservados com aqueles obtidos em fêmeas com 7 dias de ovariectomia (OVx). Os estudos sobre o papel do estradiol ficaram circunscritos aos seus potenciais efeitos terapêuticos ou preventivos. Portanto, o papel do estradiol foi avaliado tratando grupos de animais OVx com o esteroide 30 minutos após a obstrução da artéria mesentérica superior, isto é, após o desencadeamento da isquemia intestinal (grupo IR E30') ou em animais tratados $24 \mathrm{~h}$ antes do desencadeamento da isquemia intestinal (grupo IR E24h).

A percepção de que o estradiol poderia ter relevância neste estudo se reforça considerando evidências experimentais indicando efeito protetor do estradiol, em modelo de IR intestinal, comparando ratas em proestro com machos. Nestes estudos os autores avaliaram a permeabilidade vascular, o recrutamento e atividade de neutrófilos (DEITCH et al., 2007). Vale ressaltar que dados anteriores do nosso laboratório indicaram que ratos machos e fêmeas OVx quando tratados com estradiol apresentaram redução do aumento de permeabilidade vascular, da atividade de MPO, e da expressão de moléculas de adesão no pulmão e da produção de IL-10 e IL-1 $\beta$ (BREITHAUPT-FALOPPA et al., 2013; FANTOZZI, 2013). Ainda, estudos de outros grupos mostraram que o intestino de fêmeas OVx tratadas com estradiol apresenta redução da lesão intestinal e da expressão de iNOS também em modelo de IR intestinal (XIAO et al., 2004).

\subsection{Efeito do estradiol na inflamação local causada pela IR intestinal}

Neste segmento avaliamos a inflamação local e apresentamos dados acerca da atividade de MPO, permeabilidade vascular intestinal (extravasamento do corante 
azul de Evans) e permeabilidade macromolecular intestinal. Também discutimos os dados sobre a motilidade e integridade da mucosa intestinal, além daqueles sobre o conteúdo do fluido intestinal presente na cavidade peritoneal dos animais, volume, quantidade total e diferencial de células e algumas citocinas envolvidas com a inflamação. Finalizando este primeiro segmento avaliamos o perfil gênico inflamatório e da sinalização induzida pelo estradiol no mesentério.

A isquemia intestinal foi realizada obstruindo o fluxo da artéria mesentérica superior por meio de sua oclusão por 45 min. Após este período, o fluxo da artéria foi reestabelecido e a perfusão intestinal reiniciada. Decorridas $2 \mathrm{~h}$ de reperfusão intestinal os animais foram submetidos à eutanásia e os experimentos conduzidos. Os dados obtidos neste estudo indicaram que animais OVx e submetidos a IR intestinal desenvolveram aumento do extravasamento do corante azul de Evans na porção inicial do intestino delgado e da concentração sérica de Dextran-FITC após sua administração intraduodenal. Estes resultados permitiram concluir que a IR intestinal aumentou a permeabilidade do epitélio intestinal e do endotélio vascular intestinal e possivelmente causou algum grau de lesão no intestino.

Considerando estes resultados e tendo em mente que a IR intestinal causou aumento no intestino da atividade da enzima MPO, então evidencia-se que a IR intestinal causa uma resposta inflamatória local potencialmente lesiva, cuja magnitude pode estar associada à presença de estradiol. Neste sentido, é interessante que em estudos anteriores mostramos que fêmeas com ovários preservados não desenvolvem um significativo aumento de permeabilidade vascular e nem de recrutamento de neutrófilos para o pulmão após serem submetidas à IR intestinal (FANTOZZI, 2013). A comparação destes dados obtidos em fêmeas com ovários preservados ou OVx após submetidas a IR intestinal permitem concluir que 0 hormônio sexual exerce importante papel modulador das repercussões locais após a IR intestinal. Estes resultados são de interesse, pois o intestino é considerado o motor da inflamação em modelos de trauma seguido de choque hemorrágico (DEITCH et al., 1994).

Visto que nestas condições o intestino produz mediadores inflamatórios, então alguns aspectos da resposta inflamatória sistêmica e em órgãos distantes podem ser decorrentes dos efeitos locais da IR intestinal. Com relação ao efeito modulador dos hormônios sexuais, nossos dados estão de acordo com os encontrados na literatura 
os quais dizem respeito à ausência de inflamação em fêmeas com os ovários preservados. De fato, estudos conduzidos por Homma et al., (2005) mostraram que o intestino das fêmeas é mais resistente ao trauma seguido de choque hemorrágico em comparação com o observado no intestino de machos. Segundo os autores, uma das possibilidades para essa proteção é que o fluxo sanguíneo intestinal das fêmeas durante o choque hemorrágico é mais bem preservado. De interesse e como mencionado Deitch et al. (2008), mostraram que fêmeas em proestro têm o intestino mais resistente ao desenvolvimento de lesões causadas pela IR intestinal em comparação com o observado em machos.

Também ganham destaque estudos clínicos (WIJNEN et al., 2002) e experimentais (CHANG et al., 2005; HOMMA et al., 2005; QIN et al., 2011) os quais mostraram aumento de permeabilidade da mucosa intestinal após períodos de baixa oxigenação em modelo de IR intestinal. Assim, nossos estudos sobre a permeabilidade ao Dextran poderiam indicar que a IR intestinal causou quebra da integridade da barreira intestinal, evento que pode facilitar não apenas a inflamação local, mas também concorrer para o desencadeamento de translocação bacteriana e em condições mais graves o desencadeamento de septicemia bem como para a atividade funcional e de motilidade do intestino após a IR intestinal. Vale lembrar que apesar do mencionado, existem estudos sugerindo que em humanos a translocação bacteriana não representa evento essencial para o desenvolvimento da septicemia (VAISHNAVI et al., 2013). No conjunto estes sugerem que a IR intestinal em fêmeas OVx comprometeu, no local onde foi desencadeada, a integridade da mucosa intestinal fragilizando os efeitos protetores da barreira intestinal.

De maneira a compreender a importância do estradiol na integridade intestinal, tratamos as fêmeas OVx com estradiol previamente (IR E24h) ou terapeuticamente (IR E30'), isto é, 30 minutos após a indução da isquemia. A percepção deste último protocolo experimental é de que a isquemia possa disparar mecanismos que medeiem a resposta inflamatória. Nossos dados mostraram que o tratamento prévio dos animais com estradiol (IR E24h) preveniu o aumento do extravasamento do corante azul de Evans, o aumento sérico de Dextran-FITC e da atividade de MPO. Por outro lado, o tratamento terapêutico dos animais (IR E30') somente preveniu o recrutamento de neutrófilos na porção inicial do intestino delgado. Estes resultados podem indicar que existe uma modulação da atividade funcional de neutrófilos na IR intestinal que é 
mediada pelo estradiol no qual a expressão de moléculas de adesão, pode ser relevante. À luz desses achados podemos inferir, ainda que hipoteticamente, uma importância clínica em nossos dados uma vez que, mulheres com baixa quantidade de hormônios sexuais femininos são mais susceptíveis a um quadro inflamatório local e sistêmico após um evento de IR intestinal e sendo assim a administração de estradiol poderia influênciar na melhora das repercussões inflamatórias.

Considerando os dados sobre o recrutamento de neutrófilos para o intestino, permeabilidade vascular e da mucosa intestinal numa tentativa de estabelecer correlação com o efeito protetor do estradiol sugerimos que a redução da produção de citocinas como CINC-1, IL-6, TNF- $\alpha$ e MIP-2 como observada neste estudo e a menor expressão de ICAM-1 e iNOS em modelo de trauma seguido de choque hemorrágico (HOMMA et al., 2005; YU et al., 2006) poderiam representar um potencial mecanismo acionado pelo estradiol. Embora não tenhamos avaliado diretamente a relação entre o papel destas citocinas e quimiocinas sobre os eventos inflamatórios locais, sugerimos que sua redução mediada pelo estradiol poderia diminuir/prevenir a adesão de leucócitos ao endotélio, notadamente de neutrófilos e assim controlar a lesão da mucosa intestinal. No geral nossos resultados são interessantes pois reforçam a percepção de que fêmeas são mais protegidas das repercussões locais da IR intestinal. Além disso, o intestino visto como o órgão central no desencadeamento das lesões em órgãos distantes, aparentemente medeia essas ações por mecanismos que envolvem o recrutamento celular e o aumento de permeabilidade vascular e macromolecular intestinal. Realmente os animais do grupo OVx que apresentam inflamação local observada nos experimentos realizados neste estudo, também apresentaram alterações sistêmicas e pulmonares mais exuberantes do que os animais com ovários intactos, em experimentos realizados no meu mestrado (FANTOZZI, 2013).

Dando continuidade aos estudos dos efeitos locais causados pela IR intestinal, avaliamos o trânsito intestinal dos grupos de animais estudados. A idéia deste estudo surgiu a partir dos dados obtidos de estudos em parceria utilizando o modelo de IR intestinal em ratos machos. Esses dados revelaram que a IR intestinal altera diferentes subpopulações de neurônios no plexo mioentérico intestinal acompanhado de alterações morfológicas (PALOMBIT et al., 2013). Assim, considerando que estas alterações poderiam afetar a motilidade intestinal. Nossos dados indicaram que a IR 
intestinal aumentou o trânsito intestinal em animais com ovários preservados assim como em animais OVx tratados com estradiol $24 \mathrm{~h}$ antes de serem submetidos a IR intestinal, portanto preventivamente. Todavia, a remoção dos ovários e o tratamento dos animais OVx com estradiol 30 min após a indução da isquemia (tratamento terapêutico) não modificaram o perfil do trânsito intestinal. Esses dados podem indicar que concentrações consideradas fisiológicas de estradiol interferem com o trânsito e, portanto, com a motilidade intestinal e possivelmente de forma independente da IR intestinal.

Outro aspecto interessante é que a remoção dos ovários aparentemente previne o aumento de motilidade intestinal. Uma questão que também pode ser levantada refere-se ao período de tratamento dos animais com estradiol. É razoável supor que suas ações sobre a geração de mediadores que atuam no controle do peristaltismo intestinal possam ser uma alternativa para explicar tais efeitos. Nesse contexto, o estudo do sistema mioentérico de fêmeas OVx e a análise do perfil de receptores purinérgicos no intestino podem ser de interesse para elucidar a relação entre o estradiol e a atividade funcional do intestino em condições de IR intestinal. É interessante notar que estes dados podem estar em linha com os obtidos por Homma et al. (2005), que mostraram que o intestino de fêmeas é mais resistente à lesão e ao desencadeamento de inflamação do que o de machos, em modelo de trauma seguido de choque hemorrágico. Ainda, diversos estudos sustentam o envolvimento do NO com a inflamação causada pela IR intestinal, assim como o papel do estradiol na geração de NO. Portanto é possível estabelecer correlação do NO nas repercussões intestinais e pulmonares da IR intestinal (WARD et al., 2000; XIAO et al., 2004; BREITHAUPT-FALOPPA et al., 2013; BREITHAUPT-FALOPPA et al., 2014).

Uma vez que identificamos alterações na motilidade do intestino dos animais, decidimos avaliar em que medida a IR intestinal poderia interferir com alguns parâmetros de mucosa intestinal. Para tanto, mensuramos o comprimento das vilosidades e a profundidade das criptas em amostras do segmento inicial do jejuno dos animais após a IR intestinal. Estes dados são de interesse na medida em que as criptas podem exercer papel regenerador das vilosidades e isto poderia ser representado por um aumento na profundidade das criptas. Estas informações nos pareceram importantes visto a potencial correlação entre a integridade da mucosa intestinal, seu rompimento causado pela IR intestinal e o possível desenvolvimento de 
translocação bacterina. Nossos dados revelaram aumento na profundidade da cripta no grupo IR em comparação ao grupo Sham. Notamos também redução na altura das vilosidades no grupo IR OVx comparado ao grupo IR e seu aumento quando administramos estradiol terapeuticamente (IR E30'). Contudo, o tratamento prévio com estradiol (IR E24h) reduziu tanto o comprimento das vilosidades como a profundidade das criptas. Esses dados indicam que as alterações na mucosa intestinal devem ser mediadas pelo estradiol em concentrações mais altas. Apesar do mencionado podemos sugerir que um tempo maior de reperfusão intestinal poderia ser necessário para que a cripta pudesse recuperar suas vilosidades intestinais.

É interessante notar que nossos dados referentes às vilosidades e às criptas estão em linha com os obtidos por Sukhotnik et al. (2016) que investigaram os mesmos parâmetros no intestino de ratos após a IR intestinal. Estes autores investigaram a mucosa intestinal 48 horas após a obstrução da artéria mesentérica por 30 min enquanto que nossos estudos foram conduzidos $2 \mathrm{~h}$ após o início da reperfusão intestinal. Em estudos onde o período de reperfusão foi de 24 h, Sukhotnik et al. (2007) detectaram redução na profundidade da cripta a qual foi regenerada pelo tratamento dos animais com leptina. Assim, poderíamos sugerir que a atividade da cripta como elemento de regeneração das vilosidades teria sua recuperação, neste modelo, em até $48 \mathrm{~h}$, muito embora a recuperação da vilosidade não ocorrer em tempo similar.

A seguir consideramos que o intestino sob o estresse da isquemia e reperfusão poderia ter sua homeostasia alterada. Assim, estudos foram conduzidos isolando o intestino dos animais durante a IR intestinal em uma embalagem plástica e ao final do experimento, coletamos o líquido exsudado pelo intestino durante todo o período de IR intestinal. Os nossos dados revelaram redução significativa do volume de fluido intestinal gerado nos animais submetidos a IR intestinal em comparação aos animais do grupo não exposto a condições similares, mas sem desencadeamento da IR intestinal. Apesar de inesperados, estes resultados podem ser de interesse porque, eventualmente, a IR intestinal tenderia a induzir maior acúmulo de líquido nos tecidos o que poderia contribuir para um menor fluxo de líquido para a região peritoneal. Vale lembrar que nossos dados sobre a alteração do volume do líquido exsudado causado pela IR intestinal foi mediada pelo estradiol. 
$\mathrm{Na}$ medida em que observamos maior tráfego de neutrófilos para o intestino decidimos avaliar o número de leucócitos (total e diferencial) presentes no líquido intestinal exsudado coletado. Os resultados indicaram redução na quantidade de células totais e de granulócitos após a IR intestinal em fêmeas com ovários preservados e nas OVx. Além disto, os tratamentos dos animais com estradiol não foram efetivos em modificar este parâmetro, sugerindo que o componente celular do exsudado neste modelo não é mediado pelo estradiol e possivelmente este evento não corresponde a uma resposta de magnitude importante. Retomando a discussão sobre o exsudado, existem pelo menos duas possibilidades para o acúmulo de líquido peritoneal, as quais são classificadas em exsudativas ou transudativas. A primeira (exsudativa) se refere, em geral, ao acúmulo de líquido peritoneal decorrente do excesso de fluxo do compartimento vascular para a cavidade peritoneal o qual é geralmente proveniente de um processo inflamatório ou neoplásico. A segunda (transudativa) seria decorrente da transudação de leitos capilares e da circulação linfática esplâncnica ou hepática, resultante do aumento da pressão venosa (MCDERMOTT et al., 1964; TARN \& LAPWORTH, 2010).

Neste estudo podemos entender, visto a instalação de um evento inflamatório local, que o fluido peritoneal pode ter se originado por um fenômeno de exsudação. Estudos feitos por Emr et al. (2014) em porcos evidenciaram que a retirada de líquido peritoneal após evento séptico reduz a inflamação local, sistêmica e pulmonar. Portanto, apesar dos nossos achados não terem evidenciado mudanças significativas no número de leucócitos e havermos encontrado redução do líquido exsudado após a IR intestinal, entendemos que o estudo deste líquido é relevante para a compreensão da inflamação sistêmica causada pela IR intestinal visto que eventos locais no intestino podem liberar mediadores, células e proteínas no líquido intestinal que uma vez absorvidos pelo sistema circulatório ou drenados pelo sistema linfático são carregados para outros órgãos.

Em resumo, ao analisarmos nossos dados observamos que a IR intestinal reduziu a quantidade de granulócitos no fluido intestinal e que esta redução é um evento independente da ação dos hormônios sexuais femininos. Estes resultados podem sugerir que a redução do número de células no fluido intestinal decorra de sua permanência no intestino em função dos efeitos da inflamação local gerada pela IR intestinal. Ainda, o aumento de atividade de MPO no intestino de fêmeas OVx 
submetidas à IR intestinal fortalece a percepção de que neutrófilos recrutados para o intestino permaneceram paralisados neste compartimento.

Uma vez analisada a quantidade de exsudado intestinal e das células presentes, determinamos a concentração de algumas citocinas presentes no fluido intestinal. A IR intestinal não induziu aumento significativo de IL-10 intestinal em ambos os grupos de animais, isto é, com ou sem ovários. Todavia, animais OVX revelaram maior tendência de geração desta citocina e quando tratados com estradiol 30 min após o início da isquemia tiveram aumento significativo na concentração de IL10. Considerando o papel anti-inflamatório da IL-10, estes dados abrem a possibilidade de o efeito protetor do estradiol nestes animais poder ser resultante de um aumento geração de IL-10 no intestino. Esta sugestão pode ser de interesse para compreender o mecanismo protetor do estradiol pelo aumento local de IL-10 que, uma vez absorvido pelo sistema circulatório e/ou linfático pode modular os efeitos sistêmicos da IR intestinal. Em relação à CINC-1, nossos dados indicaram sua redução após a indução da $I R$ intestinal nos animais com ovários intactos em comparação ao grupo de animais submetidos aos mesmos procedimentos, mas sem indução da IR intestinal. Neste último grupo observamos aumento da CINC-1, porém não nos ativemos a investigar as razões que possam justificar a alta concentração intestinal nestes animais da quimiocina.

Foi interessante observar que após a OVx a IR intestinal causou redução adicional de CINC-1 e que esta redução não foi sensível ao tratamento dos animais com estradiol. Assim, é possível considerar que outros hormônios ovarianos possam modular a geração de CINC-1 na vigência da IR intestinal. Eventos que se associam a lesão tecidual levam ao aumento da síntese desta quimiocinas pelo fígado causando elevação de seus níveis séricos e a mobilização de neutrófilos para o sangue (CAMPBELL et al., 2003). A IR intestinal determina inflamação em órgãos distantes e possivelmente interfira com a atividade funcional hepática, todavia nossos resultados não permitem estabelecer associação a tais eventos intestinal.

Ainda, no contexto do estudo da alteração de parâmetros locais causada pela IR intestinal, avaliamos os perfis gênicos, inflamatório e de estradiol no mesentério das fêmeas a fim de obter informações sobre alguns mecanismos orquestradores da inflamação gerada pela IR intestinal nos OVx. Neste contexto, nossos resultados indicaram que fêmeas com ovários preservados, apesar de serem menos propensas 
a desenvolver a resposta inflamatória após a IR intestinal, expressam, com algum grau, genes moduladores da resposta inflamatória no mesentério. Por outro lado, as fêmeas OVx expressaram os mesmos genes numa magnitude muito maior $(4,14$ vezes). Especificamente, o gene Ccr4 é um receptor de quimiocinas que tais como MCP-1, MIP-1 e RANTES, as quais medeiam o recrutamento de leucócitos. Portanto, a remoção ou não dos ovários é uma condição que pode modular distintos mecanismos reguladores da inflamação após IR intestinal, justificando possivelmente, a pequena parcela de genes que são identificados como expressos em ambos os grupos, por isso, a maior intensidade nas fêmeas OVx em relação as fêmeas não OVx no que tange as repercussões da IR intestinal. Nossos estudos também avaliaram o pefil de expressão gênica do Mif. Este fator é um inibidor de recrutamento de macrófagos que exerce importante papel na função imune e, também se contrapõe aos efeitos anti-inflamatórios do corticoide em humanos. Assim, em nosso estudo, a observação de redução da expressão gênica do Mif em animais OVx tratados com estradiol (IR E24h) poderia representar uma ação anti-inflamatória indireta sobre a corticosterona dos animais, representando assim um mecanismo anti-inflamatório.

Em outra análise avaliamos o RGD1561905, o qual representa o gene codificador de componente do sistema complemento 5 (C5), um fator do complemento ligado à resposta imune e que pode estar envolvido com as lesões intestinais causadas pela IR intestinal. Nossos achados indicando aumento de expressão (upregulation) deste gene nas fêmeas OVx tratadas com estradiol (IR E24h) reforçam a percepção de que a presença do estradiol determina distinções no curso da resposta inflamatória após a IR intestinal.

Também foi avaliado a expressão de Ccl12, uma quimiocina com efeitos próinflamatórios, notadamente, sobre recrutamento de leucócitos para um sito inflamatório e que a progesterona, em alguns modelos de inflamação alérgica, por exemplo, revelou ter efeito anti-inflamatório (DE OLIVEIRA et al., 2007). Efeitos protetores da progesterona também sobre parâmetros cardiovasculares também foram observados em modelo de trauma seguido de choque hemorrágico (KUEBLER et al., 2003). Nossos dados revelaram redução da expressão de Ccl12 em animais OVx tratados previamente com estradiol (IR E24h) quanto comparado com o grupo IR OVx. Acreditamos que o estradiol, nas condições em que foi administrado para as fêmeas OVx neste estudo pode ter gerado um sinal para a indução da fase de 
proestro, fase esta que é seguida pelo estro. O estro, pela sua curta fase temporal em ratas pode dar início ao aumento da concentração de progesterona e nesse sentido justificaríamos o aumento da expressão de genes associados aos receptores de progesterona.

Tomados em conjunto os dados discutidos neste segmento reforçam a percepção de que o intestino e o mesentério são compartimentos afetados pela IR intestinal e que o estradiol pode exercer efeito modulador em algumas das alterações funcionais desses compartimentos. À luz desses achados e considerando o intestino como motor da inflamação nossos estudos foram focalizados sobre o compartimento sistêmico.

\subsection{Efeito da IR intestinal sobre a inflamação sistêmica}

Neste segmento pudemos observar as repercussões da IR intestinal como um todo, e não apenas no contexto dos eventos locais envolvidos. A premissa é que ao avaliarmos a inflamação gerada no local da lesão e suas consequências sistêmicas haveria maior possibilidade de entender a complexidade do estresse gerado pela IR intestinal.

$\mathrm{Na}$ medida que está bem estabelecido que eventos isquêmicos intestinais seguidos de sua reperfusão causam inflamação sistêmica e lesão em órgãos distantes do local onde ocorreu, decidimos investigar alguns eventos que pudessem oferecer algum grau de entendimento de como a inflamação local poderia ser disseminada. Para tanto optamos por quantificar os leucócitos circulantes e os presentes na medula óssea. Além disso, consideramos que a IR intestinal poderia interferir com a atividade funcional dos leucócitos, notadamente na sua capacidade de migrar. A idéia foi quantificar a migração in vitro de neutrófilos coletados dos animais submetidos à IR intestinal e neste sentido avaliamos a migração espontânea de neutrófilos obtidos dos animais estudados. Estes estudos surgiram da premissa de que no evento inflamatório observado durante a IR intestinal ocorre a liberação de fatores quimiotáxicos que mobilizam células inflamatórias, notadamente os neutrófilos (XU et al., 2009). Como mencionado anteriormente, nossos achados mostraram que no intestino dos animais há aumento da atividade de MPO após a IR intestinal.

Considerando que existe conexão entre o recrutamento de neutrófilos para um sitio inflamatório e aumento da expressão de moléculas de adesão e que este 
aumento pode depender das ações de mediadores inflamatórios liberados,

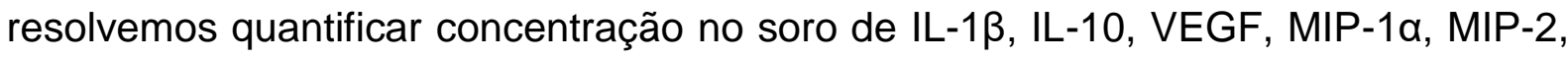
MCP-1, CINC-1, RANTES, IP-10 e leptina.

Iniciamos estes estudos sistêmicos quantificando os leucócitos presentes no sangue dos animais antes e após a indução da IR intestinal. Numa análise mais geral os nossos dados permitiram inferir a existência de um maior aporte de leucócitos ao compartimento circulatório após a IR intestinal, maior aporte este com destaque para o grupo de animais IR intestinal do grupo OVx. Contudo, notamos nos animais com ovários intactos aumento predominante de linfócitos e de monócitos enquanto nos animais do grupo OVx a IR intestinal se relacionou com aumento, essencialmente de granulócitos, possivelmente de neutrófilos. A considerar o efeito protetor do estradiol no curso da resposta inflamatória o aumento do número de neutrófilos circulantes nos animais OVx podemos sugerir maior sensibilidade de fêmeas às repercussões da IR intestinal. De fato, nossos dados revelaram que fêmeas OVx tratadas com estradiol terapeuticamente (IR E30`) apresentaram redução no número de granulócitos circulantes após a IR intestinal. Em contraste, fêmeas hormonalmente ativas podem ser consideradas mais resistentes aos efeitos da IR intestinal. Tais observações estão em linha com estudos realizados por Deitch et al. (2007) o qual avaliou mais de 4 mil pacientes em situações de trauma ou choque hemorrágico concluindo que, as mulheres hormonalmente ativas sobrevivem mais que os homens nestas condições.

Nossos dados também mostraram que nos animais OVx houve aumento do número de linfócitos e de plaquetas e que este aumento precedeu a indução da IR intestinal. Estes dados se analisados no contexto da importância da formação de complexo de plaquetas com neutrófilos podem ter significado adicional para a diapedese de neutrófilos (THOMAS \& STOREY, 2015) e eventualmente justificar a maior tendência de fêmeas OVx desenvolverem mais inflamação após a IR intestinal. É interessante notar que a formação de complexos de neutrófilos com plaquetas no contexto da inflamação foi investigada por Page e Pitchford (2013) mostrando que a formação do complexo auxilia o recrutamento de neutrófilos para o sítio inflamatório, pois as plaquetas aumentam a adesão de neutrófilos ao endotélio.

Uma vez observada a mudança no perfil de leucócitos circulantes em decorrência da IR intestinal fomos investigar o aporte medular dos leucócitos de maneira a estabelecer uma possível correlação com os achados no soro. De forma 
geral nossos dados tomados mostraram maior número de células na medula óssea dos animais IR com os ovários preservados. Os resultados também revelaram uma possível ativação medular nos animais submetidos à ovariectomia. Além disso, nossos resultados sugerem que a falta de hormônios sexuais circulantes ou sua redução a valores abaixo dos fisiológicos pode interferir com a atividade funcional da medula óssea elevando o seu número de células o qual não foi corrigido pelos protocolos de tratamentos propostos com estradiol.

Como mencionado, uma das hipóteses gerados foi a de que a IR intestinal poderia alterar a atividade funcional de neutrófilos. Uma forma de investigar esses potenciais efeitos, de maneira indireta, foi analisar a capacidade de migração de neutrófilos obtidos de animais submetidos a IR intestinal. Vale lembrar que a inflamação causada agudamente pela IR intestinal, seja ela local ou em órgãos distantes como ocorre no pulmão, é mediada essencialmente por neutrófilos. Nossos dados indicaram que neutrófilos circulantes obtidos de animais OVx submetidos à IR intestinal migraram espontaneamente com mais intensidade do que aqueles obtidos de fêmeas com ovários intactos e, também de neutrófilos oriundos dos animais não submetidos à IR intestinal, reforçando assim a percepção de que a IR intestinal medeia a atividade de neutrófilos circulantes. É possível, portanto que tais neutrófilos circulantes por estarem mais ativos ao serem recrutados para o local e para órgãos distantes do local da IR concorram para a induzir uma nova onda de geração de mediadores envolvidos com a inflamação. Nestas condições a inflamação não somente se dissemina como pode adquirir maior gravidade. De fato, estes achados podem justificar o aumento da atividade de MPO no intestino e reforçam que neutrófilos ativos após a IR intestinal podem ser mobilizados e recrutados para um local distante contribuindo assim para as consequências inflamatórias da IR intestinal.

De importância é considerar que o tratamento dos animais OVx com estradiol, tanto previamente como terapeuticamente, preveniu a migração espontânea dos neutrófilos, fato que pode sugerir uma vez mais sua ação sobre a ativação dessas células in vivo e observada in vitro. Estudos conduzidos por Doucet et al. (2010), em modelo de trauma seguido de choque hemorrágico partindo da premissa de que fêmeas hormonalmente ativas são mais protegidas, avaliaram o papel dos receptores de estradiol (ER) no efeito protetor desse hormônio. De acordo com estes autores os ER do subtipo $\beta$ estão envolvidos no controle e na mediaçuma menor ativação de 
neutrófilos. Estes dados reforçam a relevância do estradiol na modulação do recrutamento/atividade de neutrófilos na IR intestinal, todavia nossos dados não permitem indicar qual sub-tipo de receptor medeia este evento no nosso modelo.

Ainda no contexto das repercussões sistêmicas desencadeadas pela IR intestinal, um aspecto importante foi avaliar a possível interação de mediadores quimiotáxicos gerados com o estradiol. Nossos estudos não identificaram a origem (fonte) de geração dos mediadores presentes no soro, mas os diversos fatores, citocinas e quimiocinas detectados sugerem o potencial lesivo sistêmico da IR intestinal. Nossos dados mostraram aumento significativo causado pela IR intestinal no grupo de animais OVx na maioria dos mediadores analisados (IL-10, MIP-1a, MIP2, MCP-1, CINC-1, IP-10 e leptina). Estes dados se revestem de importância na medida em que diversos estudos mostraram o envolvimento destes mediadores na inflamação após a IR intestinal (ATTUWAYBI et al., 2004; CAVRIANI et al., 2004; GROTZ et al., 1999; KNUDSEN, et al., 2011; LI et al., 2010; LIU et al., 2014; POPE et al., 2010; SOUZA et al., 2001, 2003, 2004; YAO et al., 1995). Por outro lado, nossos estudos não identificaram diferenças nos valores séricos de VEGF, RANTES e IL-1 $\beta$ desses animais. Seja como for nossos dados permitiram concluir que a IR intestinal desencadeou inflamação sistêmica nos animais OVx. Considerando isto, investigamos o efeito do tratamento dos animais com estradiol e pudemos observar o estradiol foi eficaz em diminuir a concentração de mediadores de forma não uniforme, ou seja, alguns mediadores como IP-10 e leptina diminuíram a sua concentração em decorrência a ambos os protocolos de tratamento com estradiol (IR E30' e IR E24h).

Outros, como MIP-1a, MIP-2, MCP-1 e CINC-1 reduziram apenas com o protocolo de tratamento com estradiol $24 \mathrm{~h}$ antes da indução da isquemia. Em relação ao protocolo de tratamento com estradiol 30 minutos após o início da isquemia, nossos dados indicaram aumento de RANTES. Por fim, algumas citocinas não foram moduladas por nenhum dos protocolos de tratamento com estradiol, foram elas: IL10 , IL-1 $\beta$ e VEGF. Podemos considerar, portanto, que o tratamento preventivo com o estradiol parece exercer melhor efeito protetor com relação ao terapêutico.

A IR intestinal gera um amplo espectro de produção de mediadores os quais ao exercerem um complexo conjunto de interações medeiam a resposta local e em órgãos distantes. Neste sentido, nos pareceu interessante o estradiol exercer efeitos protetores ao ser administrado terapeuticamente e preventivamente. Alem disso, os 
dados indicaram que cada protocolo de tratamento dos animais com estradiol apresentou grau variável de seletividade para modular os mediadores. A análise destes resultados usando os distintos protocolos de tratamento com estradiol pode sugerir que as repercussões da IR intestinal dependam de mecanismos de indução que são temporalmente acionados. Vale lembrar que estudos realizados por outros autores confirmaram o papel protetor do estradiol na produção de mediadores na inflamação. Estudos de Frazier-Jessen e Kovacs (1995) mostraram que macrófagos obtidos do peritônio de ratos modulam a expressão de MCP-1 e adicionalmente, o tratamento com estradiol em mulheres após a pós-menopausa reduziu a concentração de MCP-1 no plasma (KOH et al., 2001). Ainda, Cox et al. (2015) mostraram que o estradiol em doses baixas $(25 \mu \mathrm{g}$ e $2,5 \mu \mathrm{g})$ foi efetivo em reduzir a concentração no plasma de IL-6, MCP-1 e CINC-1 em modelo de lesão da medula espinhal. Podemos, portanto, com estes dados, indicar que o estradiol pode ter efeito protetor na inflamação sistêmica causada pela IR intestinal. A repercussão desta modulação pode estar relacionada com os efeitos protetores do estradiol em órgãos distante do local da inflamação.

É interessante notar que nos estudos em que mostramos o papel do estradiol no controle da inflamação pulmonar causada pela IR intestinal (BREITHAUPTFALOPPA et al., 2013; FANTOZZI et al., 2018) não permitiram revelar se os efeitos do estradiol nos animais foram diretos no pulmão ou indiretos modulando a resposta inflamatória local ou sistêmica. Paralelamente é possível considerar também que o momento da administração do estradiol (IR E30' ou IR E24h) pode ser decisivo para modificar o curso da geração de mediadores de forma diferente. Tomados em conjunto sugerimos que o estradiol exerce efeito protetor parcial. Estes resultados também permitem inferir uma potencial importância clínica de nossos estudos e nesse sentido alertam para a relevância de se considerar os níveis circulantes de estradiol e sua administração no decorrer de um evento isquêmico com o objetivo de minimizar os efeitos deletérios da falha no suprimento sanguíneo local.

Avaliando o painel de resultados como um todo, podemos sugerir que fêmeas IR OVx desenvolvem uma inflamação local e sistêmica de maior magnitude do que fêmeas IR mantidas com ovários preservados. Estes dados se alinham aos obtidos anteriormente em relação à inflamação pulmonar após a IR intestinal (FANTOZZI, 2013). No presente estudo a inflamação local mostrou ser controlada diferentemente 
quando há os hormônios sexuais femininos ou não. Além disso, também pudemos observar uma vez mais o efeito protetor do estradiol administrado $24 \mathrm{~h}$ antes da indução da IR intestinal, reduzindo assim a inflamação ocasionada nos animais OVx. Contudo, o tratamento de estradiol na vigência da IR intestinal (IR E30') aparenta ser menos efetivo em reduzir os efeitos deletérios da IR intestinal. É possível que eventos desencadeados por 30 minutos de isquemia intestinal deflagrem efeitos inflamatórios os quais não são revertidos pelo tratamento posterior com estradiol.

Dados anteriores obtidos em nosso laboratório (CAVRIANI et al., 2005; CAVRIANI et al., 2007, BREITHAUPT-FALOPPA et al., 2009; BREITHAUPTFALOPPA et al., 2012) e de outros grupos (MAGNOTTI et al., 1998; MAGNOTTI et al., 1999; ADAMS et al., 2001; DEITCH et al., 2001; HE et al., 2012; YANG et al., 2012) revelaram o papel do sistema linfático como modulador da inflamação pulmonar e sistêmica em modelo de IR intestinal e em modelo de trauma seguido choque hemorrágico. De forma geral, a obstrução do fluxo linfático se relaciona com um efeito protetor do quadro inflamatório instituído pela IR intestinal. Por esta razão decidimos, no último bloco de estudo avaliar o envolvimento do sistema linfático no nosso modelo de estudo.

\subsection{Efeito da obstrução do ducto linfático sobre a IR intestinal}

Finalizando nosso estudo, neste segmento incluímos experimentos para compreender o papel do sistema linfático em fêmeas submetidas a IR intestinal. Como já mencionado, dados anteriores conduzidos em machos mostraram melhora do quadro inflamatório quando obstruímos o fluxo do ducto linfático (CAVRIANI et al., 2005; CAVRIANI et al., 2007). Para isso, o ducto linfático superior foi obstruído e avaliamos a atividade de MPO e permeabilidade vascular na porção inicial do intestino dos animais. Também foram conduzidos experimentos com o ducto linfático canulado para coletarmos amostras de linfa e posterior quantificação de seu volume, da quantidade de células e da concentração de citocinas. Desta forma consideramos que as repercussões locais da IR intestinal poderiam ser identificadas determinando-se esses parâmetros e, portanto, teríamos uma estimativa do papel do sistema de drenagem na IR intestinal e sua interação com os hormônios sexuais femininos.

Os dados anteriores gerados pelo laboratório acerca da participação da drenagem linfática no controle das repercussões pulmonares, sistêmicas e intestinais 
da IR intestinal, indicaram que a obstrução do fluxo linfático torácico atenua as consequências da IR intestinal em ratos machos (CAVRIANI et al., 2005). Baseados nestas informações, consideramos investigar se eventos similares poderiam ser observados em fêmeas. Diferentemente do esperado, observamos que animais com ovários intactos os quais não desenvolvem inflamação exuberante, ao terem a obstrução do fluxo do ducto linfático passaram a exibir um quadro inflamatório significativo. De fato, detectamos aumento do extravasamento do corante azul de Evans na porção inicial do intestino delgado desses animais. Além disso, observamos redução da inflamação nos animais OVx, submetidos a IR intestinal (IR OVx) quando foram submetidos à obstrução do fluxo do ducto linfático. Esta redução inflamatória foi caracterizada pela diminuição do extravasamento do corante azul de Evans e, também pela atividade da enzima MPO no intestino.

Apesar de encontrarmos evidências que mostram redução na inflamação local após a IR intestinal ao obstruirmos o ducto linfático de fêmeas OVx, não encontramos diferenças na funcionalidade e morfologia intestinal. Isto é, ambos os parâmetros citados se reduziram em fêmeas OVx e não OVx, apontando para uma piora local destes animais ao se obstruir o ducto linfático. Quando consideramos avaliar a inflamação sistêmica nesses animais, observamos semelhança no recrutamento celular entre as fêmeas com ovários preservados e aquelas OVx. De fato, nestas condições não houve diferença na elevação na quantidade de leucócitos totais circulantes e da medula óssea nem do número de plaquetas quando comparado com os dados gerados nos animais com ducto linfático intacto, portanto com fluxo linfático funcional o que nos sugeriu uma exacerbação da inflamação sistêmica causada pela IR intestinal. Estes resultados se contrapõem aos obtidos em machos nos quais a obstrução do fluxo é responsável pela atenuação da inflamação causada pela IR intestinal. No presente estudo apesar de encontrarmos maior número de células totais nas amostras de linfa, não fomos capazes de identificar se a elevação decorre de aumento de algum tipo celular específico, o que nos levou a considerar que é uma exacerbação mediada pelos diversos tipos celulares analisados (linfócitos, monócitos e granulócitos).

Avaliando os efeitos sistêmicos da IR intestinal nesses animais quantificando os mediadores nos animais com ducto intacto e nos animais em que o fluxo linfático foi obstruído ducto linfático. A percepção para a condução destes estudos foi 
considerar que a linfa como via transportadora de mediadores poderia interferir com o curso da inflamação sistêmica. Nossos dados mostraram que a concentração de leptina reduziu em fêmeas $\mathrm{OVx}$ com o ducto obstruído em comparação com as fêmeas mantidas com ducto intacto. É interessante observar que apesar de ser um marcador comum para obesidade a leptina também participa da resposta imune, inclusive da ativação quimiotáxica de neutrófilos e do retardamento de sua apoptose (FANTUZZI, 2005; BRUNO et al., 2005). Por isso, em processos inflamatórios é comum encontrar níveis séricos elevados de leptina (CAVA \& MATARESE, 2004). Sugerindo então, que a obstrução do ducto linfático pode estar reduzindo a inflamação encontrada nestes animais quando estão com o ducto linfático intacto. Porém, encontramos aumento na concentração de IL-1 $\beta$ no soro dos animais OVx com ducto ligado ao comparar com o grupo de animais com ovários sobre as mesmas condições (IR intestinal + obstrução do ducto linfático torácico). É possível que esta interleucina não sofra influência da circulação linfática.

Muito embora os dados do presente estudo não tenham permitido indicar como se processa a interação do estradiol com o fluxo do ducto linfático na vigência da IR intestinal, nossos resultados reforçam a importância da drenagem linfática em fêmeas e sua contribuição para a homeostasia durante a IR intestinal. Apesar do mencionado neste segmento conduzimos análises com objetivo de elucidar a importância do sistema linfático no contexto da qualidade da linfa. Para tanto coletamos a linfa pelo ducto linfático torácico e analisamos o seu volume, o perfil de células e de citocinas. Estes estudos se ajustam ao já mencionado objetivo de correlacionar os eventos inflamatórios com o funcionamento do sistema linfático neste modelo. $O$ que detectamos foi que o volume recuperado de linfa antes da indução da isquemia (considerado com um controle) é maior nos animais OVx do que nos animais com ovários intactos.

Ainda durante o período de isquemia (45 min) e na reperfusão intestinal (2 h), observamos uma redução drástica do volume de linfa recuperado. Vale ressaltar que tal redução foi similar nos grupos de animais OVx e não OVx. Embora nossos estudos não tenham avaliado os potenciais mecanismos que possam justificar a redução no volume de linfa nesses períodos, é possível inferir que a queda do fluxo durante o período de isquemia pode ser causada pela redução do fluxo sanguíneo para o mesentério em decorrência da obstrução da artéria mesentérica superior e 
consequente desvio para outras regiões. Além disso, poderíamos considerar que algum mecanismo contrarregulador tenha sido acionado a fim evitar perdas adicionais de nutrientes presentes e aprisionados pela isquemia regional. Estudos conduzidos por Yang et al. (2012) revelaram que em modelo de isquemia de 45 min seguido de reperfusão intestinal de $6 \mathrm{~h}$, ocorreu uma disfunção do fluxo da linfa mesentérica caracterizada pela redução do fluxo linfático. Assim, nossos dados parecem se ajustar aos observados por esses autores. É notável que a expectativa inicial foi a de que durante a reperfusão intestinal o fluxo linfático seria retomado aos valores do grupo controle ou até poderiam elevar em consequência do aumento de permeabilidade vascular intestinal. Nossos dados, todavia, não suportaram esta hipótese e eventualmente podem indicar que o período de $2 \mathrm{~h}$ de reperfusão intestinal não foi capaz de ajustar o sistema de drenagem de líquido.

Como hipótese, dada a semelhança do volume do fluxo linfático obtido entre os grupos OVx e com ovários preservados, sugerimos que a proteção de fêmeas às repercussões inflamatórias da IR intestinal não seja relacionada diretamente ao controle dos mecanismos de drenagem mesentérica. Vale salientar ainda que os dados obtidos por Yan et al. (2012), foram obtidos em animais do grupo controle e naqueles sob IR intestinal, notadamente durante a reperfusão intestinal. Como nossos estudos revelaram que na isquemia ocorre redução do fluxo linfático, no conjunto estes dados podem indicar que a disfunção observada por Yan et al. (2012) e confirmada em nossos estudos representem consequências de eventos que ocorreram durante o período de isquemia.

$\mathrm{Na}$ medida em que obtivemos a linfa dos animais, decidimos ampliar nossas análises e determinamos o número de leucócitos presentes nos 3 períodos de estudo (antes da isquemia - controle - durante a isquemia e após a reperfusão intestinal). Os dados obtidos revelaram que o número de leucócitos quantificados na linfa nesses 3 períodos somente diferiu nos grupos analisados no período de reperfusão intestinal, mostrando maior quantidade de células nos animais OVx comparado com aqueles com os ovários preservados.

Nossos resultados acerca da quantificação de citocinas na linfa mostraram que a IL-6 no grupo OVx se elevou à medida que decorre a IR intestinal e se mostrou significativamente diferente do grupo com os ovários preservados somente no período de reperfusão intestinal. Em relação à concentração de IL-10 pudemos notar um 
evento interessante. Esta citocina se manteve contínua no grupo com os ovários preservados durante os períodos analisados. Contudo, nos animais OVx os níveis desta citocina aumentaram de forma exuberante no período de reperfusão intestinal. Este aumento poderia representar um mecanismo de controle na magnitude da inflamação nos animais OVx.

Como mostramos que a ligação do ducto torácico em machos atenua a inflamação pulmonar e sistêmica (Cavriani et al., 2005), numa comparação entre os sexos nos parece que a obstrução do ducto linfático, em oposição aos machos, é prejudicial para fêmeas. Incorporando esta percepção aos resultados do presente estudo, podemos sugerir que o curso da inflamação causada pela IR intestinal pode ser distinto do já observado em machos. Talvez a obstrução do fluxo linfático desvie o transporte de produtos gerados durante a IR intestinal para o leito circulatório e se considerarmos o transporte de citocinas nos sistemas circulatório e linfático, é possível que na vigência da obstrução do fluxo, citocinas pró-inflamatórias ganhem acesso à circulação e sejam transportadas sistemicamente causando piora adicional do quadro inflamatório. Numa visão mais ampla das repercussões da IR intestinal, poderíamos supor que a piora do quadro associada à menor capacidade de fêmeas com ovários preservados de gerarem níveis elevados de IL-10, poderia ser responsável por afetar, de forma mais acentuada, o pulmão das fêmeas. Ressalte-se que o pulmão de machos obtidos após a IR intestinal, quando em cultura, são aptos a gerar mediadores inflamatórios (BREITHAUPT-FALOPPA et al., 2012). O mesmo pudemos observar recentemente com fêmeas OVx (Fantozzi et al., 2018). O significado desta capacidade é de muito interesse, pois revela que a inflamação pulmonar pode ser prolongada para períodos posteriores ao restabelecimento da oxigenação local causada pela reperfusão intestinal.

$\mathrm{Na}$ medida em que as células da linfa podem ser consideradas importantes moduladores da atividade do sistema imune e por ser bem estabelecido que o sistema imune inato pode ser ativado na IR intestinal decidimos realizar estudos adicionais a fim de traçar um perfil das células existentes na linfa. Para tanto, avaliamos as células do período controle (antes da IR intestinal) e no período de reperfusão intestinal

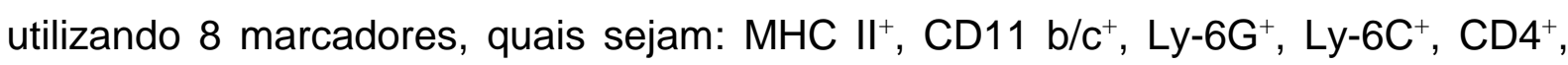
$\mathrm{CD}^{+}$e CD8 ${ }^{+}$. O conjunto de dados obtidos revelou que as populações de células que expressaram $\mathrm{MCH} \mathrm{I+}, \mathrm{CD} 11 \mathrm{~b} / \mathrm{c}^{+} \mathrm{MHC} \mathrm{II}, \mathrm{Ly}_{-} 6 \mathrm{C}^{+}$e $\mathrm{CD} 4^{+} \mathrm{CD}^{+}$apresentaram um 
perfil similar. Isto é, reduziram na linfa obtida durante reperfusão intestinal no grupo animais com os ovários preservados e mostraram-se em menor quantidade no grupo OVx na linfa obtido no período considerado controle em relação aos obtido com o grupo de animais com os ovários preservados. Estes dados poderiam sugerir que as células do sistema imune presente nos animais com ovários preservados na vigência da IR intestinal estão sendo drenadas da linfa para o sítio inflamatório, como as células B-1 (secretoras de imunoglobulinas), linfócitos $T$, macrófagos e células dendríticas. Em contraste, no grupo de animais OVx e submetidos a IR intestinal, estas células já estão em menor quantidade na linfa controle, permite considerar que o estradiol module o tráfego destas células. Por esta razão, não haveria células disponíveis para serem recrutadas e assim exacerbar a inflamação sistêmica como observado no grupo de animais com ovários preservados.

Estudos conduzidos por Liu et al. (2015), revelaram que a IR intestinal determina proliferação nas placas de Peyer de um sub-tipo de células $B$ imaturas as quais são fontes de citocinas pró-inflamatórias via ativação de $T L R 4 / N_{k} B$. Nesse contexto a IR intestinal pode causar alterações locais, notadamente na placa de Peyer contribuindo desta forma para o desenvolvimento da lesão tecidual inflamatória e sistêmica (ZHANG et al., 2004; LINFERT et al., 2009). O fato de as células B1 (CD5+) estarem constitutivamente mais elevadas na linfa dos animais OVx poderia sugerir que a geração de anticorpo naturais bem como a geração de IgM (DONO et al., 2004) poderiam estar mais acentuadas em OVx do que em não-OVx e desta forma exercer algum efeito protetor do intestino. Ainda, as células B1 participam do controle de geração de IgA pelos plasmócitos no intestino e poderiam proteger o organismo dos efeitos lesivos da translocação bacteriana (BERLAND \& WORTIS, 2002).

Aliás, como já mencionado a translocação bacteriana é um dos eventos comuns observados na inflamação sistêmica decorrente de lesões no intestino (FLOHÉ et al., 2008) nas quais a IR intestinal pode ocupar lugar de destaque. $\mathrm{Na}$ medida em que após a IR intestinal há tendência de redução das células B1 na linfa e, considerando a função dessas células na imunologia do intestino, é possível sugerir a existência de um desvio de transporte dessas células para outras vias que a linfa e assim sua presença mais localizada protegeria o intestino dos efeitos da IR intestinal. Assim, tal proteção seria útil na prevenção de efeitos sistêmicos mais deletérios. Visto que o intestino é considerado o "motor da inflamação" (DEITCH et al., 2006) em 
modelos de lesão intestinal então a elevada expressão de CD5 ${ }^{+}$e a tendência de sua redução após a IR intestinal refletiria um mecanismo de monitoramento do sistema imune frente a estímulos nocivos que ocorram no intestino.

A IR intestinal por ser um evento no qual os neutrófilos e estas células expressam Ly6G+. Estudos revelam que este marcador presente em membrana de neutrófilos pode mediar seu recrutamento para um foco inflamatório (Lee et al., 2013). De forma geral é aceito que este marcador reflete a presença de neutrófilos e mais, que em conjunto com a $\beta 2$ integrina medeia o recrutamento para o local da infamação. Já o marcador $\mathrm{Ly} 6 \mathrm{C}^{+}$caracteriza basicamente mononucleares, notadamente macrófagos. Assim o corpo dos nossos resultados neste sentido sugere que os eventos inflamatórios locais na IR intestinal são diferencialmente modulados. De forma geral podemos inferir que durante a IR intestinal em fêmeas OVx a linfa é rica em neutrófilos e com menor intensidade de macrófagos. Nossos estudos também revelaram a existência de uma subpopulação de células aptas a expressarem ambos marcadores, constituindo assim uma eventual população mista a qual não identificamos. Todavia é interessante considerar que esta população aparentemente é constitutiva, visto estar presente na linfa controle de ambos os grupos, porém em menor quantidade nas fêmeas OVx.

É interessante lembrar que a circulação de linfócitos a partir das placas de Payer em direção aos linfonodos é mediada pelo linfonodo mesentérico e que o seu o retorno à circulação se dá via ducto linfático torácico. Neste retorno, os linfócitos podem se alojar na lâmina própria e na mucosa intestinal (JOHNSON \& KUDSK, 1999). Yang et al., (2012) mostraram em um interessante estudo que existe redução do fluxo da linfa mesentérica e da população de linfócitos na linfa após a IR intestinal. Estes autores observaram que a população de linfócitos se eleva no trato gastrintestinal como forma de ajustar a resposta imune. Em estudos posteriores aos destes autores (YAN et al., 2014), revelaram aumento de CD4+ e CD8 ${ }^{+}$no intestino como forma de proteção da mucosa intestinal das repercussões locais e sistêmicas da IR intestinal. Embora havendo indícios de linfócitos T e B, nossos estudos não evoluíram no sentido de indicar o papel dos linfócitos em nosso modelo bem como não temos elementos para indicar o significado do maior número de células CD4+ encontrado na linfa das OVx. Todavia, vale lembrar que o aumento de leucócitos no 
intestino causada pela IR intestinal é evento que pode se associar à indução de lesão da mucosa concorrendo, portanto para infiltração bacteriana (FUKATSU et al., 2006).

À luz dos dados gerados neste estudo podemos montar um cenário no qual as repercussões da IR intestinal poderiam decorrer de distintas características do microambiente gastrintestinal entre fêmeas com ovários ou com obstrução do fluxo linfático e ainda nossos achados poderão contribuir para a compreensão de mecanismos subjacentes às diferenças encontradas no curso da doença inflamatória causada por eventos isquêmicos intestinais seguidos de sua reperfusão e eventualmente, também para outras condições inflamatórias do sistema gastrintestinal que venham a afetar, com distinta prevalência mulheres hormonalmente ativas ou não. 


\section{CONCLUSÃO}

- A IR intestinal em fêmeas com ovários removidos aumenta a permeabilidade do epitélio e endotélio vascular intestinal, causando algum grau de lesão no intestino.

- O intestino visto como o órgão central no desencadeamento das lesões em órgãos distantes, aparentemente medeia a intensidade inflamatória por mecanismos que envolvem o recrutamento celular e o aumento de permeabilidade vascular e macromolecular intestinal.

- Existe uma modulação da atividade funcional de neutrófilos na IR intestinal pelo estradiol uma vez que, ao tratarmos fêmeas OVx previamente ou terapeuticamente com este esteroide observamos menor atividade de MPO no intestino e inibição de sua migração expontânea.

- Fêmeas com ovários preservados, apesar de serem menos propensas a desenvolver resposta inflamatória após a IR intestinal, expressam, com algum grau, genes moduladores da resposta inflamatória no mesentério, como o Ccr4 e o Mif.

- A falta de hormônios sexuais circulantes ou sua redução a valores abaixo dos fisiológicos pode interferir com a atividade funcional da medula óssea elevando o seu número de células o qual não foi corrigido pelos protocolos de tratamentos propostos com estradiol.

- A IR intestinal desencadeou inflamação sistêmica nos animais OVx com aumento de IL-10, MIP-1a, MIP-2, MCP-1, CINC-1, IP-10 e leptina.

- O momento da administração do estradiol (IR E30' ou IR E24h) pode ser decisivo para modificar o curso da geração de mediadores de forma diferente.

- Apesar de encontrarmos redução na atividade de MPO e concentração de azul de Evans no intestino de animais OVx com o ducto linfático ligado após a IR intestinal, não pudemos observar outros dados que evidenciassem redução na resposta inflamatória.

- A obstrução do ducto linfático em fêmeas submetidas à IR intestinal causou inflamação local e sistêmica antes não observada em animais mantidos com o ducto linfático torácico intacto.

- A IR intestinal reduz drasticamente o volume de linfa circulante em animais OVx e não-OVx e, também observamos aumento na quantidade de células presentes na linfa das fêmeas OVx no momento da reperfusão. 
- Células do sistema imune presente nos animais com ovários preservados na vigência da IR intestinal estão sendo drenadas da linfa para o sítio inflamatório. Em contraste, no grupo de animais OVx e submetidos a IR intestinal, estas células já estão em menor quantidade na linfa controle, permitindo considerar que o estradiol module $\mathrm{o}$ tráfego destas células.

- Durante a IR intestinal em fêmeas OVx a linfa é rica em neutrófilos e com menor intensidade de macrófagos.

Em síntese, os nossos resultados mostraram que fêmeas com ovários intactos se mostram mais protegidas aos efeitos lesivos gerados na vigência da IR intestinal do que as fêmeas com ovários removidos. As lesões locais causadas pela IR intestinal alteram a morfologia e funcionalidade intestinal em animais OVx caracterizado pelo acúmulo de células e mediadores inflamatórios. Em vias sistêmicas observamos maior mobilização de leucócitos, notadamente de neutrófilos e, mediadores inflamatórios como: IL-10, MIP-1a, MIP-2, MCP-1, CINC-1 e leptina. Os tratamentos com estradiol exerceram funções protetoras distintas e dependentes do momento de sua administração. Sendo que, o tratamento com estradiol $24 \mathrm{~h}$ antes da IR intestinal parece ser mais eficiente do que o administrado com 30min de isquemia. Em relação a participação do sistema linfático, nossos dados sugerem que a obstrução do ducto linfático em fêmeas exacerba a inflamação gerada pela IR intestinal e que, o estradiol exerça algum controle sobre os componentes da linfa drenada na vigência da IR intestinal. 


\section{REFERÊNCIAS ${ }^{1}$}

ADAMS, C. A. JR.; MAGNOTTI, L. J.; XU, D. Z.; LU, Q.; DEITCH, E. A. Acute lung injury after hemorrhagic shock is dependent on gut injury and sex. Am. Surg., v. 66, p. $905-912,2000$.

ADAMS, C. A. JR.; SAMBOL, J. T.; XU, D. Z.; LU, Q.; GRANGER, D. N.; DEITCH, E. A. Hemorrhagic shock induced up-regulation of P-selectin expression is mediated by factors in mesenteric lymph and blunted by mesenteric lymph duct interruption. J. Trauma, v. 51, p. 625-631, 2001.

ANANTHAKRISHNAN, P.; COHEN, D. B.; XU, D. Z.; LU, Q.; FEKETEOVA, E.; DEITCH, E. A. Sex hormones modulate distant organ injury in both a trauma/hemorrhagic shock model and a burn model. Surgery, v. 1371, p. 56-65, 2005.

ANGELE, M. K.; SCHWACHA, M. G.; AYALA, A.; CHAUDRY, I. H. Effect of gender and sex hormones on immune responses following shock. Shock, v. 14, p. 81-90, 2000.

ANGELE, M. K.; FRANTZ, M. C.; CHAUDRY, I. H. Gender and sex hormone influence the response to trauma and sepsis - potential therapeutic approaches. Clinics, v. 61, p. 479-488, 2006.

ATTUAWAYBI, B.O.; KOZAR, R.A.; MOORE-OLUFEMI, S.D.; SATO, N.; HASSOUN, H.T.; WEISBRODT, N.W.; MOORE, F.A. Heme oxygenase-1 induction by hemin protects against gut ischemia/reperfusion injury. Am. J. Physiol., v. 118, p. 53$57,2004$.

BERLAND, R.; WORTIS, H. H. Origins and functions of B-1 cells with notes on the role of CD5. Annual Rev. Immunology, v. 20, p. 253-300, 2002.

BEUK, R. J.; HEINEMAN, E.; TANGELDER, G. J.; QUAEDACKERS, J. S.; MARKS, W. H.; LIEBERMAN, J. M.; OUDE EGBRINK, M. G. Total warm ischemia and reperfusion impairs flow in all rat gut layers but increases leukocyte-vessel wall interactions in the submucosa only. Ann. Surg., v. 231, p. 96-104, 2000.

BREITHAUPT-FALOPPA, A. C.; VITORETTI, L. B.; COELHO, F. R.; DOS SANTOS FRANCO, A. L.; DOMINGOS, H. V.; SUDO-HAYASHI, L. S.; OLIVEIRAFILHO, R. M.; TAVARES DE LIMA, W. Nitric oxide mediates lung vascular permeability and lymph-borne IL-6 after an intestinal ischemic insult. Shock, v. 32, p. 55-61, 2009.

BREITHAUPT-FALOPPA, A. C.; VITORETTI, L. B.; CAVRIANI, G.; LINO-DOSSANTOS-FRANCO, A.; SUDO-HAYASHI, L. S.; OLIVEIRA-FILHO, R. M.; VARGAFTIG, B. B.; TAVARES-DE-LIMA, W. Intestinal lymph-borne factors induce

${ }^{1}$ De acordo com:

ASSOCIAÇÃO BRASILEIRA DE NORMAS TÉCNICAS. NBR 6023: informação e documentação: referências: elaboração. Rio de Janeiro, 2002. 
lung release of inflammatory mediators and expression of adhesion molecules after an intestinal ischemic insult. J. Surg. Res., v. 176, p. 195-201, 2012.

BREITHAUPT-FALOPPA, A.C.; FANTOZZI, E.T.; ASSIS-RAMOS, M.M.; VITORETTI, L.B.; COUTO, G.K.; ROSSONI, L.V.; OLIVEIRA-FILHO, R.M.; VARGAFTIG, B.B.; TAVARES-DE-LIMA, W. Protective effect of estradiol on acute lung inflammation induced by a intestinal ischemic insult is dependent on nitric oxide. Shock. v. 40, n. 3, p. 203-209, 2013.

BRUNO, A.; CONUS, S.; SCHMID, I.; SIMON, H. U. Apoptotic pathways are inhibited by leptina receptor activation in neutrophils. J. Immunology, v. 174, p. 80908096, 2005.

BULKLEY, G. B.; KVIETYS, P. R.; PARKS, D. A.; PERRY, M. A.; GRANGER, D. N. Relationship of blood flow and oxygen consumption to ischemic injury in the canine small intestine. Gastroenterology, v. 89(4), p. 852-857, 1985.

CADENAS, S. ROS and redoz signaling in myocardial ischemia-reperfusion injury and cardioprotection. Free Radical Biological Med., v. 117, p. 76-89, 2018.

CAMPBELL SJ, HUGHES PM, IREDALE JP, WILCOCKSON DC, WATERS S, DOCAGNE F, PERRY VH, ANTHONY DC. CINC-1 is an acute-phase protein induced by focal brain injury causing leukocyte mobilization and liver injury. FASEB Journal, v. 17(9), p. 1168-1170, 2003.

CAVRIANI, G.; OLIVEIRA-FILHO, R. M.; TREZENA, A. G.; DA SILVA, Z. L.; DOMINGOS, H. V.; DE ARRUDA, M. J.; JANCAR, S.; TAVARES DE LIMA, W. Lung microvascular permeability and neutrophil recruitment are differently regulated by nitric oxide in a rat model of intestinal ischemia-reperfusion. Eur. J. Pharmacol., v. 494, p. 241-249, 2004.

CAVRIANI, G.; DOMINGOS, H. V.; SOARES, A. L.; TREZENA, A. G.; LIGEIROOLIVEIRA, A. P.; OLIVEIRA-FILHO, R. M.; SUDO-HAYASHI, L. S.; TAVARES DE LIMA, W. Lymphatic system as a path underlying the spread of lung and gut injury after intestinal ischemia/reperfusion in rats. Shock, v. 23(4), p. 330-336, 2005.

CAVRIANI, G.; DOMINGOS, H. V.; OLIVEIRA-FILHO, R. M.; SUDO-HAYASHI, L. S.; VARGAFTIG, B. B.; DE LIMA, W. T. Lymphatic thoracic duct ligation modulates the serum levels of IL-1beta and IL-10 after intestinal ischemia/reperfusion in rats with the involvement of tumor necrosis factor alpha and nitric oxide. Shock, v. 27(2), p. 209213, 2007.

CERQUEIRA, N.F.; HUSSNI, C.A.; YOSHIDA, W.B. Pathophysiology of mesenteric ischemia/reperfusion: a review. Acta Cir. Bras., v. 20, p. 336-343, 2005.

CHAUDRY, I. H.; SAMY, T. S.; SCHWACHA, M. G.; WANG, P.; RUE, L. W.; BLAND, K. I. Endocrine targets in experimental shock. The Journal of Trauma, v. 54, p. 118-125, 2003.

CHANG, J.X.; CHEN, S.; MA, L.P.; JIANG, L.Y.; CHEN, J.W.; CHANG, R.M.; WEN, L.Q.; WU,W.; JIANG, Z.P; HUANG, Z.T. Functional and morphological changes of the 
gut barrier during the restitution process after hemorrhagic shock. World $\mathbf{J}$. Gastroent., v. 11, n. 35, p. 5485-5491, 2005.

CHEN, L. W.; EGAN, L.; LI, Z. W.; GRETEN, F. R.; KAGNOFF, M. F.; KARIN, M. The two faces of IKK and NF-kappaB inhibition: prevention of systemic inflammation but increased local injury following intestinal ischemia-reperfusion. Nat. Med., v. 9, p. 575-581, 2003.

COELHO, F. R.; CAVRIANI, G.; SOARES, A. L.; TEIXEIRA, S. A.; ALMEIDA, P. C.; SUDO-HAYASHI, L. S.; MUSCARÁ, M. N.; OLIVEIRA-FILHO, R. M.; VARGAFTIG, B. B.; TAVARES-DE-LIMA, W. Lymphatic-borne IL-1beta and the inducible isoform of nitric oxide synthase trigger the bronchial hyporesponsiveness after intestinal ischema/reperfusion in rats. Shock, v. 28, p. 694-699, 2007.

COX, A.A.; VARMA, A.; VERTEGEL, A.; BARRY, J.; BANIK, N. Nanoparticle estrogen in rat spinal cord injury elicits rapid anti-inflammatory effects in plasma, CSF and tissue. J. Neurotrauma, 2015.

DE JONG, P. R.; GONZÁLEZ-NAVAJAS, J. M.; JANSEN, N. J. The digestive tract as the origin of systemic inflammation. Critical Care, v. 20, p. 279, 2016.

DEITCH, E. A.; XU, D.; FRANKO, L.; AYALA, A.; CHAUDRY, I. H. Evidence favoring the role of the gut as a cytokine-generating organ in rats subjected to hemorrhagic shock. Shock, v. 1, p. 141-145, 1994.

DEITCH, E.A. Role of the gut lymphatic system in multiple organ failure. Curr. Opin. Crit. Care., v. 7, p. 02-98, 2001.

DEITCH, E. A.; LIVINGSTON, D. H.; LAVERY, R. F.; MONAGHAN, S. F.; BONGU, A.; MACHIEDO, G. W. Hormonally active women tolerate shock-trauma better than do men: a prospective study of over 4000 trauma patients. Ann. Surg., v. 246, p. 447453, 2007.

DEITCH, E. A.; FEKETEOVA, E.; LU, Q.; ZAETS, S.; BEREZINA, T. L.; MACHIEDO, G. W.; HAUSER, C. J.; LIVINGSTON, D. H.; XU, D. Z. Resistance of the female, as opposed to the male, intestine to IR-mediated injury is associated with increased resistance to gut-induced distant organ injury. Shock, v. 29, p. 78-83, 2008a.

DEITCH, E.A.; CHU, H.; XU, D.A.Z. Organ blood flow and the central hemodynamic response are better preserved in female, as opposed to the male rats, after traumahemorrhagic shock. J. Trauma, v. 65n. 3, p. 566-572, 2008 b.

DIEBEL, L. N.; LIBERATI, D. M. Estrogen impairs pulmonary microvascular response to gut-derived mediators after shock conditions. J. Trauma, v. 71, p. 656662, 2011.

DOSSETT, L. A.; SWENSON, B. R.; HEFFERNAN, D.; BONATTI, H.; METZGER, R.; SAWYER, R. G.; MAY, A. K. High levels of endogenous estrogens are associated with death in the critically injured adult. J. Trauma, v. 64, p. 580-585, 2008. 
DOUCET, D.; BADAMI, C.; PALANGE, D.; BONITZ, R.P.; LU, Q.; XU, D.Z.; KANNAN, K.B.; COLORADO, I.; FEINMAN, R.; DEITCH, E.A. Estrogen receptor Hormone agonist limit trauma hemorrhage shock-induced gut and lung injury in rats. PLoS One, v. 5, n. 2, p. e9421, 2010.

EMR, B.; SADOWSKY, D.; AZHA, N.; GATTO, L.A.; AN, G.; NIEMAN, G.F.; VODOVOTZ, Y. Removal of inflammatory ascites is associated with dynamic modification of local and systemic inflammation along with preventon of acute long injury: in vivo and in silico studies. Shock, v. 41, p. 317-323, 2014.

FANTOZZI, E.T. Hormônios sexuais femininos como moduladores da geração de mediadores inflamatórios em modelo experimental de isquemia e reperfusão intestinal. 116f. Tese (Mestrado em Farmacologia). Instituto de Ciências Biomédicas, Universidade de São Paulo. São Paulo, 2013.

FANTOZZI, E. T.; BREITHAUPT-FALOPPA, A. C.; RICARDO-DA-SILVA, F. Y.; RODRIGUES-GARBIN, S.; ROMERO, D. C.; DA SILVA RODRIGUES, A.; RIFFOVASQUEZ, Y.; TAVARES-DE-LIMA, W. Estradiol mediates the long-lasting lung inflammation induced by intestinal ischemia and reperfusion. J. Surg. Res., v. 221, p. 1-7, 2018.

FANTUZZI, G. Adipose tissue, adipokines and inflammation. J. Allergy Clin. Immunology, v. 115, p. 911-919, 2005.

FILARDO, E. J.; QUINN, J. A.; BLAND, K. I.; FRACKELTON JR, A. R. Estrogeninduced activation of Erk-1 and Erk-2 requires the G protein-coupled receptor homolog, GPR30, and occurs via trans-activation of the epidermal growth factor receptor through release of HB-EGF. Mol. Endocrinol., v. 14, p. 1649-1660, 2000.

FILARDO, E. J. GPER and ER: estrogen receptors with distinct biological roles in breast cancer. Immunol. Endocr. Metab. Agents Med. Chem., v. 11, p. 243-254, 2011.

FISH, E. N. The X-files in immunity: sex-based differences predispose immune responses. Nature Reviews Immunology. v. 8, p. 737-744, 2008.

FLOHÉ, S. B.; PLOHÉ, S.; SCHADE, F. U. Invited review: deterioration of the imune system after trauma: signals and cellular mechanisms. Innate Immunology, v. 14, p. 333-344, 2008.

FRAZIER-JESSEN, M.R.; KOVACS, E.J. Estrogen modulation of JE/monocyte chemoattractant protein-1 mRNA expression in murine macrophages. J. Immunol., v. 154, p. 1838-1845, 1995.

FRINK, M.; PAPE, H.C.; VAN GRIENSVEN, M.; KRETTEK, C.; CHAUDRY, I. H.; HILDEBRAND, F. Influence of sex and age on mods and cytokines after multiple injuries. Shock, v. 27, p. 151-156, 2007.

FUKATSU, K.; SAKAMOTO, S.; HARA, E.; UENO, C.; MAESHIMA, Y.; MATSUMOTO, I.; MOCHIZUKI, H.; HIRAIDE, H. Gut ischemia-reperfusion affects gut 
mucosal immunity: a possible mechanism for infectious complications after severe surgical insults. Critical Care Med., v. 34, p. 182-187, 2006.

FUKUMOTO, T.; TAWA, M.; YAMASHITA, N.; OHKITA, M.; MATSUMURA Y. Protective effects of 17beta-estradiol on post-ischemic cardiac dysfunction and norepinephrine overflow through the non-genomic estrogen receptor/nitric oxidemediated pathway in the rat heart. European J. Pharmacol., v. 699, p. 74-80, 2013.

GANNON, C. J.; NAPOLITANO, L. M.; PASQUALE, M.; TRACY, J. K.; MCCARTER, R. J. A statewide population-based study of gender differences in trauma: validation of a prior single-institution study. J. Am. Coll. Surg., v. 195, p. 1118, 2002.

GANNON, C. J.; PASQUALE, M.; TRACY, J. K.; MCCARTER, R. J.; NAPOLITANO, L. M. Male gender is associated with increased risk for postinjury pneumonia. Shock, v. 21, p. 410-414, 2004.

GOLDBLUM, S.E.; WU, K.M.; JAY, M. Lung myeloperoxidase as a measure of pulmonary leukostasis in rabbits. J. Appl Physiol., v. 59, n. 6, p. 1978-1985, 1985.

GROSSMAN, C. J. Interactions between the gonadal steroids and the immune system. Science, v. 227, p. 257-261, 1985.

GROTZ, M.R.W.; DEITCH, E.A.; DING, J.; XU, D.Z.; HUANG, Q.H.; REGEL, G. Intestinal cytokine response after gut ischemia: role of gut barrier failure. Ann. Surg., v. 229 , n. 4 , p. $478-486,1999$.

GUAN, Y.; WORRELL, R. T.; PRITTS, T. A.; MONTROSE, M. H. Intestinal ischemia-reperfusion injury: reversible and irreversible damage imaged in vivo. Am. J. Physiol. Gastrointest. Liver Physiol., v. 297, p. G187-G196, 2009.

HE, G. Z.; ZHOU, K. G.; ZHANG, R.; WANG, Y. K.; CHEN, X. F. Impact of intestinal ischemia/reperfusion and lymph drainage on distant organs in rats. World $\mathbf{J}$. Gastroenterol., v. 18, p. 7271-7278, 2012.

HILDEBRAND, F.; HUBBARD, W. J; CHOUDHRY, M. A.; THOBE, B. M.; PAPE, H. C.; CHAUDRY, I. H. Effects of 17beta-estradiol and flutamide on splenic macrophages and splenocytes after trauma-hemorrhage. Cytokine, v. 36, p. 107-114, 2006.

HOMMA, H.; HOY, E.; DA-ZHONG, X.; LU, X.; FEINMAN, R.; DEITCH, E.A. The female intestine is more resistant than the male intestine to gut injury and inflammation when subjected to conditions associated with shock states. Am. J. Physiol. Gastrointest. Liver Physiol., v. 288, p. G466-G472, 2005.

JARRAR, D.; WANG, P.; KNÖFERL, M. W.; KUEBLER, J. F.; CIOFFI, W. G.; BLAND, K. I.; CHAUDRY, I. H. Insight into the mechanism by which estradiol improves organ functions after trauma-hemorrhage. Surgery, v. 128, p. 246-252, 2000.

JOHNSON, K. K. Nutrition and intestinal mucosal immunity. Clin. Nutr., v. 18, p. 337-344, 1999. 
KALOGERIS, T.; BAINES, C. P.; KRENZ, M.; KORTHUIS, R. J. Ischemia/Reperfusion. Compr. Physiology, v. 6, p. 113-170, 2016.

KINROSS, J.; WARREN, O.; BASSON, S.; HOLMES, E.; SILK, D.; DARZI, A. NICHOLSON, J.K. Intestinal ischemia/reperfusion injury: defining the role of the gut microbiome. Biomark Med., v. 3, p. 175-192, 2009.

KNÖFERL, M. W.; JARRAR, D.; ANGELE, M. K.; AYALA, A.; SCHWACHA, M. G.; BLAND, K. I.; CHAUDRY, I. H. 17beta-estradiol normalizes immune responses in ovariectomized females after trauma-hemorrhage. Am. J. Physiol. Cell. Physiol., v. 281, p. 1131-1138, 2001.

KNÖFERL, M. W.; ANGELE, M. K.; DIODATO, M. D.; SCHWACHA, M. G.; AYALA, A.; CIOFFI, W. G.; BLAND, K. I.; CHAUDRY, I. H. Female sex hormones regulate macrophage function after trauma-hemorrhage and prevent increased death rate from subsequent sepsis. Annals of Surgery, v. 235, p. 105-112, 2002.

KNOOP, S.T.; SKREDE, S.; LANGELAND, N.; FLAATTEN, H.K. Epidemiology and impacto $\mathrm{n}$ all-cause mortality of sepsis in Norwegian hospitals: a national retrospective study. PloS One, v. 12, p. e0187990, 2017.

KNUDSEN, A. R.; KANNERUP, A. S.; GRONBAEK, H.; ANDERSEN, K. J.; FUNCH-JENSEN, P.; FRYSTYK, J.; FLYVBJERG, A.; MORTENSEN, F. Effects of ischemic pre- and postconditioning on HIF-1 $\alpha$, VEGF and TGF- $\beta$ expression after warm ischemia and reperfusion in the rat live. Comp. Hepatol., v. 10, p. 3, 2011.

KOH, K. K.; SON, J. W.; AHN, J. Y.; LEE, S. K.; HWANG, H. Y.; KIM, D. S.; JIN, D. K.; AHN, T. H.; SHIN, E. K. Effect of hormone replacement therapy on nitric oxide bioactivity and monocyte chemoattractant protein-1 levels. Int. J. Cardiol., v. 81, p. 43-50, 2001.

KUEBLER, J. F.; JARRAR, D.; BLAND, K. I.; RUE, L.; WANG, P.; CHAUDRY, I. H. Progesterone administration after trauma and hemorrhagic shock improves cardiovascular responses. Critical Care Med., v. 31, p. 1786-1793, 2003.

LA CAVA, A.; MATARESE, G. The weight of leptina in immunity. Nat. Rev. Immunology, v. 4, p. 371-379, 2004.

LAM, S. K.; HUI, W. M.; CHING, C. K. Peptic ulcer disease: epidemiology, pathogenesis and etiology. Bockus Gastroenterology, v. 5, p. 700-748, 1994.

LEE, P.Y.; WANG, J. X.; PARISINI, E.; DASCHER, C. C.; NIGROVIC, P. A. Ly6 family proteins in neutrophil biology. Journal of Leukocyte Biology, v. 94, p. 585594, 2013.

LI, L.; HUANG, L.; VERGIS, A.L.; YE, H.; BAJWA, A.; NARAYAN, V.; STRIETER, R.M.; ROSIN, D.L.; OKUSA, M.D. IL-17 produced by neutrophils regulates IFNgamma-mediated neutrophil migration in mouse kidney ischemia-reperfusion injury. J. Clin. Invest., v. 120, n. 1, p. 331-342, 2010. 
LIGEIRO DE OLIVEIRA, A. P.; OLIVEIRA-FILHO, R. M.; DA SILVA, Z. L.; BORELLI, P.; TAVARES DE LIMA, W. Regulation of allergic lung inflammation in rats: interaction between estradiol and corticosterone. Neuroimmunomodulation, v. 11(1), p. 20-27, 2004.

LINFERT, D.; CHOWDHRY, T.; RABB, H. Lymphocytes and ischemia-reperfusion injury. Transplant Review, v. 23, 1-10, 2009.

LIU, L.; TAN, Q.; HU, B.; WU, H.; WANG, C.; TANG, C. Somatostatin Inhibits the Production of Interferon-c by Intestinal Epithelial Cells During Intestinal IschemiaReperfusion in Macaques. Dig. Dis. Sci., v. 59, p. 2423-2432, 2014.

MAGGIOLINI, M.; VIVACQUA, A.; FASANELLA, G.; RECCHIA, A. G.; SISCI, D.; PEZZI, V.; MONTANARO, D.; MUSTI, A. M.; PICARD, D.; ANDÒ, S. The G proteincoupled receptor GPR30 mediates $c$-fos up-regulation by 17 beta-estradiol and phytoestrogens in breast cancer cells. J. Biol. Chem., v. 279, p.27008-27016, 2004.

MAGNOTTI, L. J.; UPPERMAN, J. S.; XU, D. Z.; LU, Q.; DEITCH, E. A. Gut-derived mesenteric lymph but not portal blood increases endothelial cell permeability and promotes lung injury after hemorrhagic shock. Ann. Surg., v. 228, p. 518-527, 1998.

MAGNOTTI, L. J.; XU, D. Z.; LU, Q.; DEITCH, E. A. Gut-derived mesenteric lymph: a link between burn and lung injury. Arch. Surg., v. 134, p. 1333-1340, 1999.

MAY, R. C. Gender, immunity and the regulation of longevity. Bioessays., v. 29, p. 795-802, 2007.

MCDERMOTT, W.V.; BROWN, H. Ascites. Annu. Rev. Med., v. 15, p. 79-92, 1964.

MELDRUM, D. R. Estrogen increases protective proteins following trauma and hemorrhage. American Journal of Physiology. Regulatory, Integrative and Corporative Physiology, v. 290, p. 809-811, 2006.

MENDELSOHN, M. E.; KARAS, R. H. Mechanisms of disease: The protective effects of estrogen on the cardiovascular system. N. Engl. J. Med., v. 340, p. 1801$1811,1999$.

MENGER, M. D.; RÜCKER, M.; VOLLMAR, B. Capillary dysfunction in striated muscle ischemia/reperfusion: on the mechanisms of capillary "no-reflow". Shock, v. 8, p. 2-7, 1997.

MEYER, M.J.; CAPUCO, A.V.; BOISCLAIR, Y.R.; VAN AMBURGH, M.E.; Estrogen-dependent responses of the mammary fat pad in prepubertal dairy heifers. J. Endocrinol., v. 190, n. 3, p. 819-827, 2006.

MIYAGI, M.; AOYAMA, H.; MORISHITA, M.; IWAMOTO, Y. Effects of sex hormones on chemotaxis of human peripheral polymorphonuclear leukocytes and monocytes. J. Periodontol., v. 63, p. 28-32, 1992.

MOEINPOUR, F.; CHOUDHRY, M.A.; TIMARES, L.; SCHWACHA, M.G.; CHAUDRY, I.H. 17 Beta-estradiol normalizes Toll receptor 4, mitogen activated protein 
kinases and inflammatory responses in epidermal keratinocytes following traumahemorrhage. Mol Immunol., v. 44, n. 13, p. 3317-3323, 2007.

NARITA, K.; KUWABARA, Y.; FUJII, Y. Lung Injury After Intestinal IschemiaReperfusion May Be Avoided by the Reduced Absorption of Locally Produced Cytokines. Surg. Today, v. 34, p. 937-942, 2004.

NEWMAN, S. L.; HENSON, J. E.; HENSON, P. M. Phagocytosis of senescente neutrophils by human monocyte-derived macrophages and rabbit inflammatory macrophages. Journal of Experimental Medicine, v. 156, p. 430-432, 1982.

O'LONE, R.; FRITH, M. C.; KARLSSON, E. K.; HANSEN, U. Genomic targets of nuclear estrogen receptors. Mol. Endocrinol., v. 18, p. 1859-1875, 2004.

PAGE, C.; PITCHFORD, S. Neutrophil and platelet complexes and their relevance to neutrophil recruitment and activation. Int. Immunopharmacol., v. 17, p. 1176-1184, 2013.

PALOMBIT, K.; MENDES, C.E.; TAVARES-DE-LIMA, W.; SILVEIRA, M.P.; CASTELUCCI, P. Effects of ischemia and reperfusion on subpopulations of rat enteric neurons expressing the P2X7 receptor. Dig Dis Sci., v. 58, n. 12, p. 3429-3439, 2013.

PARKS, D. A.; GRANGER, D. N. Contributions of ischemia and reperfusion to mucosal lesion formation. Am. J. Physiol., v. 250, p. G749-G753, 1986.

PEOC’H, K.; NUZZO, A.; GUEDJ, K.; PAUGAM, C.; CORCOS, O. Diagnosis biomarkers in acute intestinal ischemic injury: so close, yet so far. Clin. Chem. Lab. Med., v. 56, p. 373-385, 2018.

PIERDOMINICI, M.; MASELLI, A.; COLASANTI, T.; GIAMMARIOLI, A. M.; DELUNARDO, F.; VACIRCA, D.; SANCHEZ, M.; GIOVANNETTI, A.; MALORNI, W.; ORTONA, E. Estrogen receptor profiles in human peripheral blood lymphocytes. Immunol. Lett., v. 132, p. 79-85, 2010.

POPE, M.R.; HOFFMAN, S.M.; TOMLINSON, S.; FLEMING, S.D. Complement regulates TLR4-mediated inflammatory responses during intestinal isquemia reperfusion. Mol. Immunol., v. 48, p. 356-364, 2010.

PROSSNITZ, E. R.; ARTERBURN, Z. B.; SMITH, H. O.; OPREA, T. I.; SKLAR, L. A.; HATHAWAY, $H$. J. Estrogen signaling through the transmembrane $G$ proteincoupled receptor GPR30. Annu. Rev. Physiol., v. 70, p. 165-190, 2008.

QIN, X.; SHETH, S.U.; SHARPE, S.M.; DONG, W.; LU, Q.; XU, D.; DEITCH, E.A. The mucus layer is critical in protecting against ischemia/reperfusion-mediated gut injury and in the restitution of gut barrier function. Shock, v. 35, n. 3, p. 275-281, 2011.

RAMOS, G.; HOFMANN, U.; FRANTZ, S. Myocardial fibrosis through the lenses of T-cell biology. J. Molecular Cell Cardiology, v. 92, p. 41-45, 2016. 
RAPPOLD, J. F.; COIMBRA, R.; HOYT, D. B.; POTENZA, B. M.; DALE, F.; HOLBROOK, T. Female gender does not protect blunt trauma patients from complications and mortality. J. Trauma, v. 53, p. 436-441, 2002.

REVANKAR, C. M.; CIMINO, D. F.; SKLAR, L. A.; ARTERBURN, J. B.; PROSSNITZ, E. R. A transmembrane intracellular estrogen receptor mediates rapid cell signaling. Science, v. 307, p. 1625-1630, 2005.

RIFFO-VASQUEZ, Y.; MAN, F.; PAGE, C.P. Doxofylline, a novofylline inhibits lung inflammation induced by lipopolysacharide in the mouse. Pulm. Pharmacol. Ther., v. 27, n. 2, p. 170-178, 2014.

RUWART, M. J.; KLEPPER, M. S.; RUSH, B. D. Adrenergic and cholinergic contributions to decreased gastric emptying, small intestinal transit, and colonic transit in the postoperative ileus rat. J. Surg. Res., v. 29, p. 126-134, 1980.

SCARABELLI, T. M.; PASINI, E.; STEPHANOU, A.; COMINI, L.; CURELLO, S.; RADDINO, R.; FERRARI, R.; KNIGHT, R.; AND LATCHMAN, D. S. Urocortin promotes hemodynamic and bioenergetic recovery and improves cell survival in the isolated rat heart exposed to ischemia/reperfusion. J. Am. Coll. Cardiol., v. 40, p. 155161, 2002.

SCHABOWSKI, J.; PITERA, J. Peptic ulcer among rural population in a selected region of south-eastern Poland. Ann. Agric. Environ. Med., v. 11, p. 323-327, 2004.

SHARAWY, N.; RIBBACK, S.; AL-BANNA, N.; LEHMANN, C.; KERN, H.; WENDT, M.; CERNY, V.; DOMBROWSKI, F.; PAVLOVIC, D. Estradiol receptors agonists induced effects in rat intestinal microcirculation during sepsis. Microvasc. Res., v. 85, p. 118-127, 2013.

SHEH, A.; GE, Z.; PARRY, N.M.; MUTHUPALANI, S.; RAGER, J.E.; RACZYNSKI, A.R.; MOBLEY, M.W.; MCCABE, A.F.; FRY, R.C.; WANG, T.C.; FOX, J.G. 17ßestradiol and tamoxifen prevent gastric cancer by modulating leukocyte recruitment and oncogenic pathways in Helicobacter pylori-infected INS-GAS male mice. Cancer Prev. Res., v. 4, p. 1426-1435, 2011.

SHENKAR, R.; COULSON, W. F.; ABRAHAM, E. Hemorrhage and resuscitation induce alterations in cytokine expression and the development of acute lung injury. Am. J. Resp. Cell. Mol. Biol., v. 10, p. 290-297, 1994.

SINGH, A.; PARKASH, S.; GUPTA, S. K.; SONI, R. K. Severe varicela pneumonia in adults: seven years'single-center experience from India. Indian Journal Critical Care Medicine, v. 22, p. 162-167, 2018.

SITUMORANG, G. R.; SHREERIN, N. S. Ischemia reperfusion injury: mechanisms of progression to chronic grft dysfunction. Pediatry Nephrology, 2018. (ahead of print)

SNELL, R. S. Anatomia. $2^{\underline{a}}$ ed. Medsi Editora Médica e Científica Ltda, 1984. 
SOUZA, D.G.; CASSALI, G.D.; POOLE, S.; TEIXEIRA, M.M. Effects of inhibition of PDE4 and TNF-alpha on local and remote injuries following ischaemia and reperfusion injury. Br. J. Pharmacol., v. 134, p. 985-994, 2001.

SOUZA, D.G.; VIEIRA, A.T.; SOARES, A.C.; PINHO, V.; NICOLI, J.R.; VIEIRA, L.Q.; TEIXEIRA, M.M. The essential role of the intestinal microbiota in facilitanting acute inflammatory responses. Journal Immunology, v. 173, p. 4137-4146, 2004.

SPERRY, J. L.; NATHENS, A. B.; FRANKEL, H. L.; VANEK, S. L.; MOORE, E. E.; MAIER, R. V.; MINEI, J. P. Inflammation and the Host Response to Injury Investigators. Characterization of the gender dimorphism after injury and hemorrhagic shock: are hormonal differences responsible? Crit. Care Med., v. 36, p. 1838-1845, 2008.

STURTZEL, C. Endothelial cells. Adv. Experimental Med. Biology, v. 1003, p. 71-91, 2017.

SUKHOTNIK, I.; HELOU, H.; LURIE, M.; KHATEEB, K.; BEJAR, J.; CORAN, A. G.; MOGILNER, J. G.; SHILONI, E. The effect of leptin on intestinal recovery following ischemia-reperfusion injury in a rat. Pediatry Surgery Internacional, v. 23, p. 473478, 2007.

SUZUKI, T.; SHIMIZU, T.; YU, H. P.; HSIEH, Y. C.; CHOUDHRY, M. A.; CHAUDRY, I. H. Salutary effects of 17beta-estradiol on T-cell signaling and cytokine production after trauma-hemorrhage are mediated primarily via estrogen receptoralpha. Am. J. Physiol. Cell Physiol., v. 292, p.103-111, 2007.

TARN, A.C.; LAPWORTH, R. Biochemical analysis of ascitic (peritoneal) fluid: what should we measure? Ann. Clin. Biochem., v. 47, p. 397-407, 2010.

THOMAS, M.R. \& STOREY, R.F. The role of platelets in inflammation. Thromb. Haemost., v. 114(3), p. 449-458, 2015.

THOMAS, P.; PANG, Y.; FILARDO, E. J.; DONG, J. Identity of an estrogen membrane receptor coupled to a $G$ protein in human breast cancer cells. Endocrinology, v. 146, p. 624-632, 2005.

TUO, B.; WEN, G.; WANG, X.; XU, J.; XIE, R.; LIU, X.; DONG, H. Estrogen potentiates prostaglandin $\mathrm{E}_{2}$-stimulated duodenal mucosal $\mathrm{HCO}_{3}{ }^{-}$secretion in mice. Am. J. Physiol. Endocrinol. Metab., v. 303, p. 111-121, 2012.

VAISHNAVI, C. Translocation of gut flora and its role in sepsis. Indian J. Med. Microbiol., v. 31, p. 334-342, 2013.

VOLLMAR, B.; MENGER M. D. Intestinal ischemia/reperfusion: microcirculatory pathology and functional consequences. Arch. Surg., v. 396, p. 13-29, 2011.

WARD, D.T.; LAWSON, S.A.; GALLAGHER, C.M.; CONNER, W.C.; SHEADONOHUE, T. Sustained nitric oxide production via L-arginine administration ameliorates effects of intestinal ischemia-reperfusion. J Surg Res., v. 89, n. 1, p. 1319, 2000. 
WELBORN, M. B.; OLDENBURG, H. S.; HESS, P. J.; HUBER, T. S.; MARTIN, T. D.; RAUWERDA, J. A.; WESDORP, R. I.; ESPAT, N. J.; COPELAND, E. M.; MOLDAWER, L. L.; SEEGER, J. M. The relationship between visceral ischemia, proinflammatory cytokines, and organ injury in patients undergoing thoracoabdominal aortic aneurysm repair. Crit. Care Med., v. 28, p. 3191-3197, 2000.

WIJNEN, M.H.; VADER, H.L.; ROUMEN, R.M. Multi-antioxidant supplementation does not prevent an increase in gut permeability after lower torso ischemia and reperfusion in humans. Europ. Surg. Res., v. 34, n. 4, p. 300-305, 2002.

WU, H. C.; TUO, B. G.; WU, W. M.; GAO, Y.; XU, Q. Q.; ZHAO, K. Prevalence of peptic ulcer in dyspeptic patients and the influence of age, sex, and Helicobacter pylori infection. Dig. Dis. Sci., v. 53, p. 2650-2656, 2008.

XIAO, X.; LIU, D.; ZHENG, S.; FU, J; ZHANG, H; CHEN, L. Protective effect of estrogen on intestinal ischemia-reperfusion injury in pubertal rats. J. Ped. Surg., v. 39, n. 12 , p. 1828-1831, 2004

XU, D.Z.; ZAETS, S.B.; CHEN, R.; LU, Q.; RAJAN, H.; YANG, X.; ZHANG, J.; FEKETOVA, E.; BOGDAN, N.; DEITCH, E.A.; Cao, Y. Elimination of C5AR prevents intestinal mucosal damage and attenuates neutrophil infiltration in local and remote organs. Shock, v. 31, n. 5, p. 493-499, 2009.

YANG, D. J.; ZHU, Z. X.; U, H. B.; YAN, R. L.; CHEN, J.; CHENG, Y. J.; CAI, Q. P.; WANG, Q. Hypertonic saline activates CD4+ and CD8+ T-lymphocytes in the small intestine to alleviate intestinal ischemia-reperfusion injury. European Review Medical Pharmacology Science, v. 18, p. 3069-3075, 2014.

YANG, H.; JIN, Y.; LI, M.; WANG, C.H.; TANG, C.W. Disturbances of mesenteric lymph flow and in vivo intestinal lymphocyte trafficking during early gut injury induced by ischemia-reperfusion in rats. Lymphology, v. 45, p. 130-139, 2012.

YAO, Y.M.; SHENG, Z.Y.; YU, Y.; TIAN, H.M.; WANG, Y.P.; LU, L.R.; XU, S.H. The potential etiologic role of tumor necrosis factor in mediating multiple organ dysfunction in rats following intestinal ischemia-reperfusion injury. Resuscitation, v. 2, p. 157-168, 1995.

YU, H.P.; SHIMIZU, T.; HSIEH, Y.C.; SUZUKI, T.; CHOUDHRY, M.A.; SCHWACHA, M.G.; CHAUDRY, I.H. Tissue-specific expression of estrogen receptors and their role in the regulation of neutrophil infiltration in various organs following trauma-hemorrhage. J. Leukoc. Biol., v. 79, p. 963-970, 2006.

ZHANG, M.; AUSTEN W. G. JR; CHIU, I.; ALICOT, E. M.; HUNG, R.; MA, M.; VERNA, N.; XU, M.; HECHTMAN, H. B.; MOORE, F. D. JR; CARROLL, M. C. Identification of a specific self-reactive $\operatorname{lgM}$ antibody that initiates intestinal ischemia/reperfusion injury. Proc. Natl. Academy Science US, v. 101, p. 3886-3891, 2004.

ZHOU, T.; PRATHER, E.R.; GARRISON, D.E.; ZOU, L. Interplay between ROS and antioxidants during ischemia-reperfusion injuries in cardiac and skeletal muscle. Int. J. Molecular Science, v. 19, 2018. 